\title{
WestVirginiaUniversity
}

THE RESEARCH REPOSITORY @ WVU

Graduate Theses, Dissertations, and Problem Reports

2020

\section{Joby Talbot's Path of Miracles: Musical and Dramatic Analysis}

Joseph Stuligross

West Virginia University, js0173@mix.wvu.edu

Follow this and additional works at: https://researchrepository.wvu.edu/etd

Part of the Musicology Commons, Music Performance Commons, and the Music Theory Commons

\section{Recommended Citation}

Stuligross, Joseph, "Joby Talbot's Path of Miracles: Musical and Dramatic Analysis" (2020). Graduate Theses, Dissertations, and Problem Reports. 7793.

https://researchrepository.wvu.edu/etd/7793

This Dissertation is protected by copyright and/or related rights. It has been brought to you by the The Research Repository @ WVU with permission from the rights-holder(s). You are free to use this Dissertation in any way that is permitted by the copyright and related rights legislation that applies to your use. For other uses you must obtain permission from the rights-holder(s) directly, unless additional rights are indicated by a Creative Commons license in the record and/ or on the work itself. This Dissertation has been accepted for inclusion in WVU Graduate Theses, Dissertations, and Problem Reports collection by an authorized administrator of The Research Repository @ WVU.

For more information, please contact researchrepository@mail.wvu.edu. 


\title{
Joby Talbot's Path of Miracles: Musical and Dramatic Analysis
}

\author{
Joseph Stuligross
}

Research Project submitted to the

College of Creative Arts at

West Virginia University

in partial fulfillment of the requirements for the degree of

Doctor of Musical Arts in Conducting

Mitchell Arnold, D.M.A, Chair

Kym Scott, D.M.A.

Hope Koehler, D.M.A.

Beth Royall, M.L.I.S., M.M.

Andrew Kohn, Ph.D., Research Advisor

Morgantown, West Virginia

2020

Keywords: Joby Talbot, Path of Miracles, Choral Music, Camino de Santiago

Copyright 2020 Joseph Stuligross 


\title{
ABSTRACT \\ Joby Talbot's Path of Miracles: Musical and Dramatic Analysis
}

\author{
Joseph Stuligross
}

This project investigates Joby Talbot's choral composition Path of Miracles, focusing on interpretive insight as well as musical and extra-musical understandings related to the subject matter, the pilgrimage to Santiago de Compostela in Spain known as the Camino de Santiago. It explores the sources and methods of generating dramatic intensity and seeks to understand how the composer achieved particular dramatic effects. The project proceeds along two related modes of inquiry. The first involves musical evaluation, particularly of pitch, motive, harmony and rhythm techniques, in a somewhat traditional analysis. The second investigates the ways in which musical techniques generate the dramatic and psychological character of the moment. This approach involves understanding the texts and their background (as some are not readily comprehensible at surface level) and evaluates them in the context of particular musical passages. Specifically, this study scrutinizes the use of additive compositional techniques and seek to determine how important dramatic and emotional moments are created. Much of the composition is episodic, with musical materials determined by the dramatic requirements. As a result, form and musical structure are not a focus of this project, although there are some significant formal elements, such as multiple recurrences of the Pilgrims' Hymn, which occur for dramatic reasons. In addition, practical questions about selecting singers and performance venue, as well as other performance-related issues that this piece presents are addressed. 


\section{$\underline{\text { ACKNOWLEDGEMENTS }}$}

I thank my research advisor, Dr. Andrew Kohn, for his tireless assistance, thoughtful and probing suggestions and patience as I worked through the many issues involved in completing this project. I have attempted, with greater and lesser success, to incorporate these ideas and observations throughout the document. I also thank the other members of my committee for their

time and care in review of this document. In particular, I thank Dr. Mitchell Arnold and Dr. Kym Scott, who were instrumental at early stages of this process in helping me to evaluate and understand the implications of particular research possibilities; Dr. Hope Koehler, whose insights into the nature of singers and voices, particularly with respect to varying national schools, was helpful in understanding how performance of a piece such as the one that is the subject of this project can best be performed; and Professor Beth Royall, whose bibliographic assistance has been tremendously helpful. I am thankful to scholars Dr. Maryjane Dunn and Dr. Jessica Knauss, who helped me to navigate and understand some of the obscure textual references in Path of Miracles.

Most importantly, I thank my eternal love, Deb Sadowski, for her bountiful patience and frequent encouragement as well as her direct assistance with many of the technical (and technological) requirements of this project. Her skills and generosity know no bounds. And I finally thank my three children, Clara, Ben Caroline and especially Jacob (who, in addition to solving a tricky technological issue, was incredibly good-natured and tolerant as our socialdistanced household attempted to retain our joyful exuberance). 


\section{TABLE OF CONTENTS}

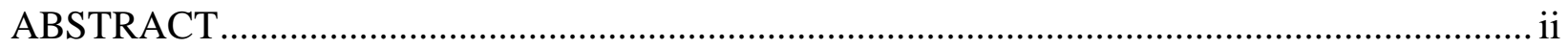

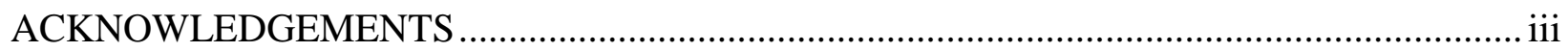

LIST OF FIGURES ……………………………….......................................................... vi

CHAPTER 1: INTRODUCTION AND BACKGROUND TO POM AS A DRAMATIC WORK

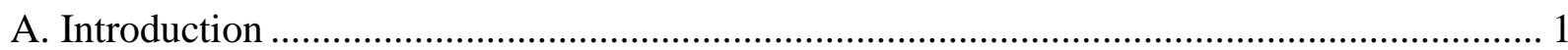

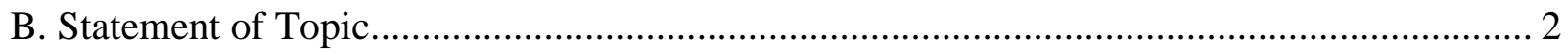

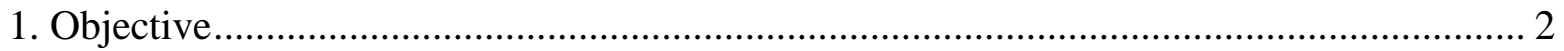

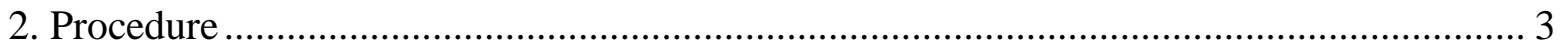

3. Need for Study and Review of Sources ........................................................................ 4

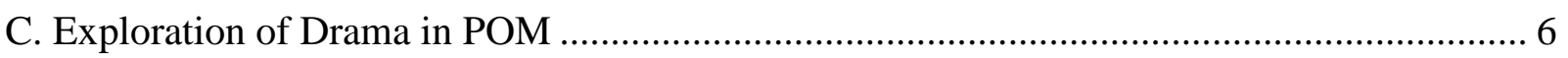

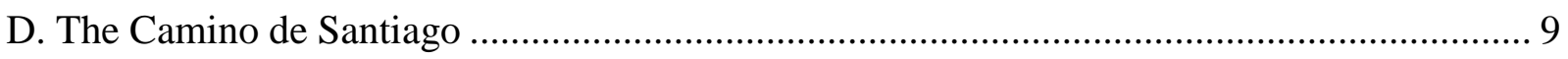

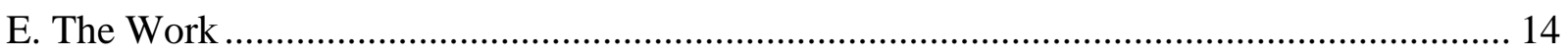

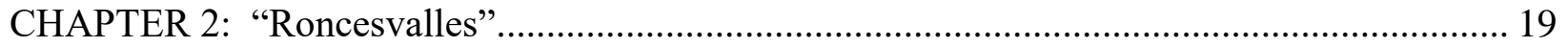

A. Pasiputput Opening …………………………………................................................. 19

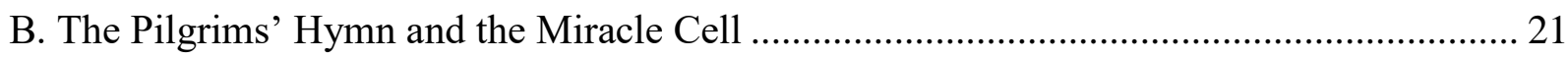

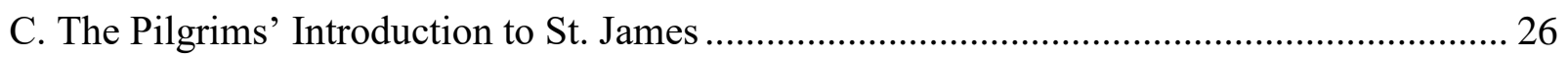

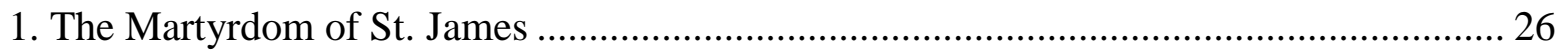

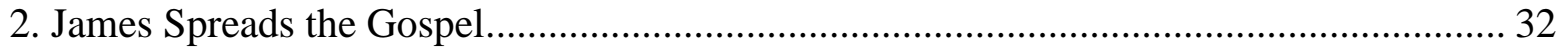

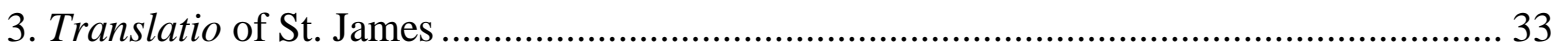

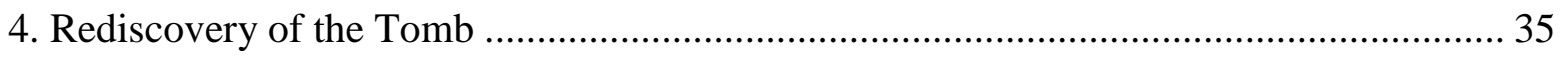

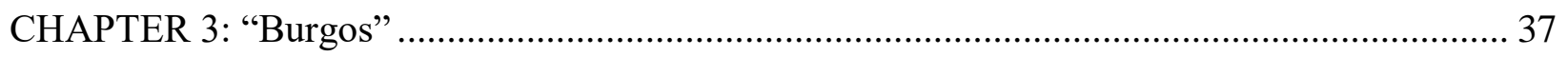

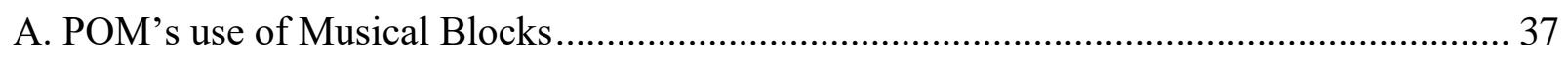

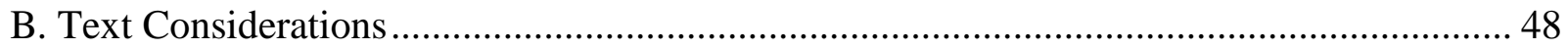

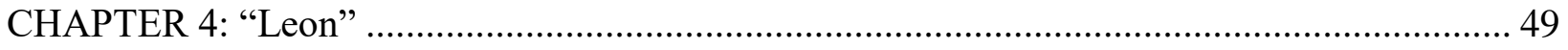

A. Musical Depictions of Light....................................................................................... 49

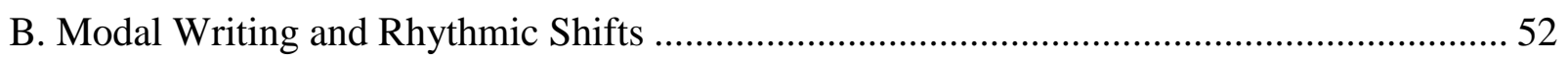

C. Shifting Halo and Tertiary Harmonic Motion ................................................................. 56

D. Arrival at Eb Major and Return of the Canon: Transposition Technique ............................. 58

E. The Shift to Lydian Mode and Half-Step Modulation from Db to D Major .......................... 60

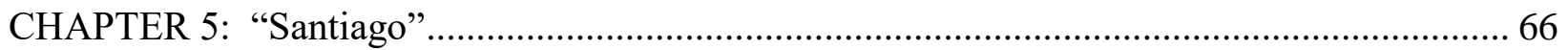




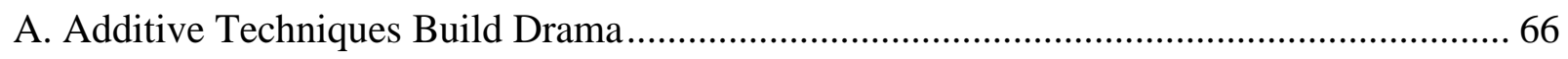

B. Approaching Monte de Gozo and Descent to Santiago........................................................ 71

C. Return of the Pilgrims' Hymn and Conclusion ................................................................ 77

CHAPTER 6: PERFORMANCE PLANNING AND PRACTICAL OBSERVATIONS FOR

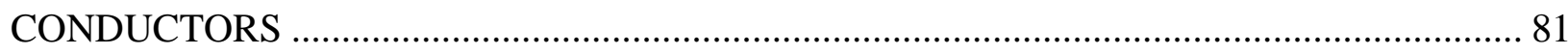

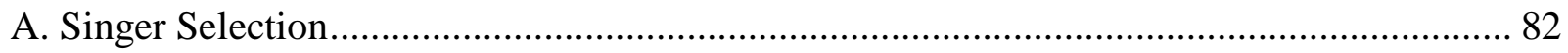

B. Venue and other Programming Considerations................................................................. 83

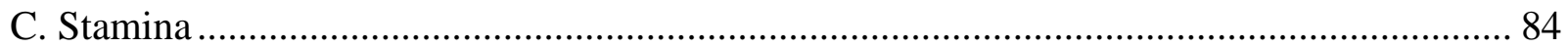

D. Interpretation: Rhythm, Ancient Musical Styles and Tuning............................................... 87

CHAPTER 7: CONCLUSION: POM AS A DRAMATIC WORK ……….................................. 91

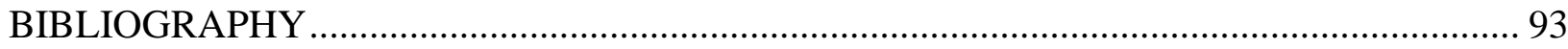

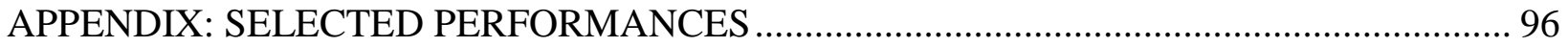




\section{LIST OF FIGURES}

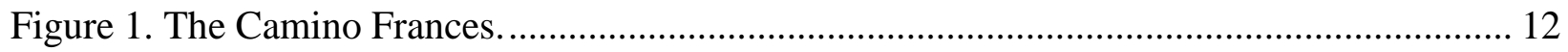

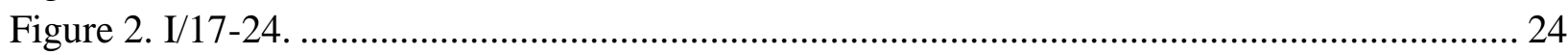

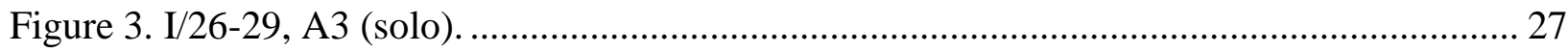

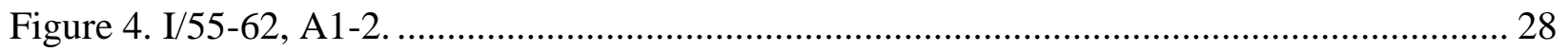

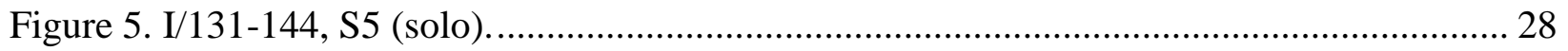

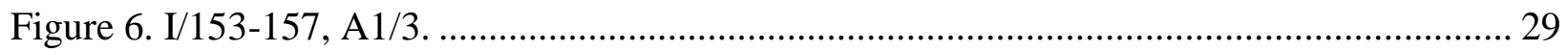

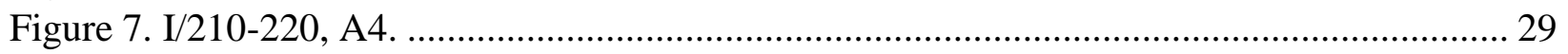

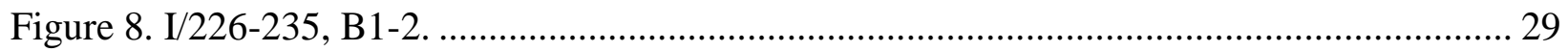

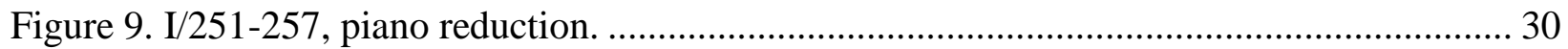

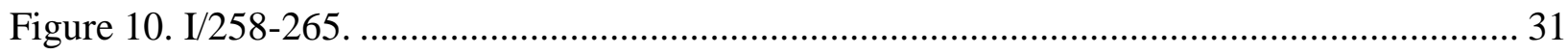

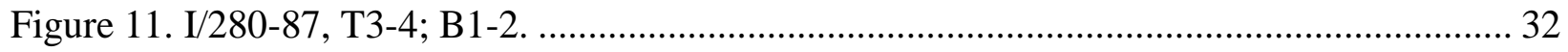

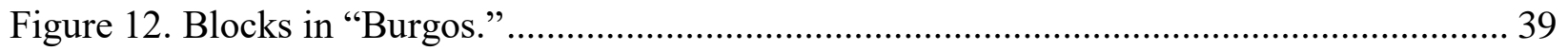

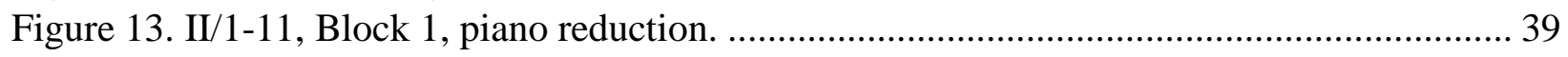

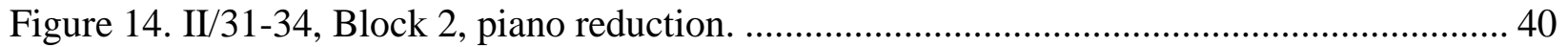

Figure 15. II/80-86, T, B, Block 3, piano reduction. ....................................................... 40

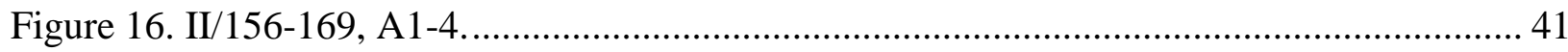

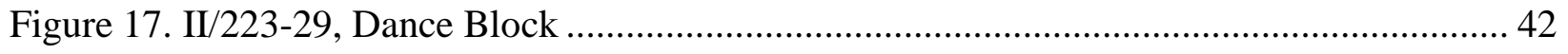

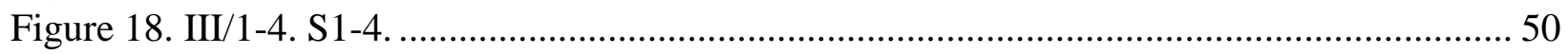

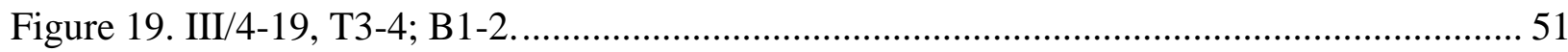

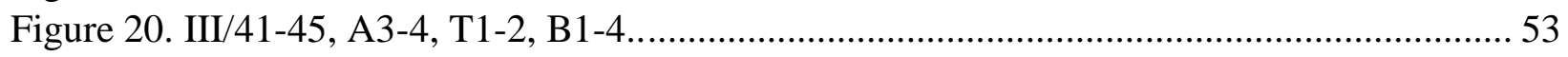

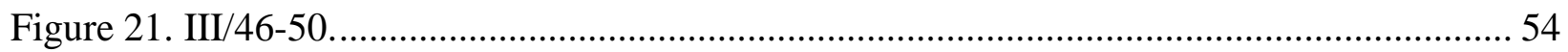

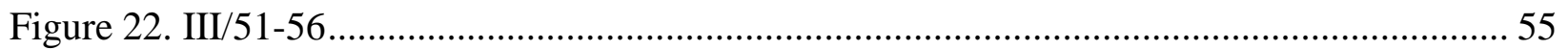

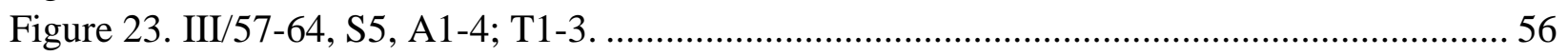

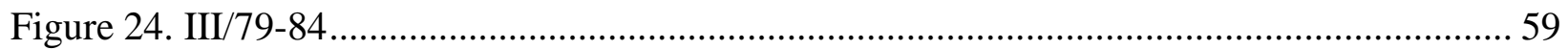

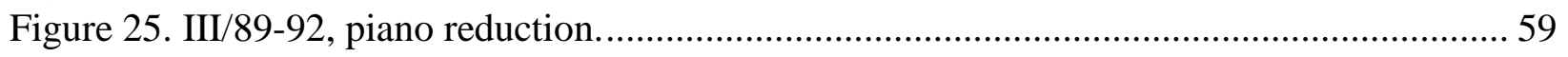

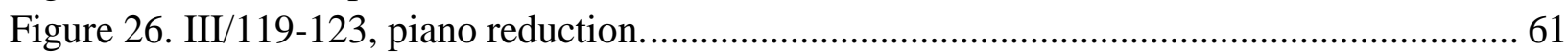

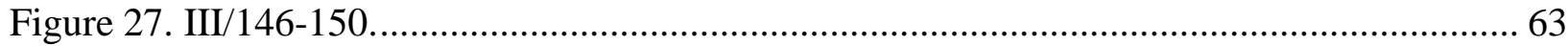

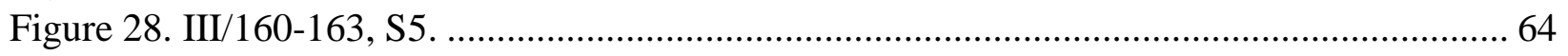

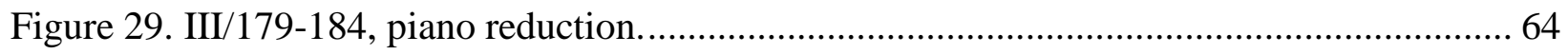

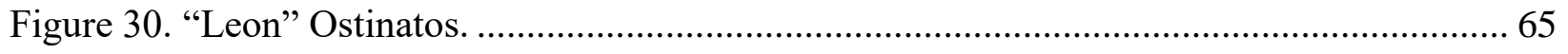

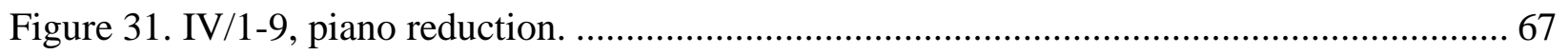

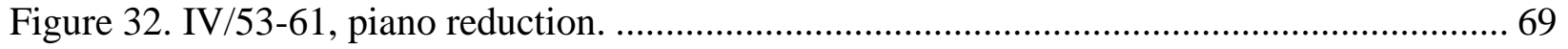

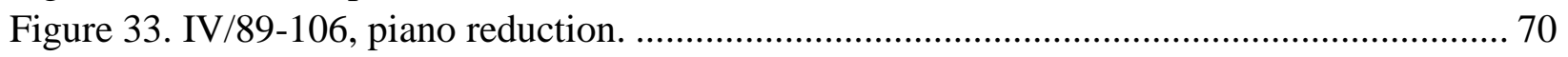

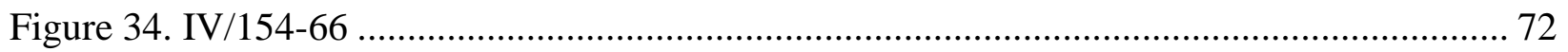

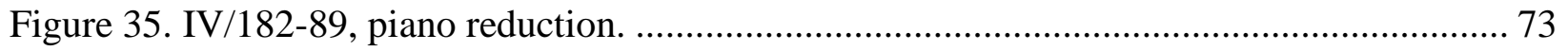

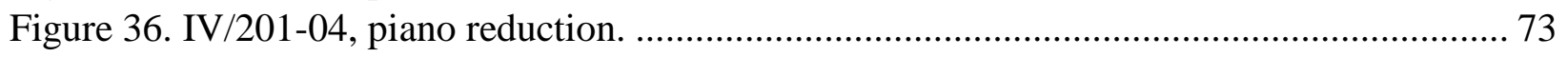

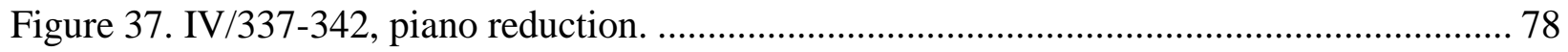

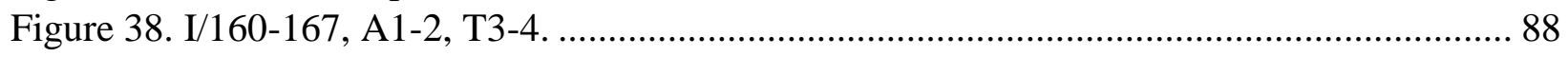




\section{CHAPTER 1: INTRODUCTION AND BACKGROUND TO POM AS A DRAMATIC WORK}

\section{A. Introduction}

Joby Talbot's Path of Miracles (POM) has generated considerable excitement since its premiere in 2005. The work was commissioned by the British choral ensemble Tenebrae and premiered at the City of London Festival, conducted by Nigel Short and directed by Ceri Sherlock. ${ }^{1}$ Since then, it has been recorded in two full-length commercial CD recordings and has been performed all over the world. ${ }^{2}$ Choral works rarely have stage directions, but this one has minimal "suggested" directions for singer movement and location during performance. At the premiere singers wore draped purple robes and made full use of the performing space, moving at various points to choir stalls beneath the organ loft, up to the gallery and before the altar, as well as dispersing generally throughout the church at the final chanting exit. ${ }^{3}$ Subsequent productions have also incorporated theatrical gestures, often taking advantage of unique circumstances in the performing venue, and some have added costumes, slides, balletic choreography by professional dancers and even transport of both audience and musicians to varying locations. ${ }^{4}$ Performers have readily grasped the dramatic potential of the work.

\footnotetext{
${ }^{1}$ Tenebrae and Nigel Short, Joby Talbot: Path of Miracles, CD Recording (London: Signum Records, Ltd. SIGCD078, 2006), liner notes by Gabriel Crouch, and including "A Note by Joby Talbot".

${ }^{2}$ Tenebrae cut the first recording at the time of the premier. Tenebrae and Short. Conspirare, based in Austin, Texas, made a second recording in 2015 on the Harmonia Mundi label [HMU 807603], conducted by Craig Hella Johnson; see Kathryn Longo, review of Joby Talbot: Path of Miracles, by Craig Hella Johnson, The Choral Journal 56, no. 11 (July 2016): 79. Tenebrae has since re-released its 2005 recording. For a selected list of ensembles which have performed POM, see the Appendix.

${ }^{3}$ Nick Breckenfield, "Joby Talbot - Path of Miracles," Classical Source, accessed March 12, 2020, classicalsource.com/db_control/db_concert_review.php?id=2743.

${ }^{4}$ See reviews of Westminster Choir, ODC Dance and The Crossing in the Appendix for descriptions.
} 
POM has been highly respected by other composers. In a survey of prominent contemporary choral composers ${ }^{5}$ asked to name works that will still be performed 100 years from now, Abbie Betinis named POM, and valued especially its "great storytelling" and the way it invites an audience on a journey and engages all the way through, including, she emphasized, "the way it leav[es] a lot of space - silence even - for the listener to imagine." Similarly, Jake Runestad admired POM's “evocative musical language and masterful, orchestral-like writing" and its "powerful narrative." Runestad emphasized the way POM "speaks to the compelling human desire for personal transformation through a physically and emotionally exhausting journey."

\section{B. Statement of Topic}

\section{Objective}

This project investigates POM focusing on interpretive insight as well as musical and extra-musical understandings related to the subject matter, the pilgrimage to Santiago de Compostela in Spain known as the Camino de Santiago. It explores the sources and methods of generating dramatic intensity and seeks to understand how the composer achieved particular dramatic effects. The project proceeds along two related modes of inquiry. The first involves musical evaluation, particularly of POM's use of pitch, motive, harmony and rhythm, in a somewhat traditional analysis. The second investigates the ways in which POM's musical techniques generate the dramatic and psychological character of the moment. This approach involves understanding the texts and their background (some are not readily comprehensible at

\footnotetext{
${ }^{5}$ Alan Denney, "Ours to See: Emerging Trends in Today's Choral Compositions," Choral Journal 60, no. 3 (October 2019): 11-12.

${ }^{6}$ See also Breckenfield, "Path of Miracles Review" (POM "is to the first decade of the 21st century what Arvo Pärt's Passio was twenty years earlier").
} 
surface level). Specifically, this study scrutinizes POM's compositional techniques and seeks to determine how important dramatic and emotional moments are created, given the text and reasonable assumptions about the nature of pilgrimage at each stage of the journey. Notable in this interaction is the manner in which the music generates dramatic elements that enrich or deepen the text. This document thus engages in a hermeneutic exploration of the interplay between pilgrimage, music and text.

Much of the composition is episodic, with musical materials determined by dramatic requirements. As a result, form and musical structure receive scant attention in this project. This is not to deny that significant formal elements are in play, such as multiple recurrences of the Pilgrims' Hymn. It is hoped that interpretation and understanding of the work can be enhanced in a way that should prove useful to conductors, but also to singers, theorists and audiences seeking to gain a deeper understanding of the work.

\section{Procedure}

The POM plot is barebones, but does, in imprecise terms, tell the story of a generic pilgrim's journey along the physical path of the Camino de Santiago, with way-stations at each of four important points: the origin at the Abbey at Roncesvalles and the cathedrals at Burgos, León and Santiago itself, with each way-station a separate movement. One chapter here will be devoted to each movement, with brief additional chapters devoted to a few practical suggestions for conductors, and some concluding thoughts on POM as a dramatic work.

Each chapter focuses on compositional techniques which carry the drama, though time and space will not permit a complete evaluation of all musical elements or even all segments of each movement. Some of the texts are oblique and contain hidden references, both due to the ancient origin of some of the sources and because Talbot (and Robert Dickinson, the librettist) 
have, often for dramatic reasons, obscured meaning at various points. These textual matters are fleshed out in this document in order to enhance an understanding of their relation to the drama of pilgrimage as well as the music itself.

\section{Need for Study and Review of Sources}

POM contains many striking features, including the use of ancient texts, ancient styles of music incorporated into a modern composing idiom, complex rhythmic interactions, interesting voicing, etc. Central to understanding is the score itself, published and readily accessible from Chester Music. ${ }^{7}$ Many of these features have yet to be fully investigated. In particular, no review has been undertaken of the sources and methods of generating dramatic intensity.

To date, two DMA dissertations have studied POM. The first, by Joy Meade in 2016, looks into ideas of pilgrimage and post-minimalism. ${ }^{8}$ Meade examines the ways in which POM evokes a modern-day depiction of the Camino de Santiago, including ways in which sacred and secular elements interact. She offers a firm foundation in the anthropological understandings of "pilgrimage" and describes the physical features of the cathedrals on the route. (Burgos, León and Santiago each have unique architectural features which Meade connects to elements of POM.) She also includes a brief overview of pitch content in a movement-by-movement musical analysis focusing on post-minimalist compositional devices, including repetition, reference and quotation, rhythmic and textual layering, tiered dynamics and phase shifting. Thus, Meade's work forms a critical support for this project's more focused analysis of specific connections between musical techniques and drama.

\footnotetext{
${ }^{7}$ Joby Talbot, Path of Miracles (London: Chester Music, 2005).

${ }^{8}$ Joy Elizabeth Meade, "Pilgrimage and Postminimalism in Joby Talbot's Path of Miracles" (DMA diss., University of Georgia, 2016), athenaeum.libs.uga.edu/handle/10724/36263.
} 
The second dissertation, by Jeffery Goolsby (2018), compares POM with two other recent choral pieces on pilgrimage subjects written by British composers. ${ }^{9}$ Goolsby examines the formal structure of POM, including important tonal schemes and harmonic activity. He examines text settings and programmatic features and evaluates style relative to the compositional language of each piece, drawing connections between the three works. Together, Meade and Goolsby offer significant information about the nature of pilgrimage, its appeal in modern society and its relation to this specific work. By laying a foundation so thoroughly, they make possible a more detailed musical exploration in the current project.

Most useful in understanding the nature of minimalism and its influence on the music of Talbot and others is Jonathan Bernard's article, "The Minimalist Aesthetic in the Plastic Arts and in Music," which provides a strong foundation of both the esthetic and the theoretical aspects of minimalism. ${ }^{10}$ Additional sources are necessary for understanding the texts used in POM and the nature of the pilgrimage that it evokes. Valuable information on the cult of St. James as well as Codex Calixtinus, the $12^{\text {th }}$ century manuscript from which many of the POM texts are drawn, is contained in Paul Helmer's The Mass of St. James: Solemn Mass for the Feast of the Passion of St. James of Compostela according to the Codex Calixtinus. ${ }^{11}$ Also useful for understanding the Codex Calixtinus is The Pilgrim's Guide to Santiago de Compostela, by William Melczer, which

\footnotetext{
${ }^{9}$ Jeffery H Goolsby, “A Pilgrimage Triptych: A Conductor's Guide to Three Contemporary Choral Works" (DMA diss., Texas Tech University, 2018), ttuir.tdl.org/bitstream/handle/2346/82110/Goolsby_DissertationReview.pdf?sequence=8\&isAllowe $\mathrm{d}=\mathrm{y}$, studying POM as well as To the Field of Stars by Gabriel Jackson and Footsteps by Owain Park.

${ }^{10}$ Jonathan W. Bernard, "The Minimalist Aesthetic in the Plastic Arts and in Music," Perspectives of New Music 31, no. 1 (1993): 86, doi.org/10.2307/833043.

${ }^{11}$ Paul Helmer, The Mass of St. James: Solemn Mass for the Feast of the Passion of St. James of Compostela according to the Codex Calixtinus (Ottawa, Canada: Institute of Mediaeval Music, 1988).
} 
translates Book V and includes helpful notes and annotations. ${ }^{12}$ Similarly, Books II and III, which include the Miracles of St. James, have recently been translated and are helpful in understanding some of the references in POM. ${ }^{13}$ A collection of papers on the Codex Calixtinus also contains useful information about the miracles of St. James, the tomb beneath the choir at the Santiago cathedral and the building itself. ${ }^{14}$

Information on the composition of POM and the work itself are contained in two excellent essays, one by Gabriel Crouch, a Tenebrae member, and included in the Tenebrae CD liner notes, and a second by Eric Leibrock, contained in program notes for Conspirare performances. ${ }^{15}$ The Tenebrae CD also contains information about Talbot's research into the project and the selection of texts.

\section{Exploration of Drama in POM}

POM is a choral work with minimal staging, no individual characters and a rather barebones plot. Thus, it may at first seem unusual to speak in terms of drama, which is typically exemplified in music by the operatic genre. However, it is clear, as Donald Grout has observed, that drama in music does not require visual trappings of theatre like scenery, costumes, staging. As an example, "religious dramatic music [knows] such forms as the cantata, the oratorio, and

\footnotetext{
${ }^{12}$ New York: Italica Press, 1993.

13 Thomas F. Coffey and Maryjane Dunn, The Miracles and Translatio of Saint James -- Books Two and Three of the Liber Sancti Jacobi (New York: Italica Press Medieval and Renaissance Texts Series, 2019).

${ }^{14}$ John Williams and Alison Stones, eds., The Codex Calixtinus and the Shrine of St. James, Jakobus-Studien 3 (Tübingen: Narr, 1992).

${ }^{15}$ Gabriel Crouch, Path of Miracles Tenebrae CD Liner Notes (London: Signum Records, Ltd., 2006); Eric Leibrock, "Path of Miracles Program Booklet, Conspirare," January 2014, conspirare.org/wp-content/uploads/path-of-miracles-program-booklet.pdf.
} 
the Passion." ${ }^{16}$ The key for Grout is what he refers to as "the dramatic impulse." ${ }^{17}$ Similarly, Joseph Kerman in his classic work Opera as Drama, explains that "drama is not, exclusively, a matter of the effective deployment of plot." ${ }^{18}$ Nor, Kerman continues, does it mean "photographic reproduction" of an action, character, locale, etc. Instead, Kerman views drama in music as akin to drama in poetry and concludes: "in each form, drama is articulated on its most serious level by an imaginative medium, poetry in the one case, music in the other." ${ }^{19}$

Kerman notes T.S. Eliot's observation that dramatic poetry is adequate to express "the nameable, classifiable emotions and motives of our conscious life when directed towards action" but that there is, in addition, a "fringe of feeling" which dramatic poetry can express "at its moments of greatest intensity." In those moments, "we touch the border of those feelings which only music can express." 20

While Grout and Kerman, eminent authorities, were both reluctant to stake a precise claim for the meaning of "drama" (Kerman objecting that answers to the question have been "general" and "all necessarily partial"), ${ }^{21}$ I shall happily rely on Eliot's, and take as "drama" an artwork that expresses "nameable" emotions and motives that are "directed towards action." This document investigates the ways in which POM engages in that particular form of expression and pays particular attention to the work's ability to express Eliot's "fringe," interpreted here to mean the expression of subtle and changing emotions as well as psychological motivations. In POM,

\footnotetext{
${ }^{16}$ Donald Jay Grout, A Short History of Opera, 3rd Edition (New York: Columbia University Press, 1988), 1.

${ }^{17}$ Grout, 1.

${ }^{18}$ Joseph Kerman, Opera as Drama (New York: Alfred A. Knopf, 1956), 7.

${ }^{19}$ Kerman, 8.

${ }^{20}$ Kerman, 8-9, quoting T. S. Eliot, Poetry and Drama (Cambridge, Mass.: Harvard University Press, 1951).

${ }^{21}$ Kerman, 7.
} 
these derive from minimal and sometimes ambiguous action, but nonetheless that action is the starting point for the musical construction. An underpinning of this study is that the techniques, methods, and values of other dramatic art forms can readily be brought to bear in exploring meaning in POM.

POM is a dramatic work, and in that sense could be considered like an opera, but one stripped to its essentials. The mundanity of the journey, the mechanics of lodging, etc., appear to a surprising extent, but only in ways that pierce the pilgrim's emotional state. The "real world" is transported to an artistic realm, from the first note to the last. Concrete events do not occur, nor do individual characters serve as vessels for particular emotional or expressive objectives. While there are occasional solo voices, they cannot be called individuals, but remain faceless, personality-less creatures reminiscent of those in Meredith Monk’s Dolmen Music (1981). ${ }^{22}$ On this journey, pilgrims seek to avoid ego or personality, instead joining with their fellows in their shared struggles.

This is worked out in both outward ways, which are often communal, and inward ways, which are often psychological or spiritual. Like the turba choruses of a more traditional work, e.g., the St. Matthew Passion, POM sometimes contains communal or unified expressions of the group. And yet a pilgrimage is also a highly personal experience that one undertakes alone. ${ }^{23}$ The inward journey is just as important as the physical one, and POM tells that story as well,

\footnotetext{
${ }^{22}$ Meredith Monk, "Monk: Dolmen Music,” Youtube, July 29, 2018, youtube.com/watch?v=DVrsuMWX7-Y.

23 "For many, Catholics and dissenters alike, the journey represents a confrontation with personal identity and spirituality. People with questions about life find that this lengthy, exhausting route provides them with an opportunity for self-discovery, reflection, transformation, and purification." Walter Van Herck, "Pilgrimages: Being on and off the Right Track," in Sacred Places: Pilgrimages in Judaism, Christianity and Islam, ed. Chris de Lauwer (Antwerp: BAI for the Museum aan de Stroom, 2014), 16; quoted in Meade, "Pilgrimage and Postminimalism in POM," 18-19.
} 
expressing a progression of psychological and emotional states. All of these experiences, whether inner or outer, have an impersonal tone, applicable to any and every pilgrim. We have mostly generalities as to external action - rumors and ambiguous references to experiences (e.g., "Innkeepers cheat us"). These are often quite vague - e.g., did they really cheat us, or did they cheat some other pilgrims in the distant past? POM thus presents singers as totems or icons perhaps representing a "typical" pilgrim, keeping in mind that the pilgrim could be from any time period (the period is left intentionally vague).

At its root, POM generates a plot encompassing a journey, both physical and psychological or spiritual, both corporate and personal. And, to use Eliot's terms, POM expresses emotions and motives that are directed toward that action, specifically, a pilgrimage along the Camino de Santiago. In this way, POM can be effectively understood as a dramatic work. ${ }^{24}$ Moreover, musical expression of this plot fulfills exactly the same role as it does in opera and it is therefore possible to investigate the ways that music serves to give meaning to POM. In fact, perhaps because the plot is so bare, music plays a vital role in providing meaning.

\section{The Camino de Santiago}

The Camino de Santiago, or "Way of St. James," is an ancient Christian pilgrimage which culminates at the cathedral of St. James in Santiago de Compostela. Santiago de Compostela is the capital of Galicia at the northwest corner of Spain, directly north of Portugal. The name derives from Latin, Sanctus Iacobus, "Saint James," and Campus stellae, "Field of Stars," perhaps referring to the field whose brilliant light is reputed to have guided the rediscovery of James's body in the $9^{\text {th }}$ century.

\footnotetext{
24 Thus, composer Jake Runestad has admired the work's "powerful narrative.” Denney, "Emerging Trends," 11.
} 
The cathedral, which is thought to hold the body of St. James, is one of the revered "thin places" in the world, where the distance between heaven and earth is at its most narrow. Pilgrims have for more than a thousand years made the trek to visit this special place. ${ }^{25}$ Indeed, the earliest "tour book" is nearly that old. The $12^{\text {th }}$ century Codex Calixtinus, in its Book IV, contains a "Pilgrims' Guide" setting forth sites to see, recommendations and warnings about potential pitfalls on the journey. ${ }^{26}$

St. James was one of the apostles of Jesus, son of Zebedee (and possibly also of Salome) and brother of John. He is mentioned only sporadically in the Bible, most usually in the company of his brother. James was present at some of Jesus's most transcendental moments, including the Transfiguration, his raising of Jairus's daughter, and his anguish at the Garden of Gesthemane. Jesus named James and John both as Boanerges, or "Sons of Thunder," and their fierceness was recorded in the Bible. ${ }^{27}$ James is instructed by Jesus in lessons of humility on more than one occasion, as when James asks that he be allowed to call down a fire of terror on a Samaritan village. ${ }^{28} \mathrm{He}$ was the first apostle to be martyred, beheaded by Herod Agrippa I in $44 \mathrm{CE} .{ }^{29}$

Although James became patron saint of Spain, his presence there is something of a mystery. The earliest texts contain no mention of James on the Iberian Peninsula. Only in the

${ }^{25}$ Leibrock, "Path of Miracles Program Booklet, Conspirare," 6. As early as 950, Hugh of Godescalc, bishop of Le Puy visited St. James' shrine, along with 200 monks. Helmer, Mass of St. James, 14. Chaucer saw pilgrimage, including the journey through "Galice" to "seynt Jame," as an entirely natural practice, like sap running in spring. Quoted in Helmer, 13.

${ }^{26}$ Helmer, Mass of St. James, 22.

${ }^{27}$ Melczer, The Pilgrim's Guide to Santiago de Compostela, 7.

${ }^{28}$ Luke 9:51-56. More detailed accounts of James' preaching and the origins of his cult are in Coffey and Dunn, Miracles and Translatio, XXIII-XXVIII. See also Melczer, The Pilgrim's Guide to Santiago de Compostela, 7-13.

${ }^{29}$ Acts 12:1-2. This passage is prominent in POM. 
seventh century is he directly associated with preaching in Spain. The Breviarium apostolorum, quoted in POM, describes James's burial in exceedingly sparse and ambiguous terms. ${ }^{30}$

Pilgrims follow a truly ancient path, portions of which still run along ancient Roman roads built at the height of the empire. The Camino has a long history as a pilgrimage route but also played a prominent role in historical events of northern Spain. It was used by the Romans to administer its far-flung outposts, the Moors in traversing the countryside and Charlemagne centuries later in his resurgent battles to drive out the Moors. ${ }^{31}$ Today the Camino is used by thousands of pilgrims, who come from all over the world. The Camino has experienced a tremendous resurgence over the past decades. The number of pilgrims visiting Santiago de Compostela rose from a few hundred in the 1970 s to 23,218 in 1996, increasing to 100,377 in 2006 and 278,232 in $2016 .^{32}$

Historically, pilgrimages were undertaken in a spiritual quest for salvation, or to fulfill a promise or to seek a special favor. Some pilgrims travel in order to perform a devotional act or for the specific purpose of worshiping in the presence of the tomb of St. James. ${ }^{33}$ In modern times, specific religious purposes have given way somewhat to those traveling for purposes of “exercise, adventure, curiosity, study, spiritual growth, self-exploration," or just an inexpensive vacation. ${ }^{34}$ They follow one of several routes. At least four separate routes led across modern day

\footnotetext{
${ }^{30}$ Additional sources for the early development of James' cult and connections with the Iberian Peninsula are in Coffey and Dunn, Miracles and Translatio, XXVIII.

${ }^{31}$ Crouch, POM CD Liner Notes, 2. Book IV of the Codex Calixtinus contains an early variant of the Song of Roland, and describes Charlemagne's and Roland's battles against the Moors, including Charlemagne's vision of St. James inspiring him to action. Coffey and Dunn, Miracles and Translatio, XVI, XXXVIII.

${ }^{32}$ Coffey and Dunn, Miracles and Translatio, XI.

${ }^{33}$ Coffey and Dunn, XI.

${ }^{34}$ Coffey and Dunn, XI. In recognition of these new secular objectives, the governmental Pilgrim's Office has for the last several decades offered a certificate of welcome to pilgrims who
} 
France and into Spain from as far away as Paris. ${ }^{35}$ The Camino Frances, or French Route, starts at the abbey of Roncesvalles, at the foot of the Pyrenees near the French border (Fig. 1). From here it affords stops at the cathedrals of Burgos and León before arriving at Santiago.

Figure 1. The Camino Frances. ${ }^{36}$

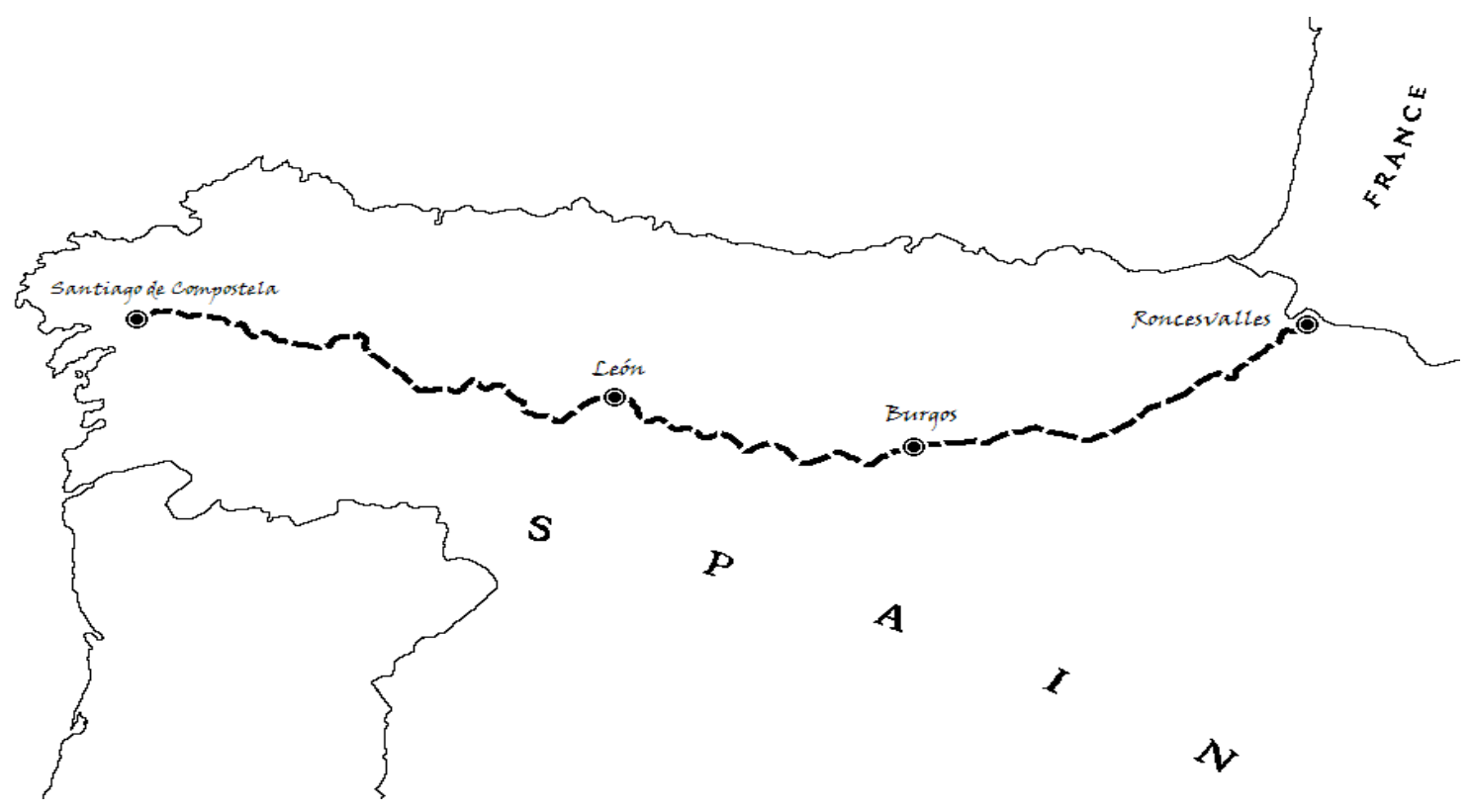

Upon reaching Galicia, more organized support for pilgrims exists. Pilgrims carry a special credential with them, which is stamped at various points along the Camino. Pilgrims seeking the official "Compostela," or certificate of completion, must collect at least two stamps

do not declare a religious or spiritual foundation for their travel (required in order to receive the Compostela certifying completion).

${ }^{35}$ The four main routes, from Paris, Vezelay, Le Puy and Arles, are described in the Codex Calixtinus. Helmer, Mass of St. James, 17.

${ }^{36}$ Debra Shearer-Dirié, "Fusion Vocal Ensemble Program, Path of Miracles," April 2017, 1, fusionvocalensemble.org/uploads/2/1/2/1/21215054/fusion_programme_path_of_miracles_marc h-april_2017.pdf. 
per day and travel at least $100 \mathrm{~km}$ (more if not traveling on foot). A series of hostels provide discounted accommodations. ${ }^{37}$

The pilgrimage officially ends at Santiago de Compostela, but many continue all the way to the coast at Finisterre which at one point was believed to be the literal end of the earth. According to tradition, pilgrims burn an article of clothing in a symbolic shedding of past life. ${ }^{38}$ Those making this additional journey can earn a distinct credential provided by the local government (Concello de Negreira). ${ }^{39}$

Many pilgrims write blogs, take photos, stop at local pubs and restaurants, post to social media and generally participate in modern forms of documentation, reflection and communication, in addition to traditional prayer and masses held regularly along the route. ${ }^{40}$ Thus, the Camino de Santiago is not totally removed from the mechanics of daily life. It enables the pilgrim to escape certain elements, but materialistic concerns of food, lodging, etc., must still be addressed. In fact, some of the hardships involved in navigating these matters, in addition to the physical challenge of travelling hundreds of miles on foot, is part of the process of transformation potentially offered to pilgrims. Converting a modern day travel experience with such a variety of elements into something mystical and reverent requires independent spiritual preparation by the pilgrim and converting it into an artful and expressively inspirational concert performance requires special consideration by the composer.

\footnotetext{
${ }^{37}$ Coffey and Dunn, Miracles and Translatio, XIII.

${ }^{38}$ Crouch, POM CD Liner Notes, 4.

${ }^{39}$ Coffey and Dunn, Miracles and Translatio, XII.

${ }^{40}$ Coffey and Dunn, XIV.
} 


\section{E. The Work}

Composer Talbot was born in 1971 and is best known for dramatic and theatrical works, including TV and film scores (Hitchhiker's Guide to the Galaxy, 2005), as well as narrative ballets (e.g., The Winter's Tale, 2014) and a recent opera premiered by the Dallas Opera (Everest, 2015). ${ }^{41}$ He has only one other choral work, a short piece premiered by the King's Singers. ${ }^{42}$ POM is written in seventeen separate voices, with occasional crotales (small, pitched cymbals) and temple bells. The music is almost entirely a cappella and tests the extremes of vocal range for all of the voice parts. As a result it is challenging to perform and has mostly been attempted by professional or conservatory ensembles.

In preparation for his creative work on POM, Talbot and his family spent 10 days on the Camino, visiting important cathedrals and experiencing pilgrimage first-hand. ${ }^{43}$ One indication of the closeness with which the piece is tied to a particular place and the Camino itself is the premiering ensemble's original intention to perform respective movements in Spain in each of these four cities and then the entire piece at the cathedral at Santiago de Compostela. ${ }^{44}$

The text by Dickinson (b. 1962) includes quotations from the Bible and from a variety of medieval sources, principally those which refer to St. James. These include the Codex Calixtinus, which contains important sources of early music as well as the Pilgrims' Guide. The Codex also includes a description of the 22 miracles of St. James as well as Jamesian liturgical celebrations. It is called Codex Calixtinus because it is claimed on the inscription, and throughout the text, as

\footnotetext{
${ }^{41}$ Joby Talbot, "About," Joby Talbot, accessed March 23, 2020, jobytalbot.com/about. 42 “The Wishing Tree.” Joby Talbot, “Selected Works,” Joby Talbot, accessed March 25, 2020, jobytalbot.com/works.

43 Talbot, "From the Composer," in Leibrock, "Path of Miracles Program Booklet, Conspirare," 5.

${ }^{44}$ Breckenfield, "Path of Miracles Review."
} 
the work of Pope Calixtus II, who was pope from 1119 to 1124. Scholars agree, however, that Calixtus was not the author. ${ }^{45}$ Codex Calixtinus is preserved in the cathedral archives at Santiago. ${ }^{46}$ The cathedral itself was built during the $12^{\text {th }}$ century and consecrated in $1211 .^{47}$

According to the Pilgrims' Guide, construction began in 1078 and was completed 44 years later (1122). ${ }^{48}$ However, abundant historical and archaeological evidence makes clear that construction was halted during the 1120 s with significant parts of the nave and the west façade left unfinished. ${ }^{49}$ It was only in the 1160 s, when, due to political changes Santiago again became an important center, that construction resumed and the structure was completed. ${ }^{50}$

POM also includes texts from a variety of other ancient sources:

- Breviarium apostolorum, an $8^{\text {th }}$ century history of the lives of the apostles;

- Miragres de Santiago, a primary source of medieval Jacobean culture;

- Martyrology of Floro de Lyon, a $9^{\text {th }}$ century manuscript;

- Legenda, or "Golden Legend," written around 1260 by the Genoese Dominican monk Jacques de Voragine and which describes St. James's life in Spain; and

- Carmina burana, a manuscript of poems and dramatic texts created c. 1230, only a few years later than the Codex Calixtinus. ${ }^{51}$

\footnotetext{
${ }^{45}$ Williams and Stones, Codex Calixtinus and the Shrine of St. James. The compilation date of the Codex Calixtinus is not precise, but certainly occurred during the mid- $12^{\text {th }}$ century. The manuscript contains the Liber Sancti Iacobi (LSI), the "Book of St. James," a series of texts related to the apostle James. The LSI is to be distinguished from the Codex Calixtinus as the LSI represents the archetype from which Codex Calixtinus was created. Other versions of the LSI, none as complete as Codex Calixtinus, have also been found.

${ }^{46}$ Williams and Stones, ix.

${ }^{47}$ Helmer, Mass of St. James, 15.

48 James D'Emilio, "The Building and the Pilgrims' Guide," in The Codex Calixtinus and the Shrine of St. James, ed. John Williams and Alison Stones (Tübingen: Narr, 1992), 185.

${ }^{49}$ D'Emilio, 185.

${ }^{50}$ D'Emilio, 185.

${ }^{51}$ Crouch, POM CD Liner Notes, 13. Jack Sage assisted with compiling the ancient texts. Crouch, 5. It is generally accepted that the Floro manuscript was written in the 9th century, the Tenebrae CD liner notes notwithstanding. See, e.g., Francisco Singul, Historia Cultural Do Camiño de Santiago (Vigo, Spain: Editorial Galaxia, 1999), 33.
} 
Style ranges from minimalist repetitive harmonies and rhythmic pulsing to periods of more traditional functional harmony. Much of the harmony is not functional in a common practice period sense, raising the question of how it is that POM is able to evoke significant drama and emotion in the absence of this principle tool. Clearly, POM makes full use of other musical elements to build tension and drama, including texture, voice leading and tessitura. Rhythmically, the music generally maintains a steady pulse (albeit with much tempo variance both between and within movements), but subdivisions of the meter include syncopations and complex layers that interplay with the central pulse, including 4 against 3 and other combinations. Canons appear, mostly at the unison, but often with short temporal distances, e.g., two beats or less; and in multiple voices at once, e.g., a canon of an entire block of sound. Formal construction is frequently episodic, with blocks sometimes following abruptly but more often softened or prepared with brief transitional passages. These are canons that for the most part generate clusters of shifting but static harmonies and are thus unlike canons from the common practice period. At the same time, they are not as dense or ambient as, for example, the micropolyphony of György Ligeti. ${ }^{52}$

Additive and collage-like procedures of the post-minimalist variety are quite common, used more with an interest in dramatic effect than the procedure itself. ${ }^{53}$ Jonathan Bernard describes musical developments after the arrival of minimalism as proceeding through four stages, the fourth of which is "harmony of an ever more tonal (or neotonal, or quasi-tonal) aspect" and with other traditional elements of minimalism far less significant (e.g., "repetition in

\footnotetext{
${ }^{52}$ For example, Atmosphères (1961).

${ }^{53}$ Interest in drama also distinguishes this music from traditional minimalist or process music. Talbot does not permit a particular process to continue beyond the dramatic needs of the moment.
} 
a buzzing or bustling texture, explicitly projected pulse, the pantonal sonorous profile")..$^{54}$ This clearly is where Talbot sits: squarely in postminimalism. Early minimalists rejected personal expression and sought to establish a process which permitted music to unfold according to prearranged terms. As Steve Reich explained, "I am interested in perceptible processes; I want to be able to hear the process happening throughout the sounding music." And then, "once the process is set up and loaded it runs by itself." ${ }^{55}$ Talbot, by contrast, is not interested in removing the composer from the scene of composition. Instead he places himself in the music, working with each musical element at his disposal to portray and evoke the particular drama of that moment. POM applies some established minimalist compositional techniques (such as continuous propulsive rhythms, diatonic and modal harmonies, reference to variety of different genres, etc.) in ways that serve an esthetic aim that is quite different from what the early minimalists had in mind. $^{56}$

Multiple layers of different blocks of sound, as well as additive melodic, harmonic and rhythmic constructions, appear frequently. The interplay between and within these constructions adds meaning. Often, the process is more complex than simple addition, if viewed as taking an idea and adding on to the end. Sometimes additions are in the middle, or sometimes different blocks are added or combined in other ways, yielding something more like a collage effect. ${ }^{57}$

\footnotetext{
${ }^{54}$ Jonathan W. Bernard, "Minimalism, Postminimalism, and the Resurgence of Tonality in Recent American Music," American Music 21, no. 1 (2003): 114, doi.org/10.2307/3250558. ${ }^{55}$ Quoted in Bernard, "Minimalist Aesthetic," 1993, 107.

${ }^{56}$ For a detailed exploration of postminimalist techniques in POM, see Meade, "Pilgrimage and Postminimalism in POM," 66-68.

${ }^{57}$ This is not to suggest that Talbot is breaking new ground here. Indeed, Steve Reich in the 1970s (e.g., Music for 18 Musicians) inserted material in the middle of a minimalist melodic construction. It is, in fact, difficult to find in POM novel compositional techniques, except, perhaps, for the incorporation of ethnic Bunun music at the opening. Instead, Talbot's
} 
Also striking is how much of POM relies on purely stepwise motion, often evocative of a pilgrim's gait. Even the widest leaps rarely span more than a fifth, and when they do occur, they often serve a significant dramatic purpose.

The bare text offers little in the way of specifics about the undertaking and assumes from the audience a basic understanding of the nature of pilgrimage. POM relies on the music itself to provide much of the psychological, emotional and even dramatic content. The music not only adds complexity, nuance and clarity, it creates drama which is sometimes different in important ways from the text itself. Included in this document is an identification of the actual emotional or dramatic or psychological character that is present. Of course, the music relies on the text in important ways as well. While a particular musical utterance may be subject to a number of varying interpretations, once it is yoked to a text (and, here, reasonable inferences about the pilgrimage experience), the music's contribution to the dramatic content can itself be revealed with greater clarity.

Talbot's ability to express feelings of aloneness, even in a multi-voice medium, is remarkable. However, despite touching moments of individual contemplation and loneliness, POM is fundamentally a piece about communal rather than individual spirituality. One of the elements of pilgrimage, particularly the now-popular Camino de Santiago, is that others join on the path, offering opportunities for developing community on the road.

contribution is combining established techniques in new ways which create a remarkable dramatic and musical impact. 


\section{CHAPTER 2: "RONCESVALLES"}

\section{A. Pasiputput Opening}

One of the most striking aspects of the piece is its extended $2 \frac{1 / 2}{2}$ minute opening. Starting from nothing, with the stage empty and black, a rumbling utterance arises from the depths that, after the sound has reached [ppp], continues a long crescendo, with basses and tenors at the bottom of their range. After 3 bars, they start slow ascending glissandi; when a singer stops to breathe, he re-enters below the sung pitch and glissandos back up. The technique is mysterious, strange and quite striking. The music is adapted from the Pasiputput music of the aboriginal Bunun people in Taiwan, music which has fascinated Talbot since his teenage years listening to BBC Radio. ${ }^{58}$ Talbot remembers that this music immediately drew him in, generated alarming intensity and caused hallucinations. ${ }^{59}$ Starting the piece with such newness (to western ears) and such quiet that then blossoms ${ }^{60}$ into sheer excitement evokes in a unique way the manner one imagines a pilgrimage might begin.

A pilgrimage does not begin in the same way for each individual. Each person brings their own background and experiences and their own reasons for the undertaking. Reasonably enough, many pilgrimages start first as something quite vague, maybe even less definite than a feeling — rather more like a general uneasiness - that, over time, develops into something that carries such force that the individual commits to the formidable physical and spiritual dedication pilgrimage requires. Talbot effectively captures this model of preparation for a pilgrimage,

\footnotetext{
${ }^{58}$ Leibrock, "Path of Miracles Program Booklet, Conspirare," 4. Perhaps Talbot is channeling Wagner here as well, whose Der Ring des Nibelungen starts from nothingness and arises slowly from the depths before introducing a harmonic foundation.

${ }^{59}$ Leibrock, 4.

60 Talbot notes that Pasiputput ritualizes the annual planting whose success is determined by the purity of the sung intervals and the power of the overtones produced and compares his compositional process to agricultural work. "From the Composer," in Leibrock, 4.
} 
beginning with individual questioning and with a gradual transition from uneasy feeling to more and more definite goal. He focuses on the generalized emotional content and the transition from feeling to commitment, a musical expression that is accomplished without regard to the particular goals or rationale of any particular pilgrim.

This is one of the hallmarks of POM. It presents generalized pilgrims filled with enough specific factual elements that the listener can recognize, keeping focus firmly on the power of the emotion that affects and drives them. The generalized nature of the factual situation enables the listener to identify with the underlying emotion despite the absence of individualized character development of opera or other traditional theatrical forms.

Talbot's writing, here and throughout POM, coincides remarkably with social science research on the nature of pilgrimage. Meade describes three stages of pilgrimage as set forth in the anthropology literature ${ }^{61}$ In the first stage, "origination," pilgrims assess their goals and withdraw from the mundanities of daily life. Pilgrims may identify their personal pilgrimage as an opportunity for penance, or to serve punishment, or explicitly to seek miracles in the hope of a cure.$^{62}$ Some identify pilgrimage as itself an act of prayer or meditation, or hope for an awakening of transcendence in their lives.$^{63}$ The second stage, referred to as the "liminal state," strips the life of the pilgrim to its essence: common purpose connects pilgrims to each other, developing profound bonds of "communitas." The "ordeal" of pilgrimage contributes to the

\footnotetext{
${ }^{61}$ Meade, "Pilgrimage and Postminimalism in POM," 17-20; relying on Victor Turner and Edith Turner, Image and Pilgrimage in Christian Culture (New York: Columbia University Press, 1978), 6, 9-11, 25, 27, 34.

62 James is recorded to have performed dozens of miracles, including restoring the dead to life. Interestingly enough, however, he performed no medical cures, and thus pilgrims seeking cures more often follow other pilgrimage routes, such as to Lourdes in France.

${ }^{63}$ Coffey and Dunn, Miracles and Translatio, XVII.
} 
vulnerability of the pilgrim, making them open and susceptible to religious imagery, reflection, purification, transformation, transcendence. ${ }^{64}$ The final stage of "arrival" presents the potential of transformation as a miraculous reward for the undertaking. ${ }^{65}$ The form of this stage varies from one pilgrim to the next, but can be a profoundly spiritual and transformative experience.

\section{B. The Pilgrims' Hymn and the Miracle Cell}

Out of the mists of the initial Pasiputput-inspired opening in the lower voices comes a piercing E minor second inversion chord in the upper voices, singing a traditional text from a liturgical chant found in the Codex Calixtinus, Dum pater familias. ${ }^{66}$ Dum pater familias is a hymn of praise to St. James and its final lines, known as the Pilgrims' Hymn, serve as a greeting between pilgrims to this day:

$\begin{array}{ll}\text { Herr Santiagu } & \text { Holy Saint James } \\ \text { Grot Santiagu } & \text { Great Saint James } \\ \text { Eultreya esuseya } & \text { God help us now } \\ \text { Deius aia nos } & \text { And evermore }\end{array}$

The hymn appears at key points throughout POM. Here, at the onset of the journey, the Pilgrims' Hymn constitutes pilgrims' first corporeal utterance, and must evoke both the prayer itself as well as their thoughts and emotions as they begin their journey, arriving, as they do, from

\footnotetext{
${ }^{64}$ Meade, "Pilgrimage and Postminimalism in POM," 18-19.

${ }^{65}$ Meade, 19.

${ }^{66}$ Much of POM borrows from ancient musical styles in ways which evoke both the timelessness of a pilgrim's journey and a connection to the many pilgrims who have traveled the route in prior centuries. Goolsby and Meade both discuss this borrowing. However, Talbot's music for this text bears no resemblance to the musical setting in the Codex Calixtinus. See Daniel Savarese, "Dum Pater Familias (The Song of Compostela) (Anonymous) - Savarese.Org," accessed March 12, 2020, savarese.org/music/DumPaterFamilias.html. This is also the case for the other musical settings from the Codex that I have been able to locate (temporary emergency library closure has prevented access to some items which might more definitively answer this question). Talbot seems to have in mind a particular musical conception of the piece, and by incorporating ancient styles in ways which do not impact his harmonic or pitch conceptions, he is perhaps more easily able to implement his own ideas in these areas.
} 
different parts of the earth and with different expectations, but all hoping for a meaningful experience. The striking E minor is both fearful but also elemental and exciting. Together with the text it conveys a somewhat forced, even brittle effort to praise St. James here at the outset of the journey, when perhaps pilgrims in fact know little about him.

Talbot's setting carries within it a motivic seed, referred to here as the "miracle cell," both for its transformative possibilities and for its use in generating a feeling of spiritual transformation as the drama of POM reaches its conclusion. The miracle cell predominates in the first movement and serves as a focal point for the movement's pointed half-step dissonances. Its basic form consists of pitches A B C, ordered B A C. The miracle cell is reshaped and transposed throughout the piece, but in its elemental and unordered form it contains the intervals of a whole step (A-B), a half-step (B-C) and a m3 (A-C). The cell makes occasional appearances at critical points in subsequent movements. As a result of its simplicity, it is capable of transformation into a variety of different emotional and musical contexts, but because it remains audible musically, it also serves to unify the music and carry along the pilgrims as they make their way. Moreover, the miracle cell grows longer and longer by adding pitches, providing continuity and direction; it is also expanded in its pitch content through transposition.

Like the Pasiputput opening which arises from nothingness, the cell is introduced with but the barest of musical materials. Although it may be that a genuine motive really cannot take shape with fewer than three pitches, a composer may surely foreshadow an important musical idea. That is what Talbot does here, prominently introducing the first pitch during the initial Pasiputput opening. Basses in m. 6 arrive at B3, which they sustain and crescendo, while the tenors ascend another octave. Meanwhile the sopranos and altos, with their Em stentorian entrance at 8 also emphasize the pitch B, so that the ensemble includes 13 voices singing $\mathrm{B}$, but 
only two on $\mathrm{G}$ and two on $\mathrm{E} .{ }^{67} \mathrm{~B}$ is both the highest and lowest sonority. Then, in $\mathrm{m} .13$, Talbot introduces the second pitch of the motive and the first pitch outside the E minor triad, $\mathrm{C}$, and effectively emphasizes the half-step dissonance between $\mathrm{B}$ and $\mathrm{C}$, the $5^{\text {th }}$ and $6^{\text {th }}$ scale degrees of the Em tonality. ${ }^{68}$ Half-step motion, in a variety of relations to the tonal center, plays a significant role in POM.

The miracle cell makes its first complete appearance in $\mathrm{m} .18$, as a cadential figure in the S1 voice, echoed canonically in T1-2 (Fig. 2). The underlying harmony changes so that the motion from $\mathrm{B}$ to $\mathrm{C}$ (now through $\mathrm{A}$ ) serves as a resolving figure to the new Am sonority. ${ }^{69}$

${ }^{67}$ The entrance harkens back to the opening of Stravinsky's Symphony of Psalms, also in E minor, which generates harmonic interest by the way a sonority is voiced, there emphasizing the G.

${ }^{68}$ References to "tonality" describe the most prominent pitch of a particular section, as POM rarely uses functional harmony of the common practice period variety.

${ }^{69}$ In this formulation, the motive also harkens back to an ancient style in which phrases sometimes ended with an "under third," sometimes called a "Landini" cadence popular in the $14^{\text {th }}$ century. 
Figure 2. I/17-24. ${ }^{70}$

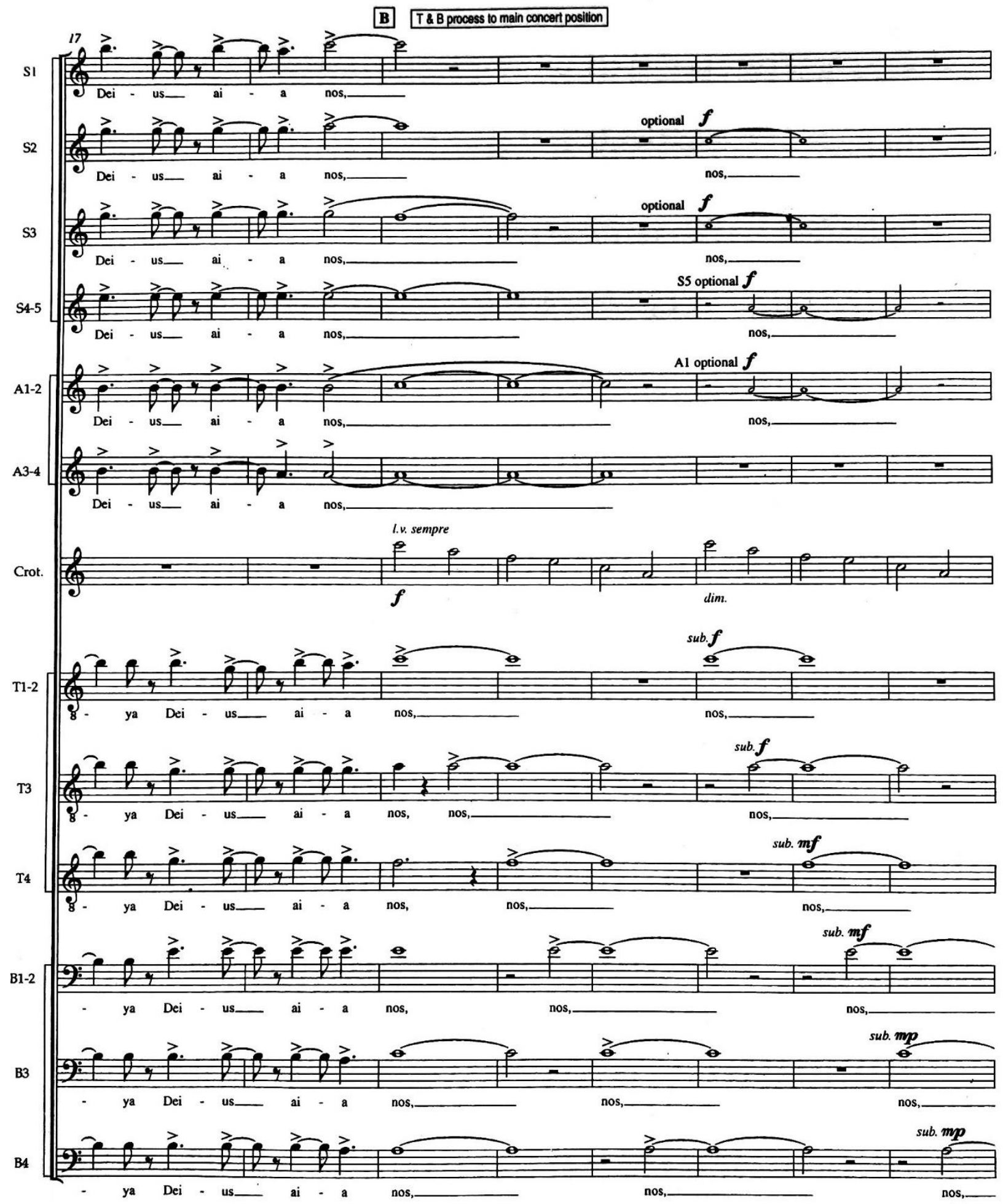

${ }^{70}$ Musical excerpts are from Talbot, Path of Miracles, text by Robert Dickinson, Copyright (c) 2005 Chester Music Limited, International Copyright Secured, All Rights Reserved. Excerpts are reprinted by permission of Hal Leonard LLC. 
One potential mode of analysis for these kinds of intervallic relationships is the approach developed by Allen Forte, under which this cell is a realization of pitch class set 3-2 [ [ $\left.\begin{array}{lll}0 & 1 & 3\end{array}\right]$. Forte terminology is useful here because the pattern of whole and half-steps in POM is sometimes altered (e.g., $\mathrm{A} \mathrm{B} b \mathrm{C}$ ) and this terminology recognizes this as the same set class. But given the additive nature of Talbot's work, Forte set class designation only partially captures what is happening. For example, Talbot sometimes expands the cell by a m3, sometimes by a M3, and sometimes both in either direction. In POM, each of these expansions includes the miracle cell and is directly related to it. A pitch class analysis, however, would identify these as different, albeit related, sets. All of these expansions are related to the original cell in registrally fixed ways and preserving much of the pitch content, and this relationship must be made clear. In addition, the expansions that Talbot chooses are often related to the underlying tonal harmony, so that, for example, the pitches A B C expanded by a M3 yield different harmonic tertian and neotonal possibilities than when expanded by a m3.

Talbot's use of additive harmonic procedures is readily apparent at the outset here as well. The harmonic underlay at $\mathrm{I} / 8^{71}$ includes only the pitches E G B C (except for the Pasiputput glissandi). At m. 18, A is added to the wash of sound, and then at 19, F. Dramatic tension is heightened by the increasing number of pitches. Frequently, this also serves to thicken the texture. In combination with other elements moving in the same direction, this can enhance dramatic expression.

\footnotetext{
${ }^{71}$ Where not otherwise clear, the movement in Roman numerals precedes the measure number.
} 


\section{The Pilgrims' Introduction to St. James}

\section{The Martyrdom of St. James}

"Roncesvalles" continues with an extended recitation, in multiple languages, of the biblical description of James's martyrdom.

Now about that time Herod the king stretched forth his hand to vex certain of the church. And he killed James, the brother of John with the sword. ${ }^{72}$

The pitches of the miracle cell appear quite dramatically with the first recitation in the A3 solo at mm. 26, in Greek (Fig. 3). ${ }^{73}$ The B serves as a harsh and repeated dissonance against the descending Am harmony which began in m. $19,{ }^{74}$ but then cadences in motion from A to C. This solo contains only these three pitches with rhythm evocative of ecclesiastical chant, and over the same harmonic underlay. The dissonance starkly hits pilgrims (and listeners) with the cold fact that James was horrifically martyred. Repeated utterance of this motive drives the point home, each B $\sharp$ evocative of Herod's slashing sword. ${ }^{75}$

\footnotetext{
72 Acts 12:1-2; biblical translations are from the King James Version.

${ }^{73}$ Alto 3 is denoted A3; Tenor 2 as T2, and so on.

${ }^{74}$ It is tempting to hear this as an FM7 sonority. However, the A appears consistently in the bass, and the mild dissonance between 5 and 6 (here in A minor between $\mathrm{E}$ and F) appears frequently in the harmonic language of POM. Note also that Edward T. Cone has observed that a subsequent passage may allow the ear to reinterpret, or even clarify, what was heard previously, but that nonetheless, on first hearing, mystery - in this case between Amb6 and FM7 - is what is experienced by the listener. Edward T. Cone, "Three Ways of Reading a Detective Story, or a Brahms Intermezzo," The Georgia Review 31, no. 3 (1977): 554-74.

75 This is reminiscent of the oboes in the opening chorus of Bach's St. John Passion, where a chain of suspensions has been interpreted as the piercing nails of the crucifixion. Manfred Honeck, during Pittsburgh Symphony rehearsal, March, 2016.
} 
Figure 3. I/26-29, A3 (solo).

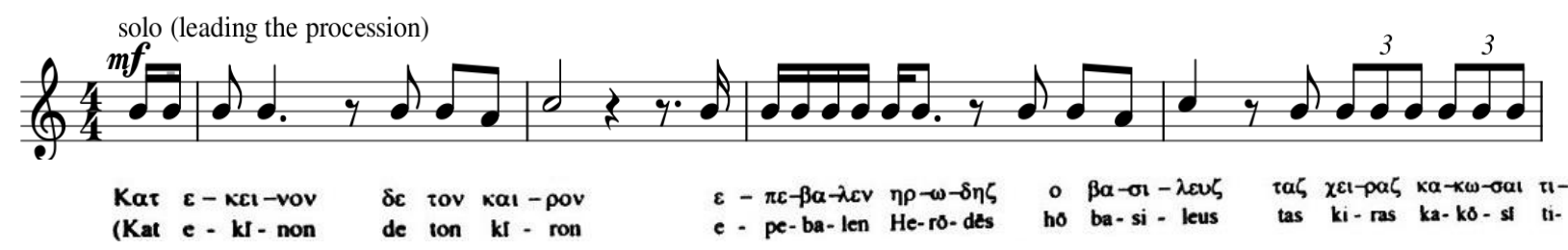

The same biblical passage is repeated in six other languages. Each in its own way (and

with its own music), express the horror of the slaying and expresses, in slightly different musical terms (many of which contain the miracle cell), a pilgrim's reaction to this stark fact. Use of different languages and musical materials evokes the multiple origination points of pilgrims, still speaking their own language, somewhat separate from one another having not yet formed the bonds of "communitas" that are part of the connected pilgrim experience.

The Latin version of the text, beginning at $\mathrm{m}$. 55, contains a jaunty modal melody which contains both a raised and lowered third scale degree, sometimes known as Spanish Phrygian mode (Fig. 4) ${ }^{76}$ The melody focuses on the E triad, but also contains motion from B to C, passing through A. The melody contains a significant tail, starting at 59. This tail contains the miracle cell transposed and inverted to E F G (i.e., still 013 in a Forte analysis). The tail becomes significant by itself later in the movement (e.g., m. 123 S3-4; m. 194 S4; m. 424 S1-5, transposed; m. $505 \mathrm{~S} 3, \mathrm{~S} 5, \mathrm{~T} 1$, transposed). It plays a role in the final movement as well. The tail motion emphasizes the Phrygian nature of the melody, with the F an almost continual passing tone over the E-based harmony.

\footnotetext{
${ }^{76}$ See, e.g., Tom Hojnacki, Introducing the Spanish Phrygian Scale, Berklee Online, accessed March 25, 2020, youtube.com/watch?v=yRggh1XXZZI. The mode is sometimes used in modal jazz idioms where it can accommodate major triads on each of the first three scale degrees. One example is "La Fiesta," by Chick Corea. Chick Corea, Chick Corea - La Fiesta, accessed March 25, 2020, youtube.com/watch? $\mathrm{v}=8 \mathrm{eVuwsimbtw}$.
} 
Figure 4. I/55-62, A1-2.

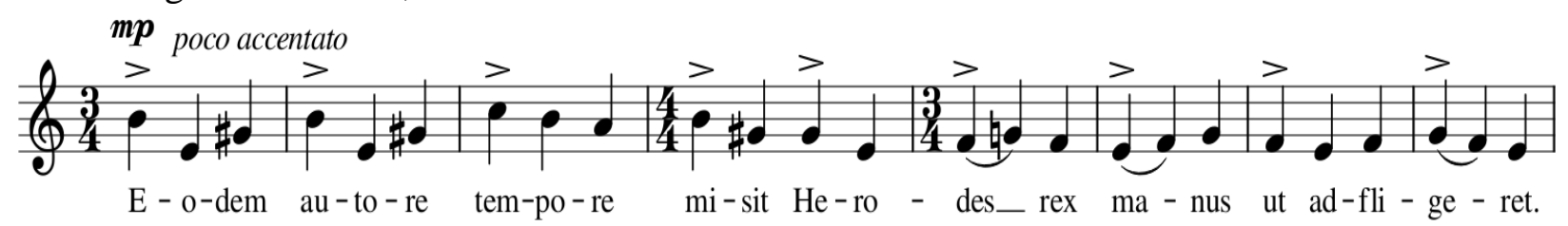

The biblical passage in Medieval French begins at $\mathrm{m} .131$ and is generated through an additive process beginning with just four pitches (B D A B), but then in its full form, with additional material added both before and after the cell that was initially presented, finishes with the miracle cell similar to the tail of the Latin theme, on the pitches D E F (m. 143): specifically, E D F E. This tail becomes a prominent motive in the next section (through 209), again emphasizing the Phrygian harmony by circling the tonic (Fig. 5).

Figure 5. I/131-144, S5 (solo).

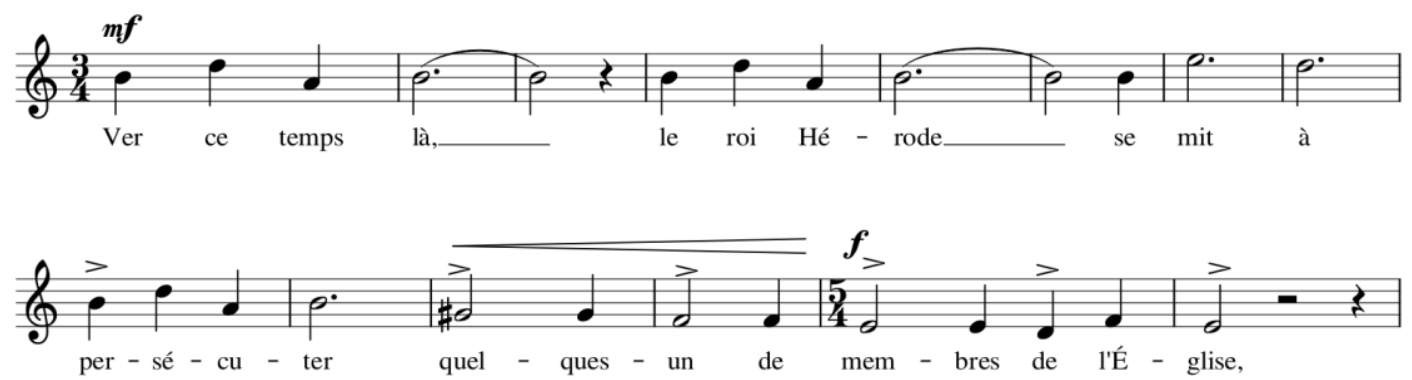

Meanwhile, a new motive in French, also constructed by additive means, begins in A1/3. The main miracle cell is present (transposed to D E F), but it adds a minor third below (B) as well as a minor third above $(\mathrm{G \# )}$ and then an additional half step above (A). Altogether, this melody contains two iterations of the miracle cell, D E F and G\# A B - Talbot makes use of this connection in $\mathrm{m} .153$, where more material is added to the end of the motive (Fig. 6). This new motive also appears later in the piece (sometimes without the added A above). The procedure 
maintains a familiarity with the preceding material but also generates a new theme which permits us to hear it in a different, but still dramatic way.

Figure 6. I/153-157, A1/3.

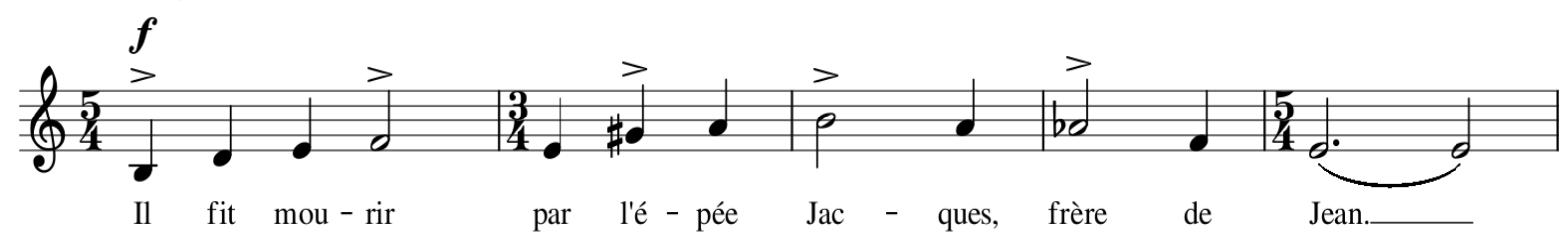

In m. 210, the English theme begins with the miracle cell in a transposition $(\mathrm{Bb} B$ 古 $\mathrm{C} \#)$, also with an inserted $\mathrm{m} 3$ below (G) (Fig. 7). The second phrase begins with the same motive, but prefaced with miracle cell pitches B C\# D. In m. 226, the motive introduces the German text (E F G) and then in m. 242 continues with the motive transposed to $\mathrm{B} b \mathrm{~B} \sharp \mathrm{D} b$, as in the English theme (Fig. 8).

Figure 7. I/210-220, A4.

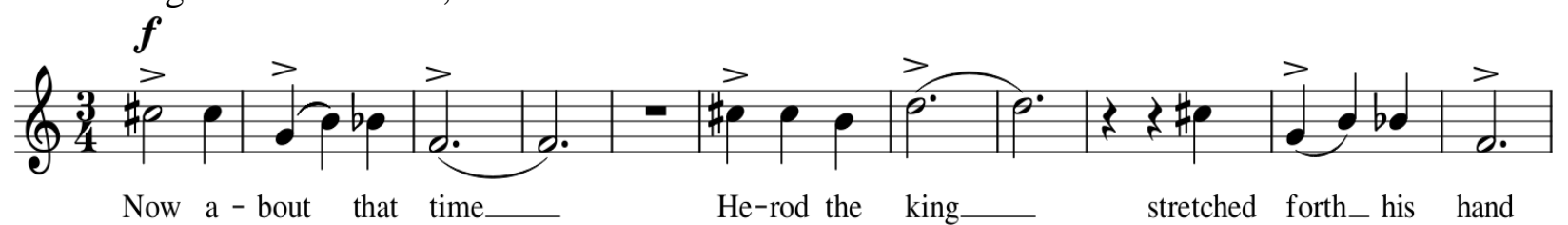

Figure 8. I/226-235, B1-2.

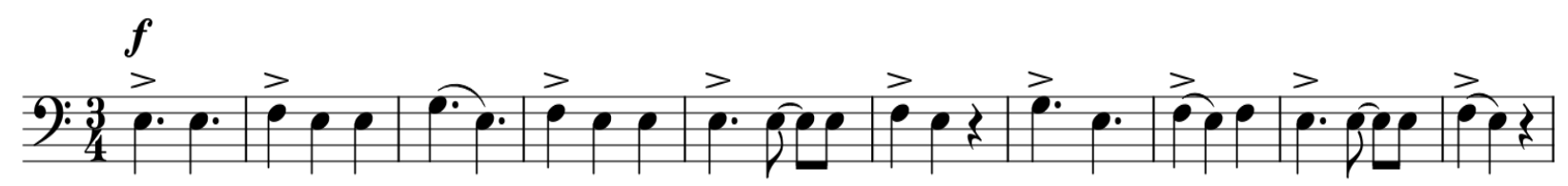

Um die - sel-bi-ge Zeit leg-te der Kö-nig He - ro-des die Hän - de an, et-li-che von_

After this, one of the dramatic potentialities of the miracle cell becomes apparent. In $\mathrm{m}$. 248, the German theme (B1/2) begins to expand, taking the $\mathrm{m} 3$ (Bb-Db), expanding it to $\mathrm{M} 3$ (Bb- 
$\mathrm{D} \sharp)$ then tritone $(\mathrm{B} b-\mathrm{E})$. This alteration creates excitement which is matched a few bars later in expansions generated by the other voices. In mm. 256-57, the outer voices expand outward, increasing the harmonic intensity and variety (Fig. 9). They also expand the overall vocal range from top to bottom so that the return of the Pilgrims' Hymn at m. 258 arrives with significant dramatic impact and in the surprising key of Eb (Fig. 10). This is no longer a group of pilgrims who express a kind of surface-level appreciation for James, as perhaps they naively did in their full-throated appeal back in m. 8; it is instead a cry of agony as they express the hymn with full, seven-language knowledge: they know what befell this holy man and have a more fully informed understanding and appreciation of how he suffered for his beliefs. They also, perhaps, carry a deepened knowledge of the symbolic suffering and penance that pilgrims will endure in the course of their journey. They sing the miracle cell transposed to A Bb $\mathrm{C}$ and appearing in those hymn-singing voices (except those with straight repeated pitches) through m. 311.

Figure 9. I/251-257, piano reduction.

Text: S, A, T: "the brother of John with the sword"

B1-2: "Jakobus, den Bruder des Johannes, mit dem Schwert."

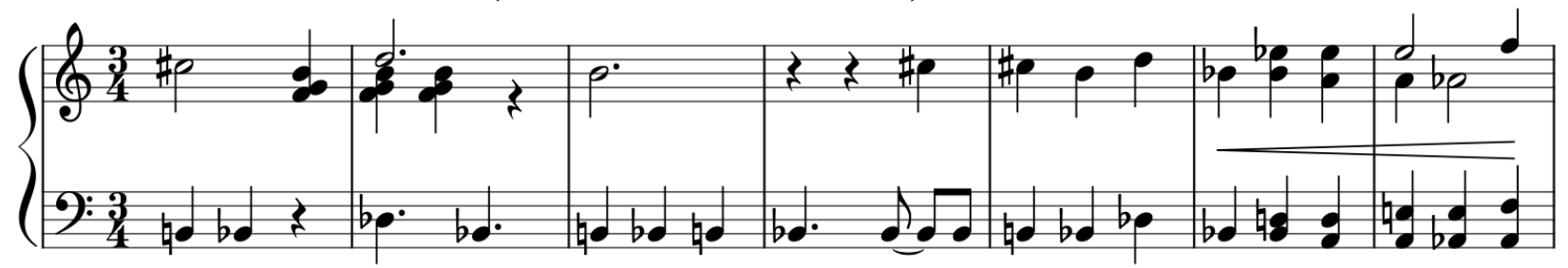


Figure 10. I/258-265.

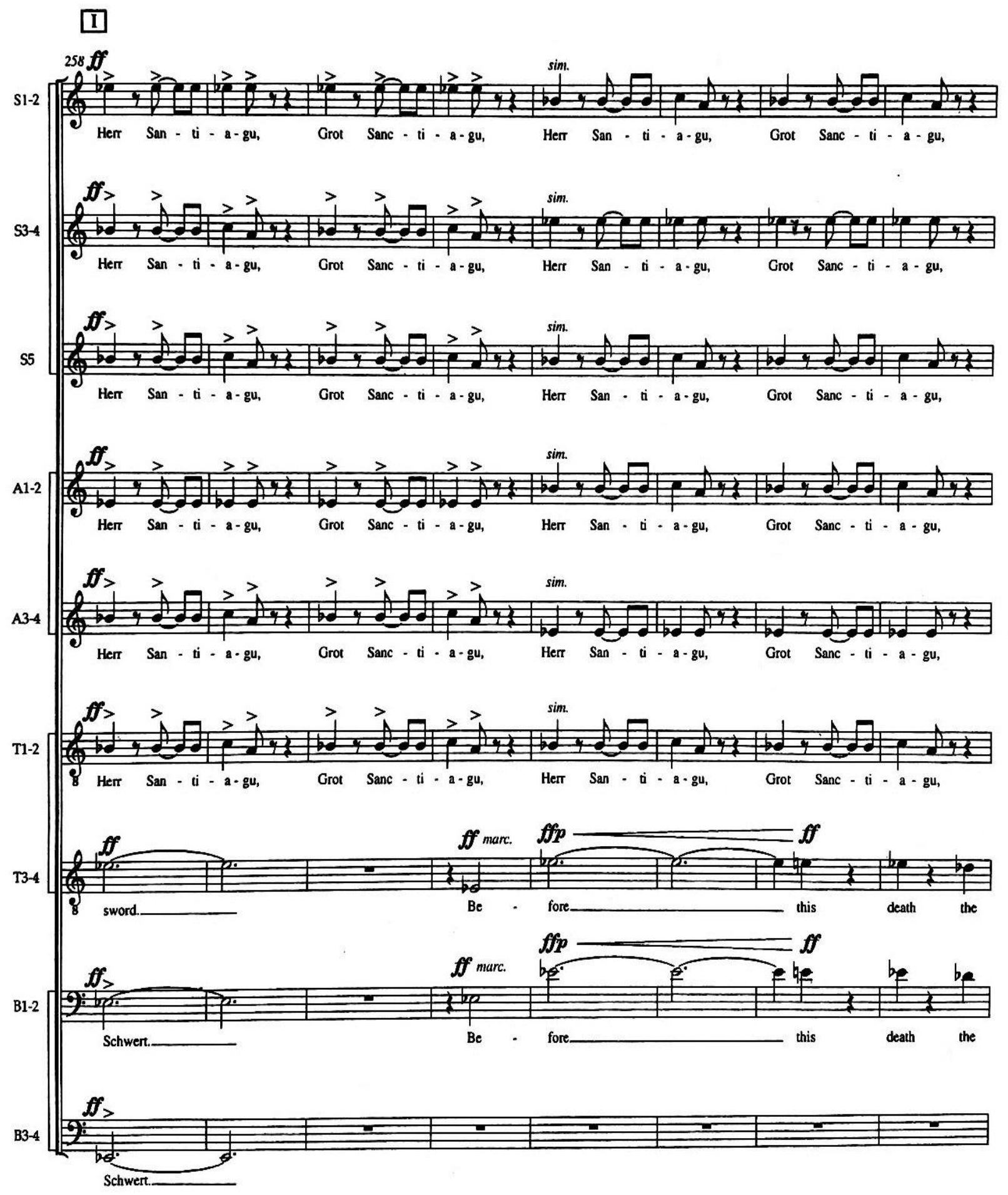




\section{James Spreads the Gospel}

With the pilgrims' enhanced knowledge as background and beneath the forceful praise for St. James that continues in the upper voices, T3-4 and B1-2 (m. 261) erupt to announce the first of James's great achievements, preaching and spreading the word of Christ (see Fig. 10). This relationship makes plain the difference between a theoretical or surface understanding of an event and a deeper, more personal connection or engagement. It is as though the pilgrims, just starting their journey at m. 5, could articulate a praise for St. James, but its depth and power and meaning were limited by their still-fresh memories of the non-religious world. Now, having learned more deeply through repeated incantation of the passion of St. James, their understanding and their emotional engagement are deeper and more profound. The miracle cell announces this achievement, $\mathrm{Db} \mathrm{Eb} \mathrm{E}$. Again, additive processes in melodic generation are present, as the theme starts with just these pitches for its first iterations, though lengthening the treatment. In 282, Talbot transposes the motive, but keeps the $\mathrm{Eb}$ and $\mathrm{Db}$, adding $\mathrm{C}$ to complete the set (Fig. 11). Again in 284, he transposes to $\mathrm{Bb} \mathrm{C} \mathrm{Db}$. In 285-86, he keeps $\mathrm{Bb}$ and $\mathrm{C}$, adding A to complete the transposition. These rapid-fire transpositions of motives generate excitement at the same time that the work remains tethered to the path. These changes make apparent one of the striking features of the miracle cell: a string of them will generate the octatonic scale, and POM includes a nearly complete octatonic scale in this section.

Figure 11. I/280-87, T3-4; B1-2.

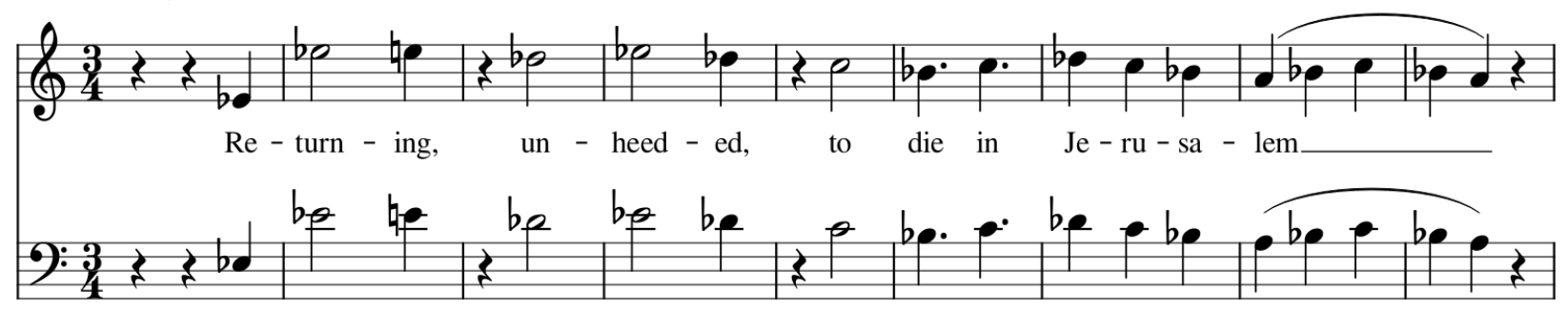

$$
\text { Re - turn - ing, un - heed - ed, to die in Je - ru - sa - lem }
$$




\section{Translatio of St. James}

At this point, the texts begin to describe the translatio $^{77}$ of James's remains from

Jerusalem to Galicia, and then the re-discovery of his hidden tomb in the $9^{\text {th }}$ century. At m. 336, set to driving minimalist rhythms, is the description from Florus of Lyon, in his Martyrologium, as revised by Ado of Vienne, of the translatio. ${ }^{78}$ At $\mathrm{m} .368$, the means of transport is made more definite if not more believable:

From Jerusalem to Finisterre, from the heart of the world to the end of the land in a boat made of stone, without rudder or sail.

This text draws upon a legend not set forth in the Codex Calixtinus and in fact discounted by it. According to the translatio set forth in Book III, several Galicians whom James had converted traveled with him to Jerusalem. After he was martyred they carried his body back, sailing across the Mediterranean on a boat that appeared for them in Joppa. Upon arrival, they found a pagan structure, destroyed the idol there and rebuilt it into a tomb for the apostle. Two Galicians remained by the tomb as caretakers and were later buried there. Three separate descriptions, each focusing on different details of the events, are set forth in Book III. ${ }^{79}$ None of these, however, describe a "boat made of stone."

77 This Latin term, ordinarily meaning "translation," carries a specific ecclesiastical definition: "the transfer of a saint's remains (body or part thereof) from its initial resting place to another, as well as to the narrations that describe these transfers." Coffey and Dunn, Miracles and Translatio, LIX.

${ }^{78}$ Melczer, The Pilgrim's Guide to Santiago de Compostela, 12-13. The additional Latin text is from the $15^{\text {th }}$ century Miragres de Santiago. It is perhaps noteworthy from a factual perspective that the Codex Calixtinus, though compiled long after the re-discovery, contains no mention of it. Coffey and Dunn, Miracles and Translatio, XXXVI.

${ }^{79}$ Coffey and Dunn, Miracles and Translatio, LXIV. 
Elsewhere, in a sermon for the Feast of the Translation (known as Veneranda Dies), the Codex Calixtinus summarizes the account of the transfer of the body but also refutes several false reports about it, including the notion that the body was carried across the sea on a large stone:

Things that many irrational people, torpidly sliding toward heresy, are accustomed to say about James and his translatio should be announced so as to be corrected. What is worse, people dare to write about these things with a false pen. Some, for example, ... say that he came from Jerusalem to Galicia over the waves of the sea without a boat, sitting on a large stone with the Lord instructing him, and that a certain part of this large stone has remained behind in Joppa. Others say that this very stone arrived on the boat together with his lifeless body.

However, I declare both stories to be false. Truly when I once saw the great stone, I knew it was a stone created in Galicia. ${ }^{80}$

It is just this stone boat legend (as adapted by Dickinson) which is set forth in POM, to the Spanish Phrygian theme. Selection of this version makes clear some of the artistic choices made in this musical depiction of pilgrimage. Although pilgrims travel for many reasons, one is the hope for a transcendent experience ${ }^{81}$ and Talbot certainly aims to capture something of this in POM. However, by citing a particularly fanciful legend that is not included in the Codex Calixtinus and is in fact repudiated by it, the text separates pilgrims from reality. ${ }^{82} \mathrm{We}$ are, of course, in the world of religion where the power of faith including the medieval concepts of

\footnotetext{
${ }^{80}$ Coffey and Dunn, 134.

${ }^{81}$ Meade, "Pilgrimage and Postminimalism in POM," 18.

${ }^{82}$ This text is a paraphrase by Dickinson of the legend. Coffey and Dunn explore each of the ancient sources related to St. James and find no written record of the stone boat legend up until compilation of the Codex Calixtinus. Nonetheless, "the refutation of some versions of the Translatio suggests that these other stories were in circulation and common enough to warrant attention." Coffey and Dunn, Miracles and Translatio, LXI.
} 
miracles are part of a pilgrim's hoped-for transcendence. Nonetheless, their eager reciting of the tale now carries a cast of desperation as pilgrims reveal themselves as not just seeking purity, penance, redemption and openness to a deep and abiding faith. Instead they are portrayed as emotionally weak, perhaps desperate even, grasping at anything that hints of the otherworldly. It is as though the pilgrims have no powers of objective observation or individual self-awareness and are trapped in a desert of emotional anguish. Perhaps Talbot (and Dickinson) merely seek to present the most mystical and evocative images that are part of the lore of the Camino. This story is certainly quite evocative. But in the process, they at a minimum run the risk of portraying pilgrims as "irrational people, torpidly sliding toward heresy." 83

\section{Rediscovery of the Tomb}

To complete the important events related to James's life, the end of the movement recounts the rediscovery of James's tomb in Galicia. This rediscovery, which took place in the early $9^{\text {th }}$ century, is first described in writing in a land agreement from 1077, which states that the tomb was revealed by angels to the hermit Pelayo during the reign of Alfonso II ("the Chaste") (r. 783 and 791-842), and prior to the death of Bishop Teodomiro (d. 847). ${ }^{84}$ Townspeople saw "heavenly lights" directed toward the spot of the tomb, covered by a marble stone. After three days of fasting, the bishop found the sepulcher. ${ }^{85}$ The music is set to the Spanish Phrygian theme transposed to Bb. The Pilgrims' Hymn returns, piano, as pilgrims express praise for St. James in

${ }^{83}$ Coffey and Dunn, 134. The possibility that Talbot and Dickinson were unaware that the stone boat legend had been rejected should also be addressed, although this seems unlikely. Talbot and Dickinson relied heavily on the Codex Calixtinus as a source for texts in POM. In addition, they consulted a Spanish history scholar in preparation of the work and selecting the ancient texts. Crouch, POM CD Liner Notes, 5. The "Veneranda Dies" sermon has been available in English translation since 1996. Coffey and Dunn, Miracles and Translatio, XLIII.

${ }^{84}$ Coffey and Dunn, Miracles and Translatio, XXXVI.

${ }^{85}$ Coffey and Dunn, 122. 
a reflective and subdued manner. The hymn is interspersed with a reminder of the Pasiputput mysteries as pilgrims recall their goals and objectives for the journey. As the movement draws to a close on a Bb open fifth, the mood can best be described as one of shock, as pilgrims attempt to make sense both of what they have learned about St. James and perhaps what pilgrimage itself will mean for them. 


\section{CHAPTER 3: "BURGOS"}

\section{$\underline{\text { A. POM's use of Musical Blocks }}$}

"Burgos" is where pilgrims suffer. The tedium and effort of continually trodding along a path, combating a variety of dangers and temptations, tests them. Together with the suffering comes the opportunity for meditation and possibly transformation.

The first movement contains the Pilgrims’ Hymn of praise, biblical passages, a recounting of James's "translatio" from Jerusalem to Spain and the subsequent re-discovery of his tomb in the $9^{\text {th }}$ century. These are all events external to the pilgrims as they begin their journey and learn about important events related to St. James. The end of the movement finds pilgrims in a reflective state, contemplating both what they have learned and what they have committed themselves to over the next weeks. "Burgos" finds pilgrims more aware of their own reactions to the pilgrimage and the events and teachings along the way. The movement introduces the Pilgrims' Voice, a sort of narrator function, sometimes filled by a single voice, sometimes by a group, sometimes passed from one voice to the next. The Pilgrims' Voice describes, in English, ${ }^{86}$ the collective experiences faced by pilgrims - hardships of the road, towns and villages along the path, reflections on their journey.

"Burgos" evokes the liminal stage of pilgrimage and develops the emotions of this stage musically through a complex and interactive compositional process, more of a collage than simple addition. Different melodic, harmonic and rhythmic blocks are introduced, sometimes

${ }^{86}$ Talbot now adopts English as a lingua franca to describe the pilgrims' experience. United in the first movement by a common understanding of Saint James, they have started to develop bonds with each other. POM's assumption of a common tongue to describe their experiences helps to express this new-found camaraderie, the beginnings of "communitas." 
pasted together, sometimes presented alone, but always sensitive to the requirements of telling the story and evoking the drama of the experience.

Before delving into the ways that these blocks interact and evoke the liminal state of pilgrimage, however, it is worthwhile to note the transition from "Roncesvalles" to "Burgos," which illustrates both the importance of half-step motion in POM generally as well as Talbot's use of this motion here in a manner that serves to generate continuity and also to evoke pilgrims' changing psychology. Musically, POM shifts by a half step, moving from the Bb open fifth of the conclusion to the A minor opening of "Burgos." But the opening sonority contains within it a remnant of the prior movement: the $\mathrm{B} b$ remains as a dissonant $\mathrm{b} 9$ against $\mathrm{A}$ minor. In this way, POM is able to shift from the mood of one movement (and pilgrimage stage) to another while at the same time maintaining a continuum as pilgrims continue their journey.

The movement is divided into multiple musical blocks, each portraying different elements of the story seriatim and sometimes in combination as the movement unfolds (Fig. 12). ${ }^{87}$ Each of these blocks interacts with the others and relates to pilgrims' emotional and physical state at this point in the pilgrimage. Block 1 incorporates the music at $\mathrm{m} .1$, a set of parallel triads combined with a striking Bb dissonance (with a dipping $\mathrm{m} 3$ and evocative tail) that evokes an aimless and resigned mood (Fig. 13). The Pilgrims' Voice complains of dangers on the road and challenges of the pilgrimage: "Innkeepers cheat us, the English steal."

${ }^{87}$ Identification of cellular elements is adapted from Meade, "Pilgrimage and Postminimalism in POM," 77-83. 
Figure 12. Blocks in "Burgos."

\begin{tabular}{|c|l|l|l|l|}
\hline $1-29$ & $30-41$ & $42-65$ & \multicolumn{1}{|c|}{$66-79$} & \multicolumn{1}{|c|}{$80-222$} \\
\hline Block 1 & $\begin{array}{l}\text { Block 2 } \\
\text { chorale } \\
\text { (Prayer) }\end{array}$ & $\begin{array}{l}\text { Block 1, } \\
\text { canonic } \\
\text { treatment }\end{array}$ & $\begin{array}{l}\text { Block 2 chorale } \\
\text { (Pilgrims' Voice) }\end{array}$ & $\begin{array}{l}\text { Block 3 ostinato plus } \\
\text { multiple upper voice } \\
\text { blocks (melodies) }\end{array}$ \\
\hline
\end{tabular}

\begin{tabular}{|l|l|l|l|l|l|}
\hline \multicolumn{1}{|c|}{$223-252$} & \multicolumn{1}{|c|}{$253-268$} & \multicolumn{1}{|c|}{$269-282$} & \multicolumn{1}{|c|}{$283-290$} & 291-328 & \multicolumn{1}{|c|}{ 329-end } \\
\hline Block 4 & Block 1 with & Block 2 & Block 2 & Block 1 & $\begin{array}{l}\text { Concluding } \\
\text { prayer }\end{array}$ \\
& $\begin{array}{l}\text { ascending } \\
\text { m3 and } \\
\text { altered } \\
\text { harmony } \\
\text { (variant) }\end{array}$ & $\begin{array}{l}\text { (Pilgrims' } \\
\text { Voice) }\end{array}$ & $\begin{array}{l}\text { cadence; } \\
\text { Sighing } \\
\text { block }\end{array}$ & & \\
& & & & \\
\hline
\end{tabular}

Figure 13. II/1-11, Block 1, piano reduction.

Text: "Innkeepers cheat us, the English steal, The devil waits at the side of the road. We trust in remnants, prayers and bones."
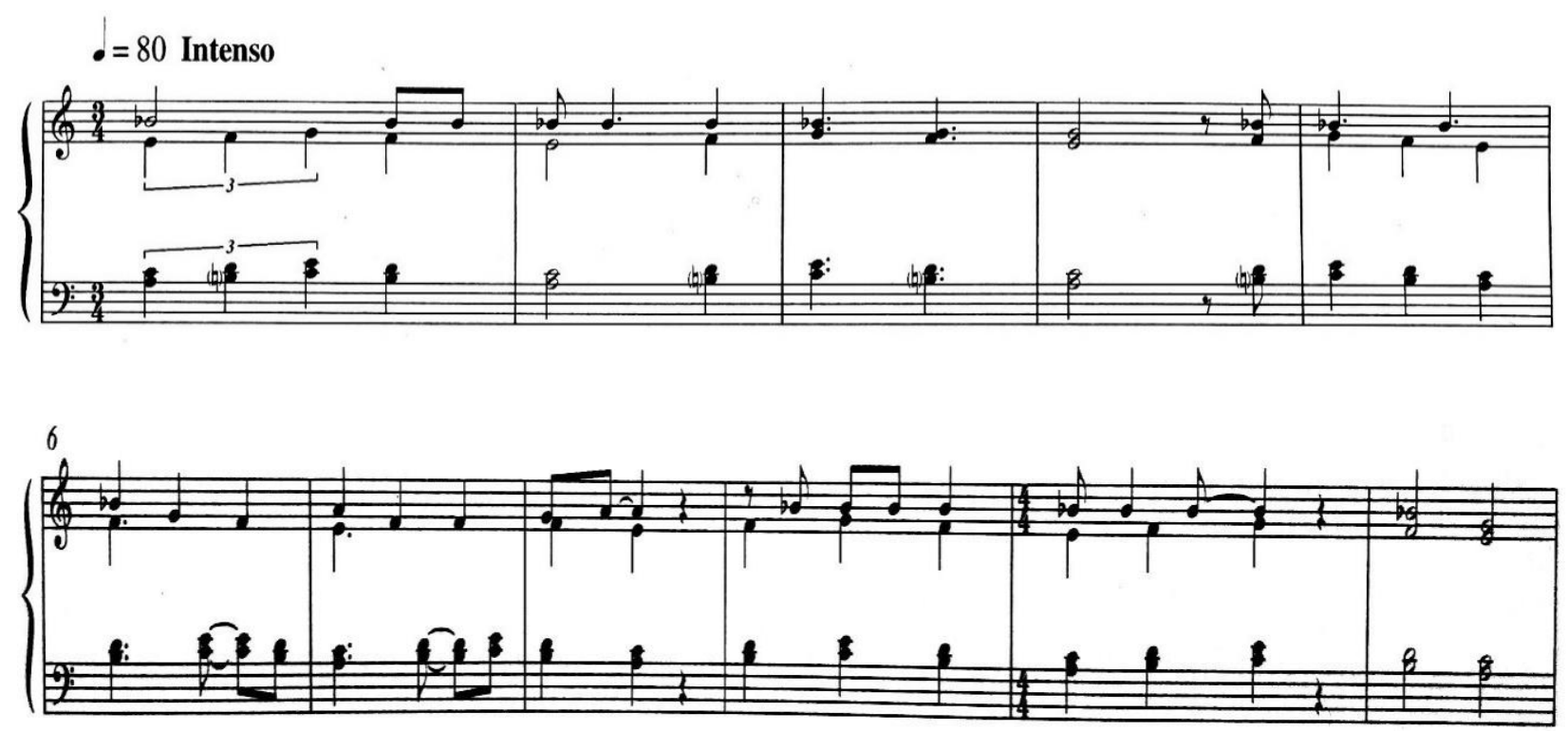

Block 2 starts at $\mathrm{m}$. 30, a homophonic setting with static harmony. It is closely related to Block 1 by its simple $\mathrm{m} 3$ melodic motion, an inversion of the Block 1 dissonance (Fig. 14). As Meade observes, it resembles a chorale, and, in this first iteration conveys a prayer to Saint 
Julian of Cuenca and Santa Casilda. ${ }^{88}$ Blocks 1 and 2 alternate with each other for the first section of the piece. The return of Block 1 at $\mathrm{m} .41$ is set canonically, with lower voices following by three eighth notes the upper voices evoking a hazy, dream-like atmosphere. Block 2 returns at $\mathrm{m} .66$, this time is set to the opening text warning of dangers on the road.

Figure 14. II/31-34, Block 2, piano reduction. Text: "St. Julian of Cuenca, pray for us."

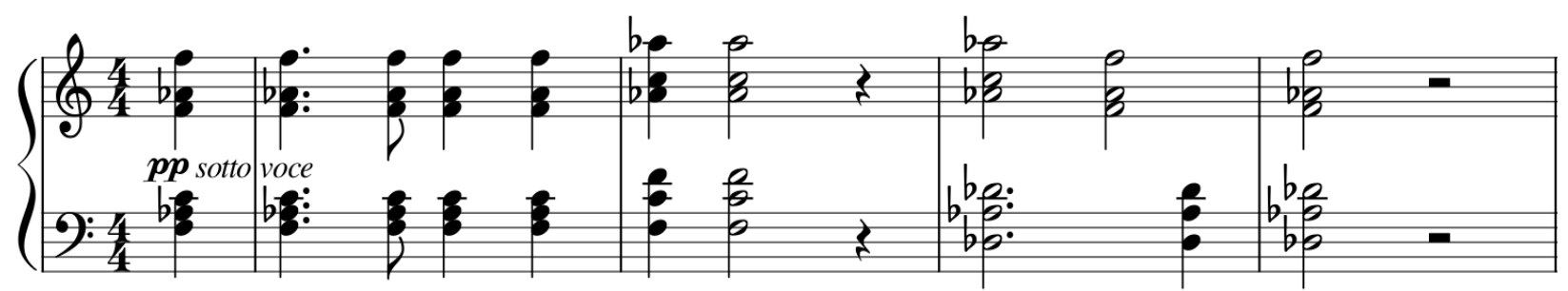

The third block begins in $\mathrm{m} .80$ in the tenor and bass voices and continues (after a climactic transposition in the last several bars) to m. 222, an ostinato that "conjures . . . a pilgrim's tired feet plodding along the path." ${ }^{89}$ (Fig. 15.) Block 3 combines with multiple separate blocks in the upper voices, which are often treated more like melodies (Fig. 16). These nearly all have the miracle cell at their core, with other pitches added.

Figure 15. II/80-86, T, B, Block 3, piano reduction.

Text: "Santiago Peregrino."

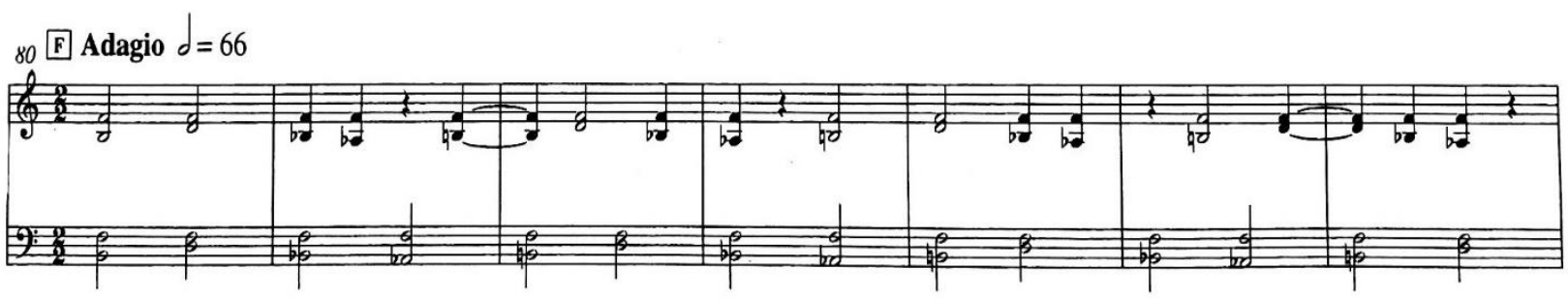

\footnotetext{
${ }^{88}$ Meade, 80.

${ }^{89}$ Meade, 82.
} 
Figure 16. II/156-169, A1-4.

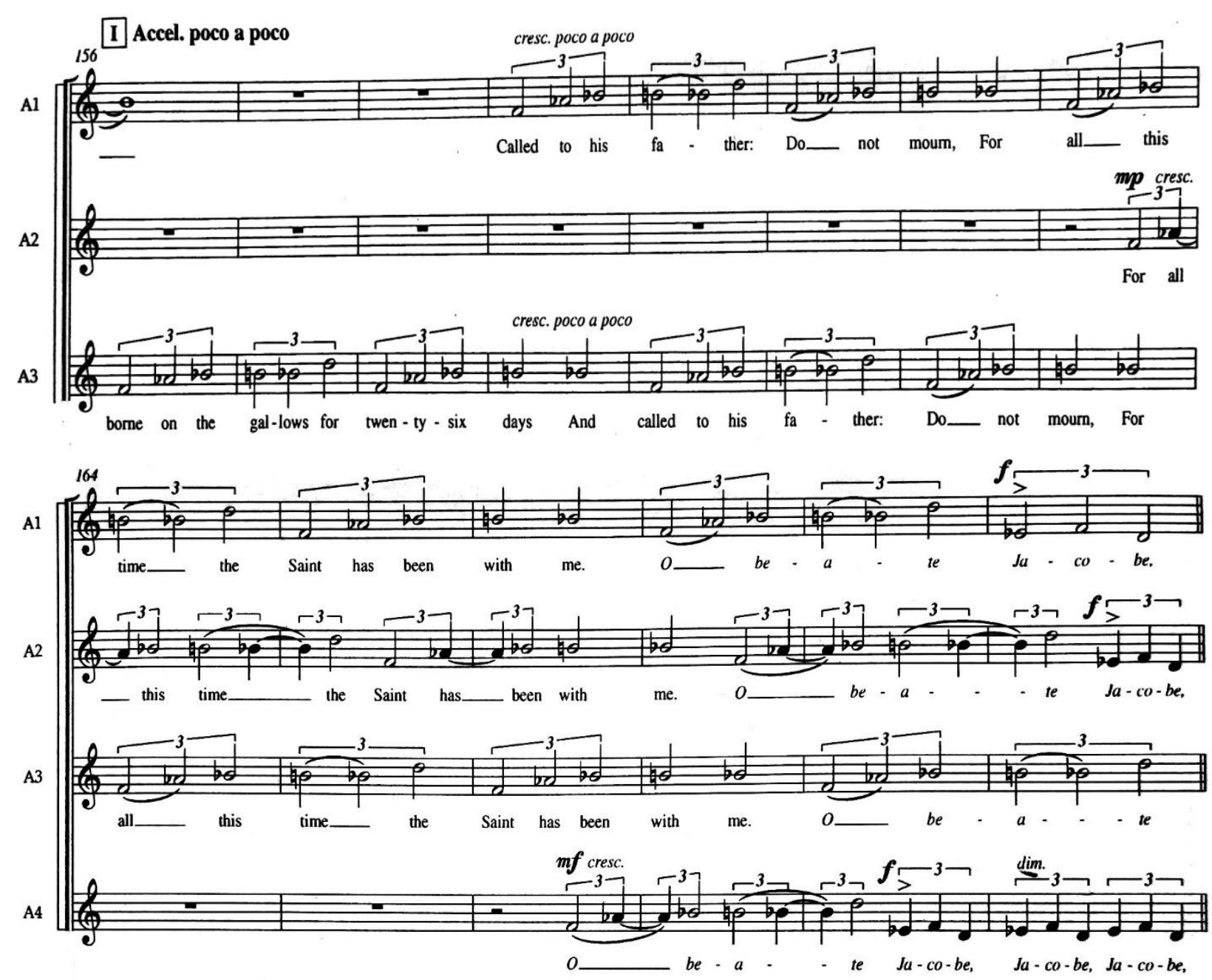

At m. 223, a block of material with dance rhythms (“dance block") makes a brief appearance, consisting of half-step motion between $\mathrm{C}$ and $\mathrm{Db}$ (Fig. 17). Alterations between duple and triple have been common in dance music. Early forms such as the galliard sometimes divided a measure with six quarters into $3+3$ and sometimes $2+2+2$, especially at cadential points. ${ }^{90}$ Dowland's “Can She Excuse” (1597) is one such example. More recently, flamenco forms such as the guajira and the Mexican huapanga move between duple and triple, and, most

90 Alan Brown, "Galliard," in Grove Music Online (Oxford University Press, 2001), doi.org/10.1093/gmo/9781561592630.article.10554. 
famously, “America” from Bernstein's West Side Story contains just such a repeated rhythmic alteration throughout. ${ }^{91}$

Figure 17. II/223-29, Dance Block, piano reduction.

Text: "Sometimes the Saint takes the form of a pilgrim, Sometimes the devil takes the form of a saint. Pray to the Saints and the Virgen del Camino, To save you as she saved the man from Lyon."

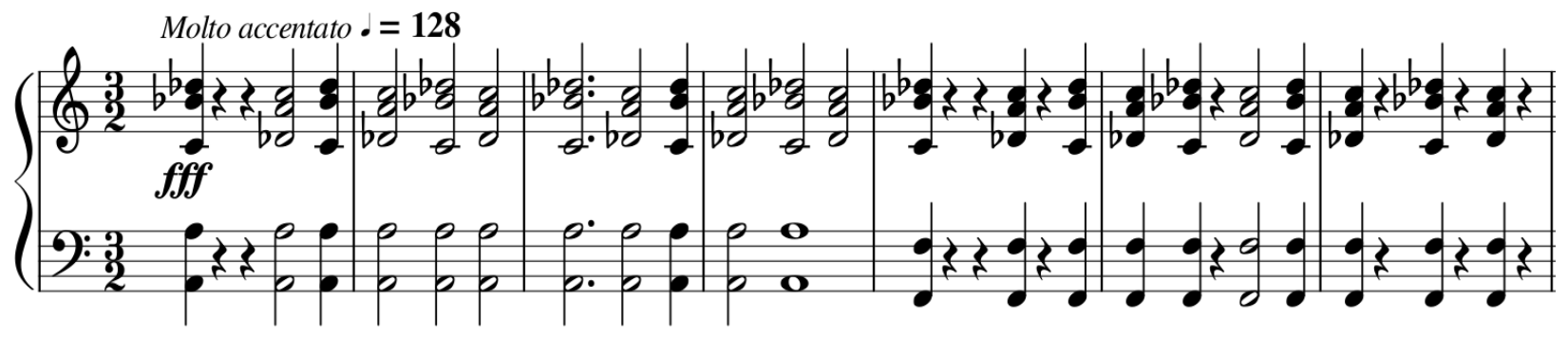

At $\mathrm{m} .253$, a variant of Block 1 includes an ascending $\mathrm{m} 3$ instead of the descending motion of the opening, and with a harsher harmony marked by $\mathrm{m} 7$ leaps in the bass. Block 2 returns at $\mathrm{m}$. 269. Measure 283 starts with a new block of descending half-step motion in the lower voices which accompany the Block 1 variant in unison in the upper voices. In m. 291, Block 1 returns in a form more like its appearance at the opening, and gradually fades away to leave room for a concluding prayer in Latin:

Ora pro nobis, Jacobe,

A finibus terrae ad te clamavi.

Pray for us, St. James, from the end of the earth I cry to you.

\footnotetext{
${ }^{91}$ Israel Katz, "Flamenco," in Grove Music Online (Oxford University Press, 2001), doiorg/10.1093/gmo/9781561592630.article.09780; for more on the origins of "guajira," see William Gradante, "Guajira," in Grove Music Online (Oxford University Press, 2001), 101, doiorg /10.1093/gmo/9781561592630.article.11889; for more on the origins and background of “America," see Nigel Simeone, Leonard Bernstein: West Side Story (London: Routledge, 2017), 101.
} 
At the opening of the movement, the back and forth between Blocks 1 and 2 create something of an aimless wandering with long silences in between as pilgrims complain about hardships on the road, pray for help, and "beat our hands against the walls of heav'n." In this alternation Talbot evokes the changing mood of pilgrims as they make their way.

It is starting at m. 80 that real hardship kicks in and the interaction of varied musical materials creates a stunning musical and emotional impact. Because this extended passage contains matters of keen musical interest it will be the focus of the discussion of this movement. The Block 3 ostinato is established in the bass parts with a trudging 4-beat half note figure which recalls the miracle cell, i.e., the pitches $\mathrm{Ab} \mathrm{B} b \mathrm{~B} \dashv$, plus a $\mathrm{m} 3$ above (D) and, as in the first movement, a m3 below (F) (see Fig. 15). Tenors start together with the basses and sing the same pitches with a diminished rhythm that evokes a steady plodding by pilgrims walking mostly together, but not in lock step. Significantly, the rhythmic variation shortens their motive so that repeated iterations come at a 31/2-beat interval. As a result, the pitches of tenors and basses shift in a phase-type motion reminiscent of first generation minimalist compositions such as Piano Phase by Steve Reich. In this case, once set in motion, the phase shift proceeds without further adaptation and the different pitch combinations bounce against one another in a representation of the toils of the trek.

It is important to notice at this point the significant difference between Talbot's score and the compositional practices of early minimalists. First, the process established is quite a simple one, but more important is the esthetic distance between Talbot and the minimalists. Here, Talbot is not particularly interested in process as a method of composition. Instead, the process is just one component in a larger artistic goal to express the drama of the moment. The process is effective because it serves this dramatic purpose. 
In terms of its expressive power, the canonic construction of Block 3 tells a precise story. In fact, pilgrims do not march together in lock step as in a military parade. At the same time, they are not (musically) ambling along on their own, at their own utterly independent pace and with their own individual footfalls. They are connected by an identical pace and a regular recurrence of rhythmic activity. This kind of writing points out a significant difference between the physical world and the necessities and advantages of representing the physical world through music. While sheer independence might be visually and physically accurate, it would be utterly ineffective musically and, moreover, such portrayal might well miss an essential element of pilgrimage. While it may be true - in the reality of a journey involving multiple individuals that footfalls are independent, each pilgrim is, in fact connected to other pilgrims mentally, emotionally, even spiritually as they join together on their journey. This is the element of “communitas" which constitutes an important aspect of the pilgrimage ritual. As Picasso famously asserted, "Art is a lie that makes us realize truth." 92 By simultaneously connecting and separating pilgrims with this canonic technique, Talbot manages to express, all at one time, the suffering of the journey, the loneliness of a long trip and the emotional connections that pilgrims are developing.

Above the ostinatos are multiple blocks sung by the altos (mm. 87ff.) which describe multiple events in James's life, his return to Spain from Jerusalem, location of his relics and his miraculous works, each following the other with elements of the continuing stories. They sing melodic, triplet-based lines (against duple in the lower voices) but include only the collection of pitches found in the ostinato ( $\mathrm{Bb} \mathrm{B} \mathrm{D} \mathrm{F} \mathrm{Ab).} \mathrm{In} \mathrm{m.} \mathrm{114,} \mathrm{the} \mathrm{altos} \mathrm{add} \mathrm{Eb}$ to the collection when dramatically proclaiming James's miracles (including the gift of a horse and keeping a boy alive

${ }^{92}$ Alfred Barr, Picasso: Fifty Years of His Art (New York: Museum of Modern Art, 1955), 270. 
on the gallows for 26 days). These six pitches, $\mathrm{B} b \mathrm{~B} \vdash \mathrm{D}$ Eb F Ab, contain two iterations of the miracle cell. The line becomes quite angular with almost no stepwise motion, adding to the drama, but then ebbs away, leaving only the tail (m. 125), again the miracle cell (D Eb F), before the $\mathrm{Eb}$ drops out altogether (133) so that the many-fingered stories of events on the road, James's his relics and his miracles can begin anew.

The intensity builds with increased dynamics as, at 156, the two altos (A1/3) sing together, in canon this time, then two additional altos join, also in canon, offset by a half measure from A1/3, tricky because all are singing half-note triplets (see Fig. 16). At the forte in m. 169, the pitch $\mathrm{Eb}$ is added back in, after which the intensity swiftly subsides, leaving the miracle cell tail (Eb F D) from earlier in the movement (presented both in half note triplets and in quarter note triplets that blend the harmony together), m. 170. The ostinato continues in basses 3-4 (B D $\mathrm{Bb} \mathrm{Ab}$ ), with repeated $\mathrm{F}$ in $\mathrm{B} 1-2$, as before (see Fig. 15).

The varied juxtapositions of these musical elements present striking contrasts and interesting interplays from a purely musical perspective. But more than that, they effectively evoke the varied emotions and thoughts of pilgrims as they endure the hardships of the journey but also allow their minds to engage in contemplation. The references to James and to miracles start in a simple, more declamatory style, but become more elaborate each time. The musical fabric becomes more rich and varied; the emotional content more intense. In this way, Talbot expresses the initial simplicity of pilgrims as though they perhaps hear of these events for the first time. Then, as they mull them over in their minds and hearts, they become more engaged, ecstatic even. Once again, pilgrims are not alone in singing their growing ecstasy. They are connected melodically and canonically so that an individual's emotions join with the others. 
At the same time, in a complex, collage-like layering, the ostinato continues, along with its own themes of physical and emotional hardship. Connected to the ecstasy that pilgrims experience as expressed by the alto voices is the necessity of struggle. Indeed, one might even say that, in accordance with the anthropological literature, the suffering of the pilgrims itself makes possible the vulnerability and openness necessary for religious experience, including the appearance of miracles and the resulting ecstasy. ${ }^{93}$

The Eb described above at m. 178 disappears when the hymn (Block 2) returns softly, in the upper voices. This music, prayerful, plaintive, was so lovely when it initially appeared at $\mathrm{m}$. 30 and so it is again now, sung ethereally in the upper voices while the ostinato continues below. And yet the text is no longer a prayer to St. Julian of Cuenca and others. Instead, the text is the exact same words as the trudging, aimless opening: "Innkeepers cheat us, the English steal." What a dramatic transformation. Thus does POM capture the juxtaposition of thoughts and feelings that consume a pilgrim weary from their journey. Weak, distraught, discouraged, pilgrims sing the prayer, they crave holiness, they seek forgiveness and salvation, but these pains and sufferings come sputtering back so that, despite best wishes and fervent desire, their voices can only mouth earthly complaints about hardship, as all they can think about is how they are cheated and robbed. Complete mystical transformation, hinted at earlier in the movement, is not yet possible. By adding these different blocks together at different points in the drama, Talbot is able to express complex and interrelated emotional and dramatic concepts.

Talbot's portrayal of time here is notable. Minimalist music has typically been highly dependent on time as a mode of unfolding presentation and it is sometimes thought that the style

\footnotetext{
${ }^{93}$ See Meade, "Pilgrimage and Postminimalism in POM," 18-19.
} 
"is devoted to making the listener keenly aware of the passage of time." 94 On the other hand, the composer György Ligeti has asserted that temporal relations in his music are converted into spatial ones so that portrayal in music of a "succession of events is a mere exposition of something that in its nature is simultaneous." 95

Talbot here manages to employ both concepts together. On the one hand, the minimalist ostinato (Block 3) is devoted largely to the excruciatingly slow progression of time during lengthy pilgrimage. However, the other blocks have more of a timeless quality - thoughts and ideas that occur all at the same time, or, more likely, are swirling around at various points and times within the consciousness of a pilgrim. Nearly hallucinatory thoughts, the result of suffering on the road, they come and go in a pilgrim's mind, including thoughts about miracles, about the translatio, prayers, fears and warnings. They are sometimes presented successively but as they are mental images, they retain a timeless quality.

The juxtaposition of time-based bodily processes and timeless mental concepts serves a dramatic purpose. On the one hand, pilgrims are bound by time as their physical journey unfolds over a seemingly endless succession of days. And yet, on the other hand, their minds, even without intention, wander over any number of varied and timeless concepts, and that contemplation is perhaps indeed made possible by the hardships of the road. It is in the nature of journey and hardship that a mind may at certain times lose awareness of the passing of time and the physical hardship, but at other times may be able to think of nothing else.

\footnotetext{
94 Bernard, "Minimalist Aesthetic," 1993, 122.

${ }^{95}$ Quoted in Bernard, 122.
} 


\section{B. Text Considerations}

Like the music, the alto text beginning at $\mathrm{m} .87$ is also constructed in an additive manner, with the story unfolding little by little until the full scope becomes apparent. ${ }^{96}$ This interconnection helps to conceal but then ultimately reveal aspects of a pilgrimage in important ways. The reference to the German pilgrim's son who was "hanged as a thief" based on testimony of a local seems at first to fall into the category of dangerous things that could happen on the road - a warning to pilgrims to be careful and look out for "innkeepers" who "cheat." It is connected musically to the first block and expressed with the Pilgrims' Voice. Then, later in the movement, when miracles are more the focus, the case of the boy who survived on the gallows for 26 days is described, with the wonder and ecstasy of that moment. In fact, these two texts arise from the same story - the fifth miracle of St. James, taken from the Codex Calixtinus, in which an innkeeper tried to swindle some pilgrims by accusing them of theft. ${ }^{97}$ After the boy was sentenced to die as a thief, the father continued his pilgrimage to Santiago, but on the return trip discovered that his son was still alive..$^{98}$

Thus, again in accordance with Meade's anthropological study, the suffering described in the Codex Calixtinus is directly responsible for the miracle that follows, and for the pilgrims the complete story offers hope of a potential miracle awaiting them, too, as they continue their journey.

\footnotetext{
96 Tenors and basses continually repeat "Santiago Peregrino" (Santiago Pilgrim).

${ }^{97}$ See Coffey and Dunn, Miracles and Translatio, 22-25.

${ }^{98}$ Coffey and Dunn, 24.
} 


\section{CHAPTER 4: "LEON"}

\section{$\underline{\text { A. Musical Depictions of Light }}$}

The cathedral at León is renowned for its jewel-like light that "seems to have more stained glass than stone, less glass than light." 99 It has been described as the "blonde beauty of Spanish churches, the fairest of all."100 "Towers, flying buttresses, facades, the filigree of the whole ensemble speaks of harmony and balance, with the resulting state of emotional admiration in the visitor's mind."101 Composer Talbot visited the cathedral in preparation for composition and describes the resulting "Leon" movement as a "Lux Aeterna."102

Although pilgrims during the movement announce their progress through various towns and places of rest on their way to León, and won't glimpse the cathedral for several days after leaving Burgos, they start this path, this movement, with a sense of ease. Their burdens are perhaps lightened by a mental image of the cathedral to come, or from growing familiarity with the requirements of travel, growing community with their fellows or growing religious faith. The opening text certainly points to the latter: "Li soleus qui en moi luist est mes deduis, Et Dieus est mon conduis," is from an anonymous $13^{\text {th }}$ century chanson pieuse, a devotional poem similar to the song of the trouvere, ${ }^{103}$ and means, "The sun that shines within me is my joy, and God is my guide."

${ }^{99}$ Georgiana King, quoted in Meade, "Pilgrimage and Postminimalism in POM," 37.

${ }^{100}$ Edward F. Stanton, The Road of Stars to Santiago (Lexington: The University Press of Kentucky, 1994), 131.

${ }^{101}$ Meade, "Pilgrimage and Postminimalism in POM," 38, quoting Alfonso Garcia, The Road to Santiago, ed. Vincent Pastor (León: Edilesa, 1999), 129.

102 Crouch, POM CD Liner Notes, 4.

${ }^{103}$ Herbert H. Hoffman, Hoffman's Index to Poetry: European and Latin American Poetry in Anthologies (Scarecrow Press, 1985), 369; Mark Everist, French Motets in the Thirteenth Century: Music, Poetry and Genre (Cambridge, UK: Cambridge University Press, 2004), 131. 
Like "Burgos," "Leon" is based on layers of sound that interact in unusual ways with each other and the harmonic foundation. The movement starts with a canonic Cm wash (Fig. 18). ${ }^{104}$ Analysis of each eighth note implies a purely functional progression: III-V7-i-V-i-V7-i. But the harmonic rhythm is so fast that the ear doesn't really hear functional harmony. The entire set of pitches in these measures is just C D Eb F G. Voiced the way they are, they could form a gentle cluster. But the pitches are not pressed together simultaneously. Talbot has crafted a thoroughly pleasing balance between functional harmony and a cluster sonority. Like the ostinato in "Burgos," the canon is distinct rhythmically. Here, the canon is in two voices at a time, S1/3 and then S2/4 entering at the interval of 3 beats. The harmonies move so swiftly that the ear hears something like the shimmers that the eye sees when a prism twists in the light, perhaps the same shimmer that Talbot experienced when he walked through the shifting light of the León Cathedral. This effect is enhanced by placing the harmonies in the soprano voices, pianissimo.

Figure 18. III/1-4. S1-4.

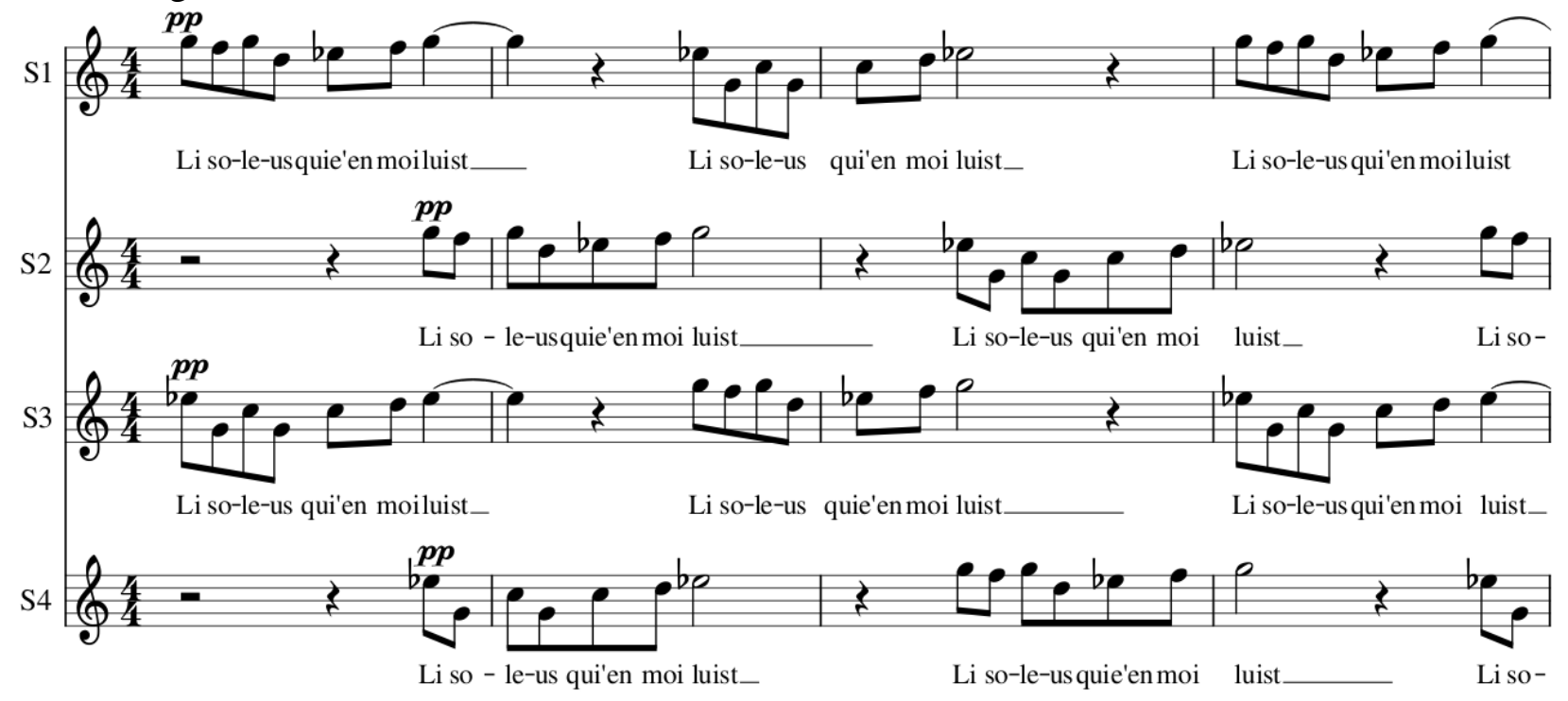

104 Jeffery Goolsby describes the melodic figure as a double cross. Goolsby, "Pilgrimage Triptych," 28. 
Glorious León Cathedral light is one thing, but the pilgrims still must make their way. This they do with the Pilgrims' Voice entering at $\mathrm{m}$. 4, with tenors and basses singing long notes of a cantus firmus which enters in $4 / 4$ time so that the ostinato plays against it (Fig. 19). The suffering and plodding of "Burgos" is gone. Here pilgrims float on the path, the long notes carrying them along with growing faith as well as hope for what awaits. The technique evokes much earlier compositional styles and thus generates an emotional and musical connection with pilgrims who have taken this path in prior centuries. It also expresses the patience required from pilgrims, particularly those of the modern day, who must slow their pace both from the speed of the world they have left behind but also in order to keep a pace that can be sustained over many long days.

Figure 19. III/4-19, T3-4; B1-2. Text: "We have walked/In Jakobsland:/Over river and sheep track."

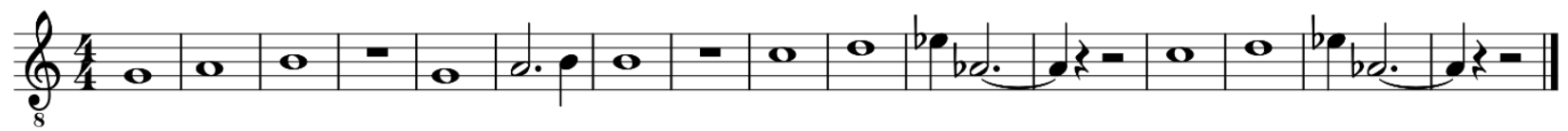

The cantus firmus appears to follow traditional rules of melodic minor, in accordance with the established $\mathrm{C}$ minor, with a gradual ascent that evokes continuing motion. However, this is open to interpretation, because it can also be heard as G major, starting, as it does, on G and proceeding up the scale, G A B C D. In this way it immediately adds to the color, as neither A nor B appear in the ostinato, and together they create something of a bitonal freshness to the passage. When the cantus firmus reaches its $\mathrm{Eb}$ apex (an ascent it makes twice), and then jumps downward to $\mathrm{Ab}$, it also, within the key of $\mathrm{G}$, seems to shift to develop scale relationship ideas that were present in the first two movements. That is, in transitioning to $\mathrm{Eb}$ and $\mathrm{Ab}$, we now must confront the question of whether we have shifted to a Spanish Phrygian mode, or are simply back 
to $\mathrm{C}$ minor. As Talbot has done throughout the piece, the music emphasizes half-step motion between the first and second scale degrees, here $\mathrm{G}$ and $\mathrm{Ab}$ (between $\mathrm{E}$ and $\mathrm{F}$ in earlier Phrygian examples), as well as between the $5^{\text {th }}$ and $6^{\text {th }}$ scale degrees, here D and Eb. Notably, the phrases conclude with the miracle cell, this time adding a M3 below (C D Eb $\mathrm{Ab}$ ) instead of $\mathrm{m} 3$ in iterations of the first movement, a somewhat haunting effect. A monochromatic cantus firmus tail continues, splitting into two lines and ultimately suspending on a tritone at $\mathrm{m}$. 24 , leaving a dreamy half cadence.

Two obscure references benefit from some explanation. The description of walking by "hermit's cave" (m. 22) is a reference to the medieval hermit Pelayo, who is reputed to have rediscovered the tomb of St. James. ${ }^{105}$ The English name "James" is a modern descendent of Latin Iacobus, originally derived from Hebrew. Thus the reference to "Jakobsland" (mm. 9-10) refers directly to the pilgrims' travels through James's northern Spain. The use of the Hebrew may also connect pilgrims to the journey of the Jewish people out of Egypt. ${ }^{106}$

\section{B. Modal Writing and Rhythmic Shifts}

There is significant modal writing here, as in the other movements. At m. 36, a modified entry of the opening ostinato alters the mode to C Dorian. A significant rhythmic shift also comes into play. Talbot augments the eighth-note motion to dotted sixteenths, m. 38. Eighth-note motion quickly returns (48), and the altos then join the ostinato in quarter notes (Fig. 20-21). Sopranos augment to dotted sixteenths establishing a 4:3 relationship against quarter notes, and then sopranos augment again to quarter notes just as altos augment even further to dotted

\footnotetext{
105 See supra at p. 35 .

106 Meade, "Pilgrimage and Postminimalism in POM," 90.
} 
quarters, bringing the section to a gradual halt (Fig. 22). The spinning prism gradually slows until it has stabilized on an F major triad (m. 55).

Figure 20. III/41-45, A3-4, T1-2, B1-4.

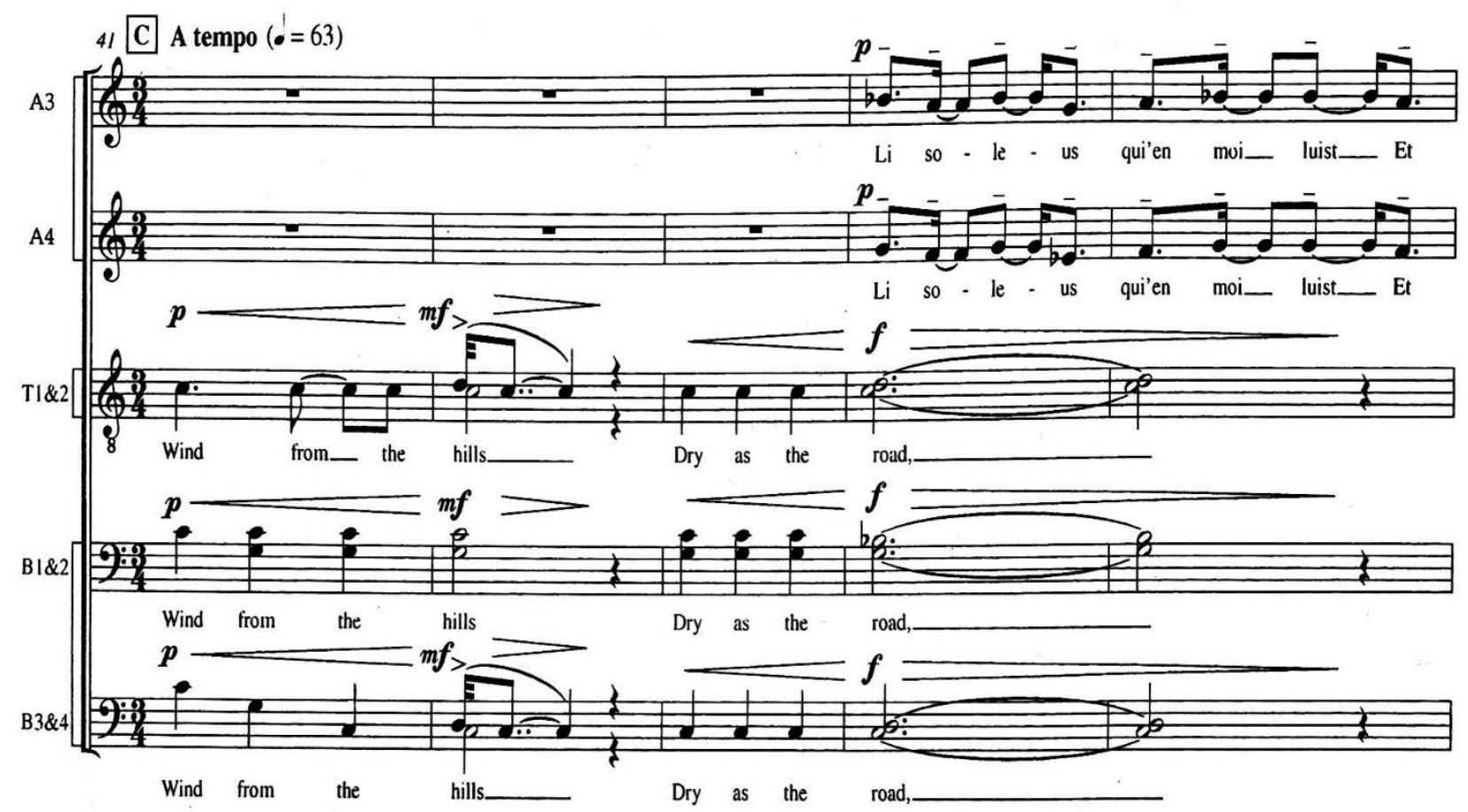


Figure 21. III/46-50.

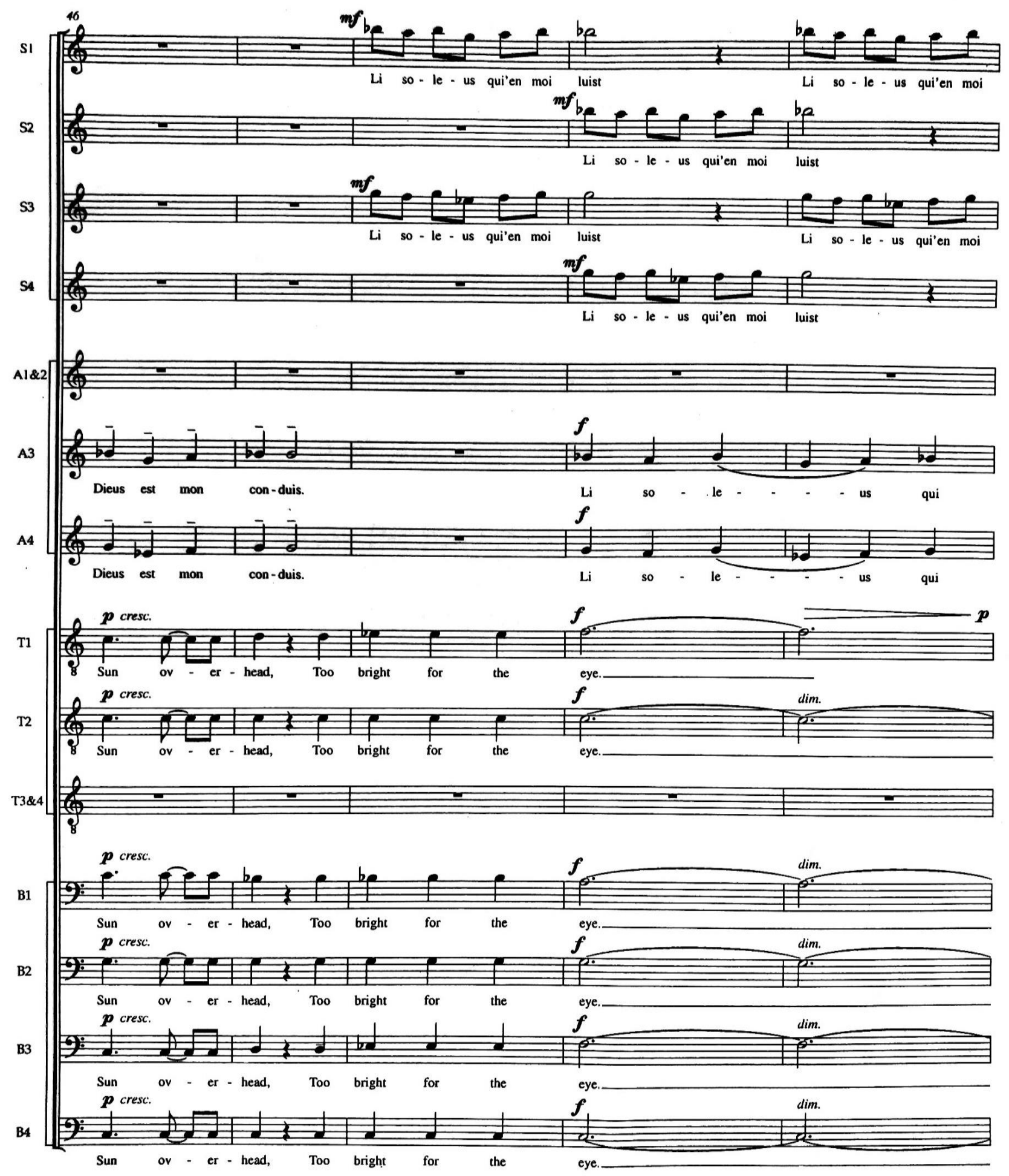


Figure 22. III/51-56, piano reduction.

Text: "Li soleus qui'en moi luist/Et Dieus est mon conduis."

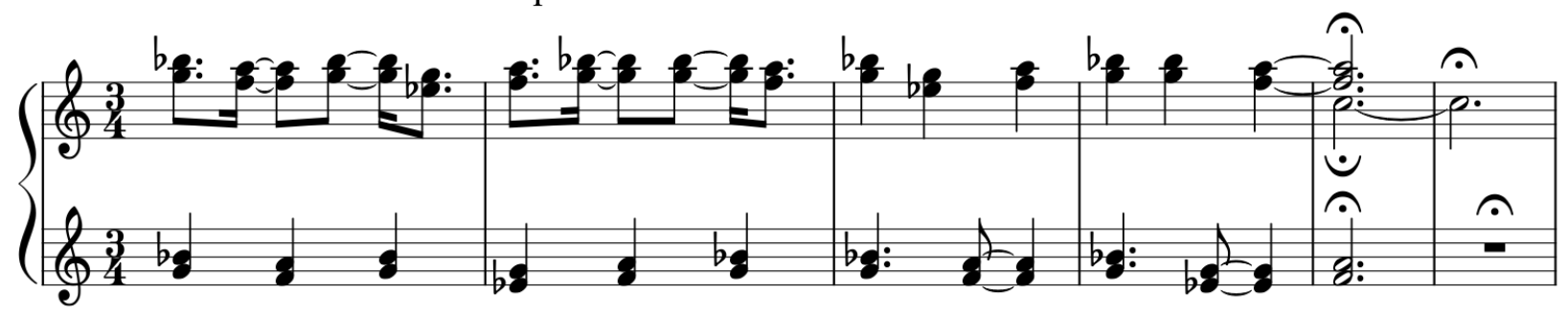

Meanwhile, tenors and basses, in the Pilgrims' Voice at m. 41, have been rather statically describing the harshness of the journey ("Wind from the hills,/dry as the road") (see Fig. 20). The presence of the sopranos and altos make the mood more dream-like, with their constant flowing motion in four against triple meter of the tenors and basses. The travel seems less burdensome and more mystical than the arduous road to Burgos.

Striking are the changing effects Talbot achieves here without significantly altering pitch or harmonic content. For example, C Dorian was introduced at m. 36, with a wash of sound that included all the pitches in the scale, save D. The effect, entrancing and ethereal, makes continuing pilgrim travel seem otherworldly. In $\mathrm{m} .49$, the basic pitch content remains the same, but 1) the durations are lengthened through augmentation so that more are simultaneously heard as clusters; 2) sopranos take the ostinato up an octave, increasing the intensity; 3) lower voices carry more of the clustered pitches (CFGA at 49) making them more audible and dissonant; and 4) dynamics increase (see Fig. 21). The effect here, still magical, but with greater intensity, evokes the sun, "too bright for the eye," and then subsides again, with an uneven ritard approximated by increasingly augmented rhythms, like multiple spinning lights which each at its own pace slows and then comes to rest. 


\section{Shifting Halo and Tertiary Harmonic Motion}

Throughout the movement, Talbot gently transitions from one section to another, allowing ample time for pause and reflection through silence, and relying on smooth transitions, often through tertiary harmonic motion. See, e.g., mm. 27, 40, $55(\mathrm{C}-\mathrm{Ab}), 72(\mathrm{~Eb}-\mathrm{Cb}) 138(\mathrm{C}-$ F (non-tertian)). At 57, Talbot uses a common tone to pivot to Ab (Fig. 23, see Fig. 22 for the pivot). The tertiary relationship between $\mathrm{C}$ and $\mathrm{Ab}$ yields an openness, like opening a new door to the next section, and without the pull and tension that traditional modulation to a dominant might create.

Figure 23. III/57-64, S5, A1-4; T1-3.

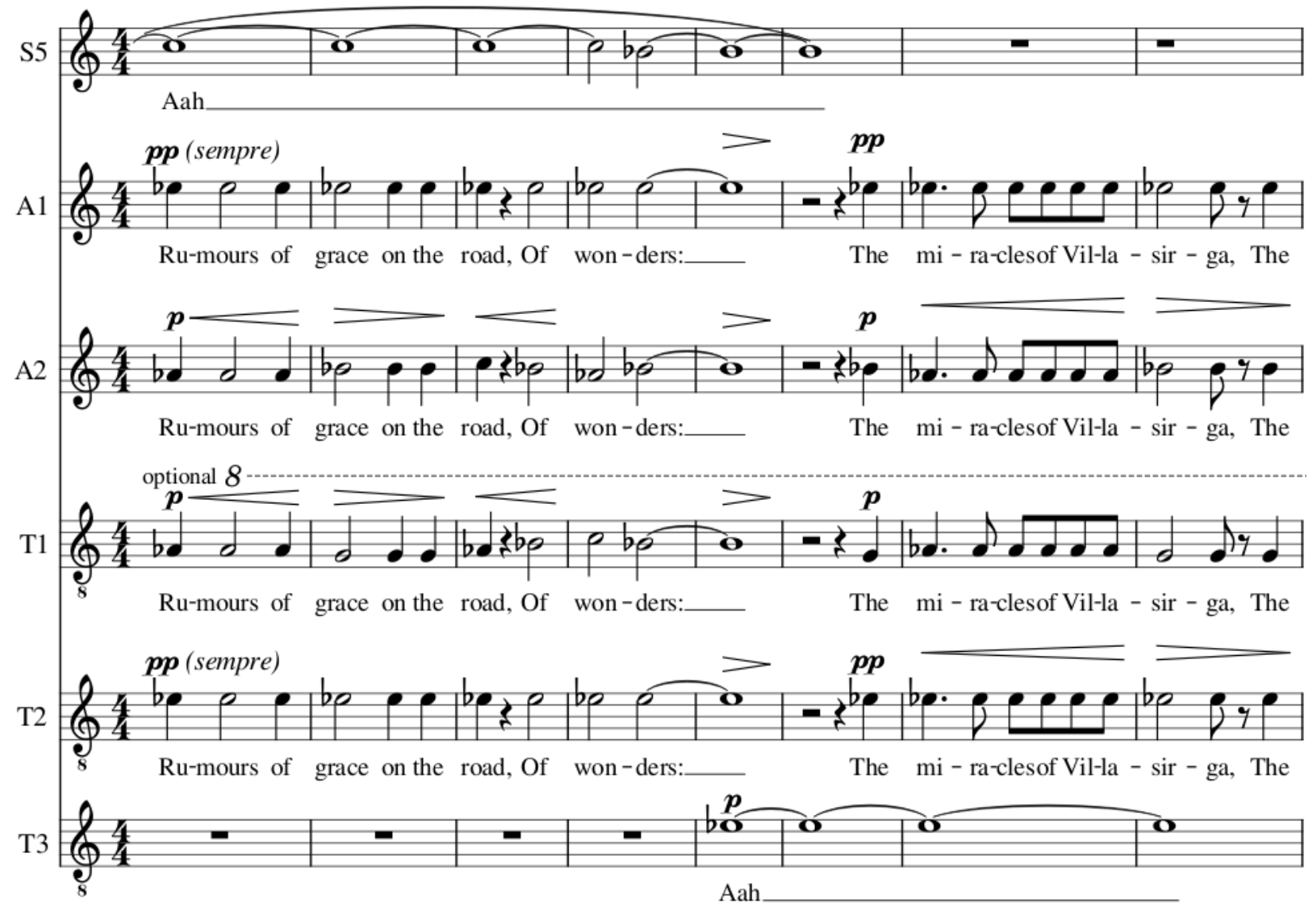


And what an open door this is. The common tone $\mathrm{C}$ is joined by $\mathrm{Eb}$ above and below, while the inner voices fluctuate between $\mathrm{Ab}$ and $\mathrm{Eb}$ harmonies. This $\mathrm{Ab}$ major halo contrasts with the moving ostinato of the previous section and generates a profound stillness as the voices introduce "rumors" of grace and wonder and begin to turn them over in their minds.

Some references in the text require further explanation. First, the reference to miracles of Villasirga is to miracles performed in what is now the city of Villalcázar de Sirga, slightly off the main Camino path between Burgos and León. The $13^{\text {th }}$ century Church of Santa Maria la Blanca there is frequently visited by pilgrims. According to Medieval Spanish scholar Jessica Knauss, fourteen miracles by the Villasirga Virgin are recorded in the Cantigas de Santa Maria, a $13^{\text {th }}$ century manuscript primarily consisting of Marian miracles. ${ }^{107}$

In addition, the reference to the "Apostle on horseback" is to Miracle 4 set forth in Book II of the Codex Calixtinus. This miracle, one of James's most famous, involves thirty pilgrims traveling the Camino in $1080 .{ }^{108}$ Twenty-nine of the pilgrims swore an oath of loyalty to their companions during the journey, but one declined to do so. During the pilgrimage, one of the pilgrims fell ill and progress slowed significantly as the pilgrims helped their companion. Finally, tired of the effort, they left the sick pilgrim at a town and proceeded on their journey, except for the one who had failed to swear allegiance, who stayed behind to care for him. Nonetheless, the sick pilgrim died and, because of his virtue he "fell into the sleep of paradise ...

107 Jessica Knauss, "Villalcázar de Sirga: The Miracle Worker," Jessica Knauss, Spain, Middle Ages (blog), January 27, 2019, jessicaknauss.blogspot.com/2019/01/villalcazar-de-sirga-miracleworker.html; Jessica Knauss, "Villalcázar de Sirga: The Miracles," Jessica Knauss, Spain, Middle Ages (blog), January 22, 2019, jessicaknauss.blogspot.com/2019/01/villalcazar-de-sirgamiracles.html.

$\overline{108}$ Coffey and Dunn, Miracles and Translatio, 18. 
with Saint James leading the way." 109 The healthy remaining pilgrim, now terrified - due to loneliness, the presence of the body and the dangers of the road - cried out to St. James, who appeared to him as a rider. The rider took the body and the healthy pilgrim to Santiago, completing the challenging twelve-day journey in a single night. "Ask the canons at the cathedral to bury the pilgrim," said the rider, "and when you return to León you will meet your faithless companions. Tell them that Saint James is unhappy with them and that they must do penance for their sins." 110 The dumbfounded pilgrims sought and received their penance at León and successfully completed their journey. ${ }^{111}$

\section{Arrival at Eb Major and Return of the Canon: Transposition Technique}

A progression by thirds $(\mathrm{Eb} 7-\mathrm{Cb}-\mathrm{Abm})$ leads to a glorious plagal arrival on $\mathrm{Eb}$ major at m. 79, where the ostinato returns (Fig. 24). Again striking in Talbot's writing is that the return of the canon in A3-4 and T3-4 remains in the original key (here, $\mathrm{C}$ minor) despite the modulation of the underlying harmony. In the common practice period, a change in tonality is ordinarily accompanied by melodic transposition. Here, however, Talbot has designed the ostinato both to shimmer in the upper voices in $\mathrm{C}$ minor at the opening and now to complement the utter relaxation and arrival in the relative major. The ostinato does not change keys. He also shifts the ostinato to the inner voices.

${ }^{109}$ Coffey and Dunn, 20.

${ }^{110}$ Coffey and Dunn, 20.

${ }^{111}$ Coffey and Dunn, 20-21. The days required for travel match the $12^{\text {th }}$ century travel time as specified in Book V of the Codex Calixtinus. Coffey and Dunn, 21. 
Figure 24. III/79-84, piano reduction.

Text: "Jakobsland"

Tempo primo $(d=58)$

A3-4,T3-4: "Li soleus qui'en moi luist."

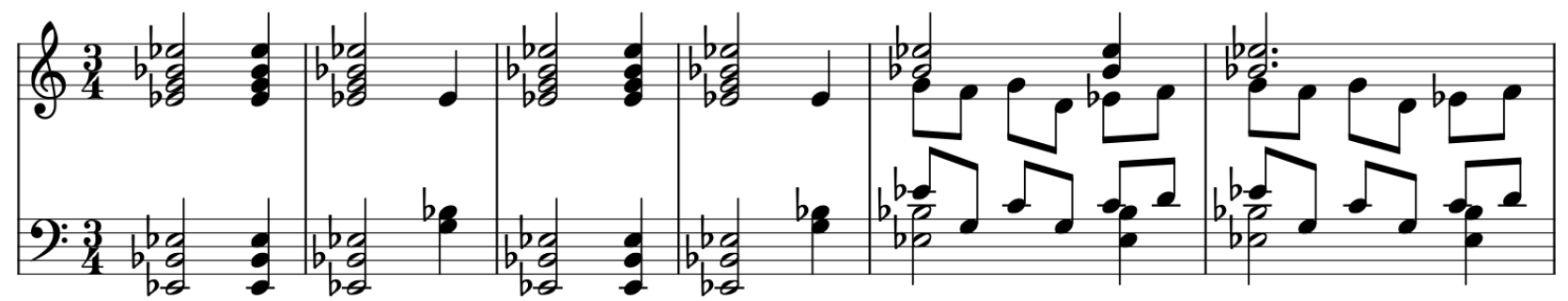

In m. 89, Talbot alters the colors once more, this time shifting the ostinato of the opening to the lower voices while the sopranos carry the cantus firmus (Fig. 25, see Fig. 19 for full melody). This inverted texture technique, common in British compositions of the Tudor period, helps generate continued interest and variety. ${ }^{112}$ The Pilgrims' Voice recites place names along the path.

Figure 25. III/89-92, piano reduction.

Text: S: "Through the Gothic Fields"

A, T: "Li soleus qui'en moi luist"

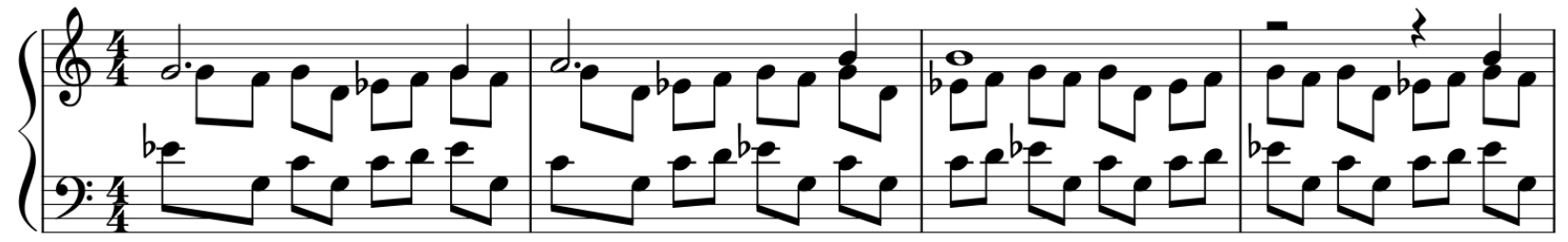

Throughout this movement, Talbot generates an elaborate and effective build-up of drama and tension without the pull of functional harmony. Instead, he builds drama by judicious use of other musical elements, particularly through additive processes. As the cantus firmus starts its ascent to the apex, two tenor voices join, an octave lower. At the repetition of the last cantus firmus phrase a bass voice joins, so that the cantus firmus now appears in three octaves

${ }^{112}$ In addition, allowing a minimalist wash to continue beneath a soaring melody above has become something of a hallmark of Talbot's style (Breckenfield, "Path of Miracles Review"). 
against the continuing ostinato in the inner voices. The lower voices continue with the tail, $\mathrm{mm}$. 105-120, but this time the tail repeats four times, with a slow-moving repetitive mantra: "Each day the same sun ..." The low basses split off dreamily, not in time with the others, and continue down the scale. This treatment serves to emphasize the length of the journey and the pilgrims' trance-like state. As the basses descend, they do not wind up in suspended animation (recall the tritone at the analogous spot in m. 24). Instead, they continue the descent all the way to a glorious Db major triad (m. 119), the foundation of the next section's Lydian mode.

Meanwhile, the ostinato continues at m. 105 (as at m. 89, see Figure 25), adding a quarter note augmentation in the upper register, also in canon. Talbot has piled three blocks on top of each other - the augmented ostinato in upper voices, continually moving ostinato in the inner voices, and slow, repeated cantus firmus at the bottom. And this section also includes yet another key center over which Talbot lays the unchanging ostinato. The lower voices remain almost motionless on F7, stretched and repeated as noted. The effect is more bitonal and dreamy, one can almost feel the sun and see the hazy images on the road, fading in the heat of day.

\section{E. The Shift to Lydian Mode and Half-Step Modulation from Db to D Major}

The next section is introduced with another third relation modulation as the Fm7 harmony moves to Db Lydian mode in m. 119 (Fig. 26). The ostinato is the modified version from m. 36. Once again, Talbot's transposition technique is worth closer examination. In comparison with the material at m. 36, m. 119 does in fact involve transposition (and slight alteration) of the ostinato in relation to underlying material. But the interval of modulation differs so that the relationship to the underlying harmony is not the same as it was at 36 . To recall, at 36, the ostinato carries the pitches $\mathrm{Eb} \mathrm{F} \mathrm{G} \mathrm{A} \mathrm{Bb}$ and thus is crucial in establishing that 
section's C Dorian harmony (occupying scale degrees 3456 7). Here the ostinato has Db Eb F $\mathrm{G} \mathrm{Ab}$, the first five scale degrees of the new Db Lydian scale. Reimagining the possible sonorities of these blocks of sound reveals remarkable new colors. Beneath the ostinato, Talbot introduces a wrenching sigh on "quam dilecta," ("how lovely") (Db C Bb Ab G), a figure which carries the miracle cell from the first movement twice ( $\mathrm{B} b \mathrm{C} \mathrm{Db}$ and $\mathrm{Bb} \mathrm{Ab}$ G). Starting with the altos in $\mathrm{m} .121$, this motive is picked up by other voices, then expanded, and finally rhythmically augmented in a descent which comes to rest pianissimo on unison middle $\mathrm{C}$.

Figure 26. III/119-123, piano reduction.

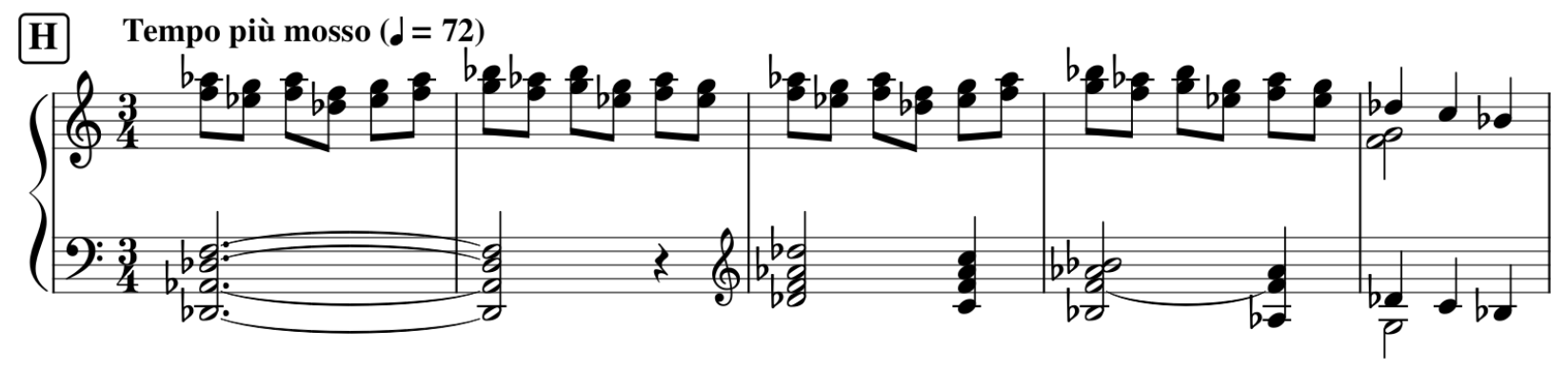

As the C continues at 139, an atmosphere of stillness pervades, and next follows one of the most inspired moments of the piece. To this point in the journey, pilgrims at the outset formed their goals; they have learned about James and how he suffered; and have learned about his miracles. And they, too, have suffered. But now, at this moment, arising out of a deep quiet, pilgrims realize that, regardless of their individual circumstances, "Here is a miracle. That we are here is a miracle." Through the power of their journey, pilgrims have grown to realize that the most obvious of miracles is their own existence. The text is declaimed in the low register of the upper voices while the lower voices maintain an F C drone. The melody starts on unison F and expands outward on "miracle," but only by a M2 (to G4 in S1 and down to Eb4 in S3). On a 
second attempt, the same change happens, and then recedes. The magic of this moment is that the simplicity of the pilgrims' realization - existence is a miracle - is matched by the simplest musical element: slow movement of a M2 can still be filled with wonder. Just as the word "miracle" arrives a second time (146), the m. 36 version of the ostinato appears again, but over F this time and again with rhythmic augmentation (Fig. 27).

At m. 160 the single, chant-like voice, intoned over a sustained four-note chord, recalls the harsh Greek chant from "Roncesvalles." (Fig. 28.) Unlike the first movement, however, the repeated $\mathrm{B} b$ here is consonant with the underlying $\mathrm{B} b$ second inversion harmony in the lower voices which serves as its foundation. Like the "Roncesvalles" chant, phrase cadences carry the miracle cell, but here end with an adaptation - the addition of a M3 below resulting in a sighing descending fifth at the end, $\mathrm{Bb} \mathrm{C} \mathrm{Db} \mathrm{Gb}$. 
Figure 27. III/146-150.

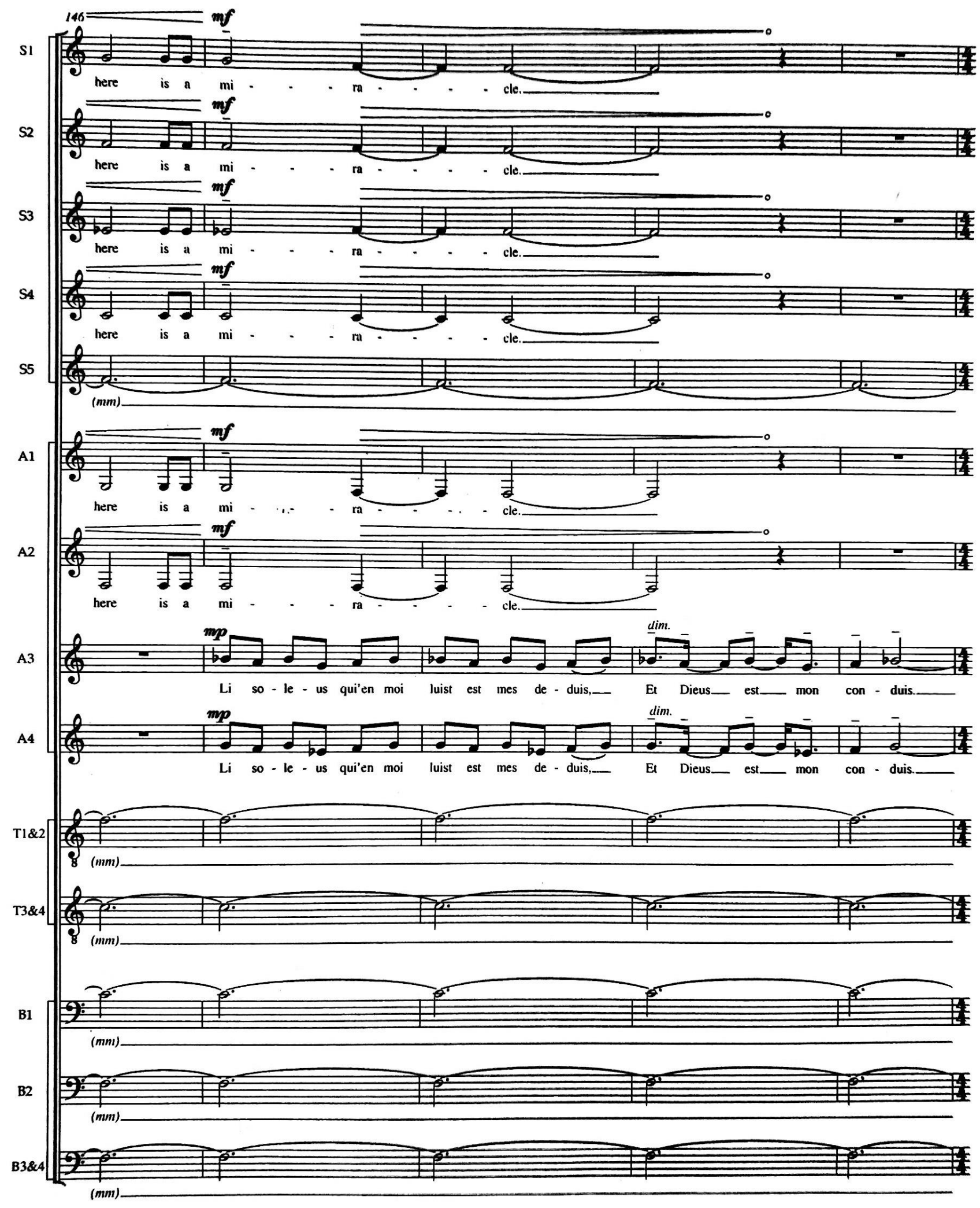


Figure 28. III/160-163, S5.

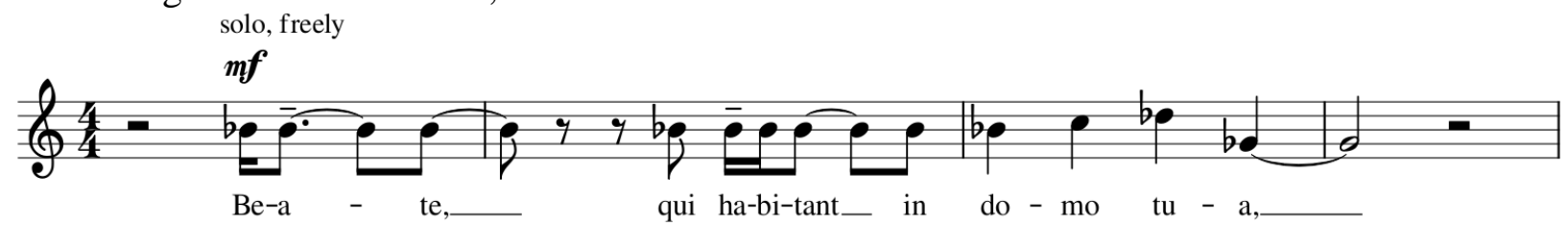

At m. 177 the opening ostinato returns again, this time transposed to what one might think of as B minor (in accord with its function at the beginning of the movement), but instead it plays a different role in relation to the underlying harmony: D major, anchored by a low-threevoice pedal. Here the ostinato, with B C\# D E F\# , emphasizes the strong D major harmony (thus it is similar, though transposed, to the writing at m. 83). Finally, despite the feeling that we have arrived at a final major key, the movement doesn't fully resolve, as the C\# E combination, which we expect to lead to D and F\#, doesn't quite get there, leaving us suspended in the stillshimmering D9 light of the León cathedral (Fig. 29).

Figure 29. III/179-184, piano reduction.

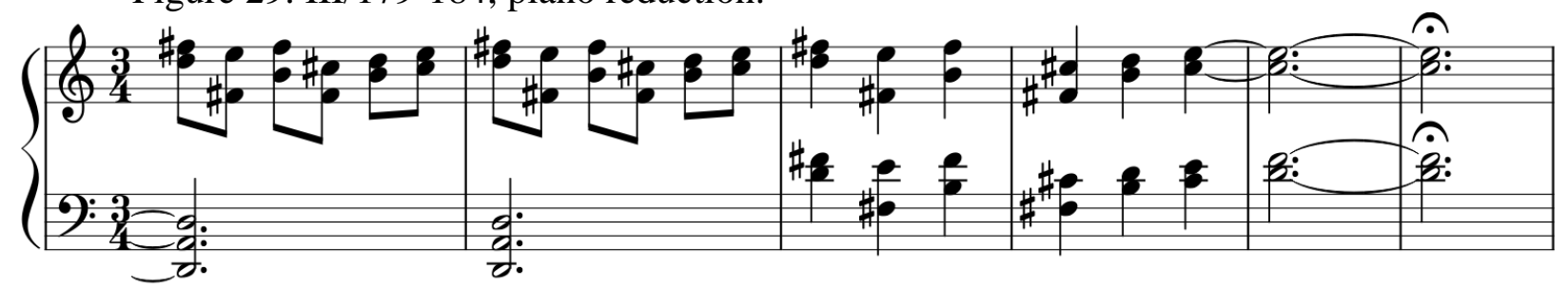

It is instructive at this point to re-examine this movement and the number of different ways that Talbot alters the sonic landscape while still retaining the same basic musical materials (Fig. 30). 
Figure 30. "Leon" Ostinatos.

\begin{tabular}{|c|c|c|}
\hline Measure & Underlying Harmony & Ostinato construction \\
\hline 1 & $\mathrm{Cm}$ & $\mathrm{Cm}$ \\
\hline 36 & C Dorian & $\mathrm{Eb}$ (altered motive) \\
\hline 83 & $\mathrm{~Eb}$ & $\mathrm{Cm}$ \\
\hline 119 & Db Lydian & $\mathrm{Db}$ (altered motive) \\
\hline 146 & $\mathrm{~F}$ & $\mathrm{~Eb}$ (altered motive) \\
\hline 177 & $\mathrm{D}$ & $\mathrm{Bm}$ \\
\hline
\end{tabular}

One way of understanding the number and variety of these sonorities is to recall the original conception of this movement as a "Lux Aeterna." Each of the stained glass windows of the cathedral, each of the shifting ostinato-based harmonies, reveals something like a divine light, but each also carries its own individual brilliance. 


\section{CHAPTER 5: "SANTIAGO"}

\section{$\underline{\text { A. Additive Techniques Build Drama }}$}

Singer Crouch aptly describes the mood and progress of the "Santiago" movement:

The temperature cools, the altitude rises and the rain falls.

Towns pass by like shadows as the road seems to climb and climb, though Leon's contented mood lingers. There seems no doubt that the journey will end, and at the first sight of Santiago, miles down from the summit of Monte de Gozo, the music initially draws inward, before bursting out in an explosion of joy. The Pilgrims' Hymn is heard again, performed with the reverence and reflection of one who has finished such a long journey, and is quickly transformed into a spring revel. ${ }^{113}$

Talbot's evocation of these varying moods at each step along the path is a marvel of the composer's craft. "Santiago" begins with the Spanish Phrygian theme from the first movement, which now feels like an old friend, made perhaps even easier by transposition a bit lower, to C\# rather than $\mathrm{E}$, dropping a few ticks on the metronome and eliminating the pointed accents. Also notable about the ease of this re-appearance is whence it comes. In the first movement, the theme entered immediately after piercing half-step motion between B and C, especially the Greek recitative starting at $\mathrm{I} / 26$. Thus, the recurring $\mathrm{B}$ and $\mathrm{C}$ that appear in the first movement theme carry a remembrance of that pain.

By contrast, the previous material in "Santiago" is the conclusion of "Leon," with its brilliant piano, upper register shimmer of light (see Fig. 29). The unresolved C\# and E sound there like they want to move to $\mathrm{D}$ and $\mathrm{F} \#$, but they remain in suspended animation. In

${ }^{113}$ Crouch, POM CD Liner Notes, 4-5. 
"Santiago," the C\# from "Leon" becomes the central pitch and the theme's half-step motion between $\mathrm{C \#}$ and $\mathrm{D}$ becomes an easier motion between what we heard as the leading tone and the tonic in the previous movement (Fig. 31). Similarly, the E, the uppermost shimmer from "Leon," appears again in "Santiago" in the motion between E and E\#. All of the pitches of the final chord in "Leon" appear in the C\# Spanish Phrygian scale that starts "Santiago." In contrast to the repeated pain of the theme in "Roncesvalles," "Santiago" carries the ease of this pivot chord modulation.

Figure 31. IV/1-9, piano reduction.

Text: A4: "The road climbs through changing land/Northern rains fall/On the deepening green of the slopes of the valley."

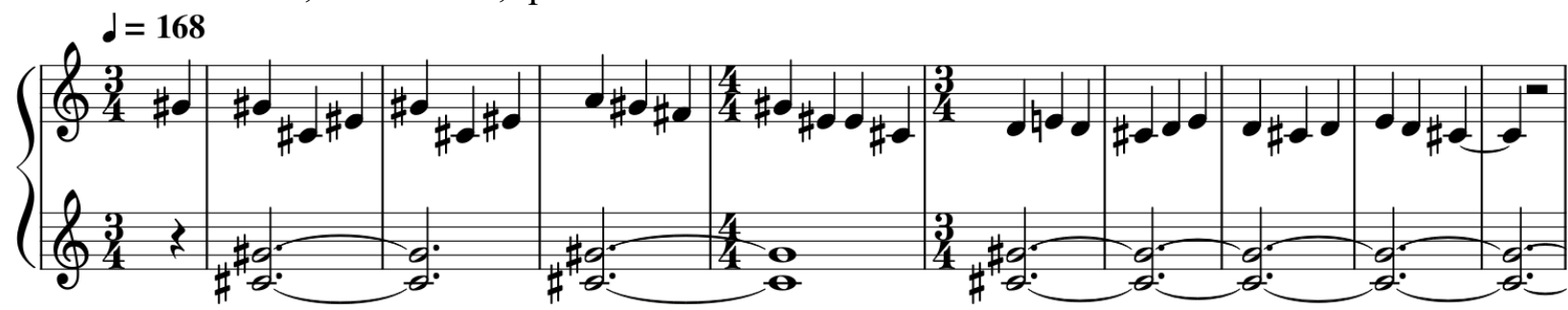

Also notable about this new entrance, now that pilgrims are about to reach their final

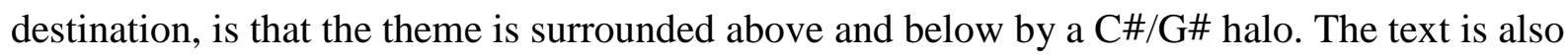
well-expressed by this imagery: "Beate qui habitant. .." comes from Psalm 84: "Blessed are they that dwell in thy house." The halo solidifies the C\# tonal center and the other elements of the first movement recur, including the half-step motions - touching $\mathrm{G} \#$ and $\mathrm{A}$ (5 and 6 of the $\mathrm{C \#}$ Phrygian scale) and the oscillation between C\# and D at the tail of the theme (1 and 2 of the scale) and between E and E\# (the altered 3 of Spanish Phrygian). Almost immediately, however, at the first repetition of the theme (m. 13), POM moves the halo to A and E, thus generating a different sonic prism through which to hear it. A and E are both within the C\# Spanish Phrygian 
scale, but the E\# of the opening phrase might also be heard as bitonal, with a new A foundation causing a shimmer against the separate $\mathrm{C \#}$. Under both hearings, the effect is a magical easing, as the descent to $\mathrm{A}$ and E now generates a bright AM7 harmonic sonority enriched by the melodic E\# but not dominated by it. Now the G\#/A motion is between 7 and 1; C\#/D are 3 and 4; and $\mathrm{E}$ and $\mathrm{E \#}$ are 5 and \#5 (or b6). So, astoundingly, the melody can continue unchanged as the pilgrims walk on, but the colors shimmer in slightly different ways at different points along the path. ${ }^{114}$ Although "the road climbs and climbs," pilgrims remain filled with the multi-faceted light from León and carry their burdens with ease.

Talbot also treats the theme's tail with somewhat more richness than in "Roncesvalles." At $\mathrm{m} .33$, the tail accompanies the theme for the first time, and at 37, multiple repeated iterations create a series of successive seconds. At 49 , the interweaving tail and the continuing halo are joined by a block of sopranos chanting words of praise ("laudabant te") in a major third (A/C\# over the $\mathrm{C} \# / \mathrm{G} \#$ halo). They are then joined, after the halo drops away, by a new cantus firmus in B1-2 which primarily outlines a D major triad. The clustered harmony and major intervals and triads evoke ease and confidence.

Equally important is the additive harmonic build-up to the next climax. At 53 when the halo disappears, the only pitches present are D E A C\# (Fig. 32). This is a manipulation of the original miracle cell with a M3 added on instead of the $\mathrm{m} 3$ of appearances of the earlier movements (e.g., I/210; II/80). Noteworthy is the brightness that this M3 adds to the sonority. The collection contains all of the pitches of the A major triad, and the D can either be added to

114 Similar motion occurs at I/91-115. 
the wash of sound (creating a half-step dissonance with the $\mathrm{C \#}$ ), or can serve as a tonic pedal, generating a bright bitonal effect against the other pitches. Talbot makes use of both of these possibilities.

Figure 32. IV/53-61, piano reduction.

Text: S1-3: "laudabant te"

S5, A1: "by meadows of fern, by fields of rye."

B1-2: "By Fonfria del Camino."

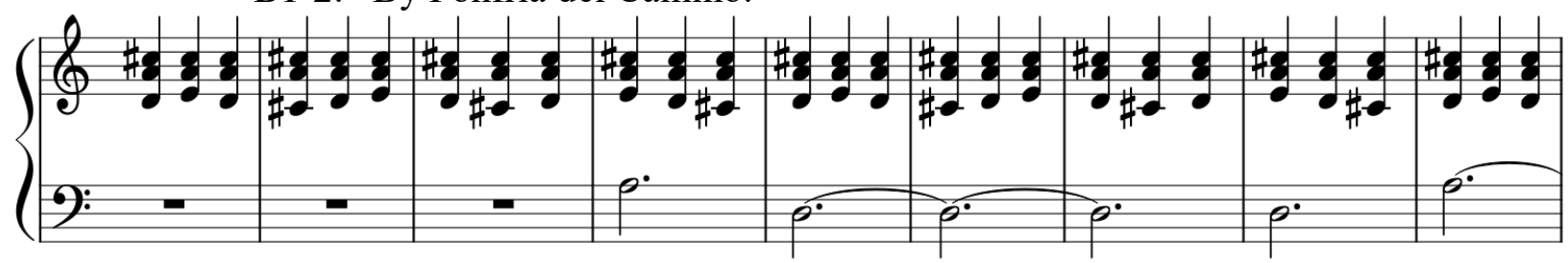

Standing alone as a wash of sound, the operative scale (if there is something more than just these four pitches), even the tonal center, is utterly ambiguous. The cantus firmus stands out, despite its slow motion. The text, in English as is usual for Pilgrims' Voice commentary, is quite reflective ("Towns are shadows the road leaves behind"). The generally joyous, even triumphant mood is created by the presence of major thirds and by the cantus firmus, which emphasizes major triads and perfect 5ths instead of the minor intervals and tritones of earlier movements. At m. 65, motion of the cantus firmus adds F\# to the color wash. Similar to the additive process applied in earlier movements, each slow change in the bass pitch here slightly alters the aural pitch collection, so that, e.g., when the bass moves to A in $\mathrm{m}$. 72, the F\# drops out.

The block of upper voices, which had been singing a M3, with C\# consistently the highest note, moves the top voice to $\mathrm{D}$ in $\mathrm{m} .89$ and then builds to $\mathrm{E}$ in $\mathrm{m} .93$ (Fig. 33). This expansion adds to the haunting and ethereal nature of the music. Then, from this height, a remarkable gradual stepwise descent takes place, first as the top voice moves from E down to A (m. 109) (where it remains on an upper voice pedal) and then continuing in A3-4, no longer in 
the top voice, all the way down another full octave (m. 137), where it rests against the rumbling $\mathrm{G \#}$ in the bass, pausing at a half cadence in $\mathrm{m} .148$. At the same time, beginning in $\mathrm{m} .113$ when the descending alto dips beneath the soprano pedal, B1-2 make an octave descent from F\# down to low G\#. At each downward step, the basses are separated by a diatonic 9th, sometimes major sometimes minor, from the altos above. After a reflective grand pause, the half cadence resolves down to F\# to begin the next section (m. 150).

Figure 33. IV/89-106, piano reduction.

Text: S1-3: "laudabant te"

S4-5, A1-2: "by meadows of fern, by fields of rye"

B1-2: "The road leaves behind./ It moves over the slate hills."
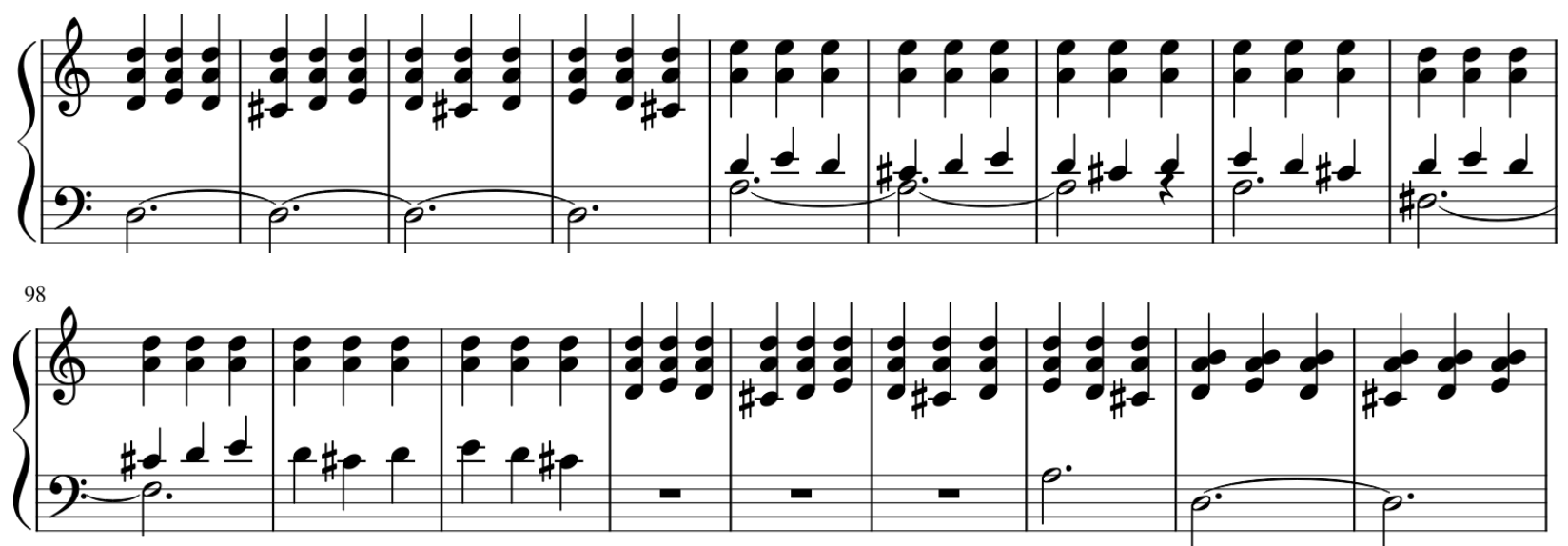

Meanwhile, by virtue of these descending lines, the harmonic landscape is altered, so that at 105, B is added to the collection (D E A C\# plus B). But B drops out almost immediately and then, presently, F\# and G\# are added (m. 113). We have now had, at one point or another, all of the pitches of the D Lydian scale (and nothing more). But Talbot doesn't offer the full richness of this scale all at once. Instead he teases us, showing us just a glimmer of light at first and then by turns revealing and concealing other colors until we are ready for the full glory of the scale (and the glory of something truly and beautifully sacred), which ultimately becomes audible in 
the long descending line. The theological conception as expressed in this section, with simpler and less dissonant language, is similar to the way Olivier Messiaen sought to portray the divine through increasingly rich and complex harmonies that overwhelm the senses and instill a sense of mystery and glory. And yet, in its simplicity, POM is able to convey a directness and authenticity perhaps more appropriate to the experience of an ingenuous pilgrim, untroubled by intricacies of advanced theology but seeking the divine presence that makes possible spiritual exaltation and renewal.

\section{B. Approaching Monte de Gozo and Descent to Santiago}

Measure 150 starts the final rapturous approach to Santiago itself. Starting on octave F\#s, the pilgrims first approach Monte de Gozo, an eagerly anticipated climb for pilgrims because the peak is the point on the Camino where, despite being some $5 \mathrm{~km}$ away, the spires of the Santiago cathedral may first be glimpsed. The unison expands outward in festive Lydian mode to a D major triad. Additive techniques are apparent here, in combination with harmony focusing on tertiary motion (Fig. 34). Talbot first leads us from the pitch F\# to a D major triad (m. 151); then starts again from F\# and reaches B minor (mm. 152-54); then starts a third time, passes through B minor and continues to expand the lowest and upper voices to arrival at $\mathrm{G}$ ( (instead of G\#) and a solid G major (mm. 156-62). 
Figure 34. IV/154-66, piano reduction.

Text: "From the foot of Monte de Gozo/To the summit of Monte de Gozo/The road climbs/Before the longed-for final descent/To Santiago
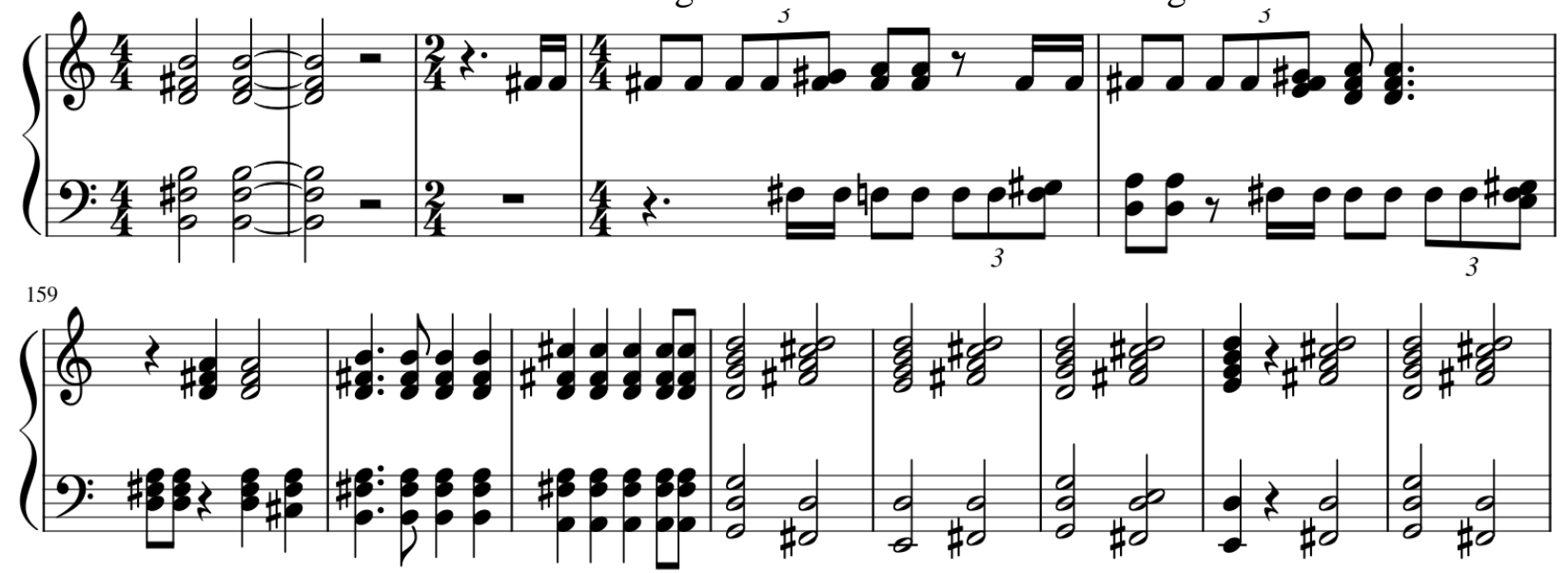

At the summit the chords become lush and functional, leading, again after a common tone assists modulation, to the Pilgrims' Hymn (m. 171). Just as in the initial statement at the outset of the piece, the chord is in second inversion, but now in a major key and piano dynamic. The hymn of praise takes the breath away with its simple, unadorned beauty, sounding utterly fresh and relaxed. Part of the freshness is its simplicity, but part, too, is only possible because of the arduous journey all the way from Roncesvalles to this point.

A new ostinato appears at $\mathrm{m} .182$ with large, soaring intervals establishing functional harmony on "esuseya" (Fig. 35). What a difference here from the extended ostinato of "Burgos" (II/80). Although the "Burgos" and "Santiago" ostinatos both include four half notes at a similar tempo, the ostinato here carries a series of pleasing functional chords. Large intervals afford a spaciousness. Beneath the ostinato on "eultreya" continues a D pedal. The pedal soon gives way in m. 189 to a joyful but subdued rhythmic "rapture" theme tossed, call and response style, between multiple voices in unison at a time, a stepwise theme which encompasses the miracle 
cell. As in other places in the work, the 10-beat theme interacts with the 8-beat ostinato to produce shifting harmonic color.

Figure 35. IV/182-89, piano reduction. Text: "eultreya esuseya."

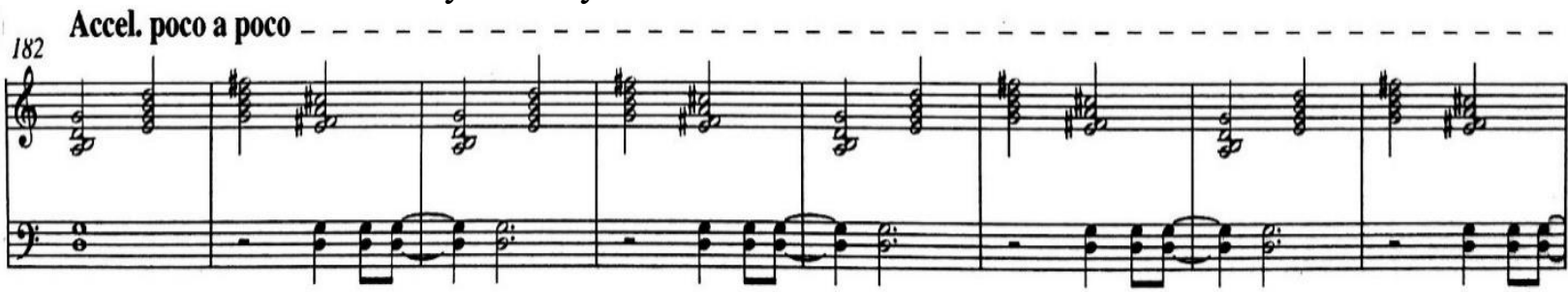

Additional lower voices gradually join the rapture theme until $\mathrm{m} .201$, where it erupts in all voices, now transposed up to D major (Fig. 36). But this is not just a transposition. As in "Leon" the transposition here does not move all sound blocks in the same direction. The rapture theme first appeared in the key of $\mathrm{G}$, circling the tonic and oscillating between a phrase on $\mathrm{G}$ and a phrase on E and arising beneath the essentially G-focused harmonic ostinato. At 201 the key is $\mathrm{D}$, but the first rapture phrase is on $\mathrm{A}$, the second on $\mathrm{F} \#$, accounting for a new brilliance and vibrancy in the theme. By circling the dominant here (instead of the tonic as at 190), the music is more expansive and joyous. The celebratory party has begun.

Figure 36. IV/201-04, piano reduction.

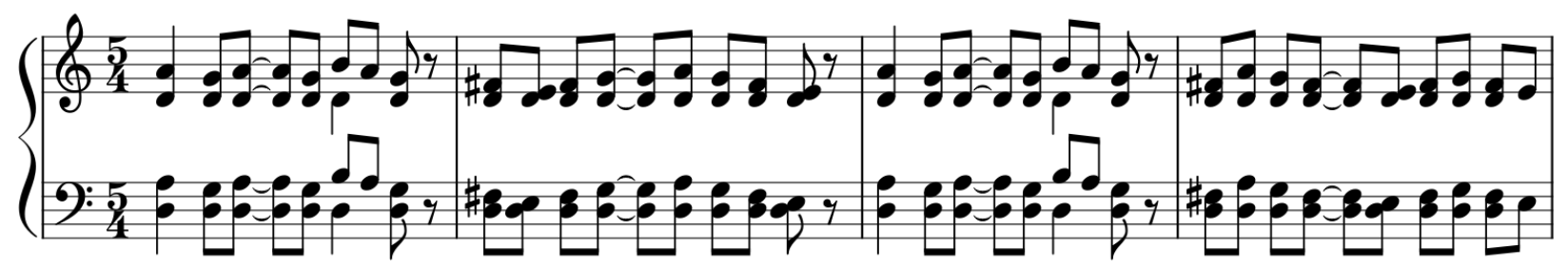

One might find a theme like this at a joyous, frolicking party in the pop-entertainment world - simple, straightforward harmony and a catchy, mostly stepwise melody. But now, for 100-plus measures until the return of the celebratory Pilgrims' Hymn at m. 337, Talbot adds 
variant after variant, with different motives and texts, as though different groups of pilgrims are all dancing, adding their own joyous ideas as they go. Changing textures, rhythms, rhythmic shout-outs to "Jacobo," breaking the theme down into smaller and smaller cells, adding in a slow-moving cantus firmus, and even a haunting return of the Pilgrims' Hymn.

In a notable manner, POM evokes the past in this section. During the $12^{\text {th }}$ century, life was not abruptly divided between the sacred and the secular in the way that it frequently is in modern western society. Talbot here blurs this distinction. In the midst of a holy pilgrimage to a sacred site, a seemingly out-of-place secular party erupts, complete with a purely secular text:

\author{
Ver redit optatum \\ Cum gaudio, \\ Flore decoratum \\ Purpureo; \\ Aves edunt cantus \\ Quam dulciter, \\ Cantus est amoenus \\ Totaliter.
}

Longed-for spring returns, with joy, adorned with shining

flowers. The birds sing so sweetly ... there is pleasant song on every side. $^{115}$

The text offers a clue to the seeming incongruity, as it is drawn from the $13^{\text {th }}$ century Carmina burana, and its lines, penned by monks, remind us that the secular need be no barrier to spiritual fulfillment and, indeed, the two can be intimately connected. Ensuing lines make the connection more clear: As multiple variants of the theme come fast and furious, one of them embraces profound thanks and enthusiasm for St. James (mm. 241ff.):

${ }^{115}$ POM omitted a line from the original text, revirescent nemus, "the woods burst into leaf." 
Jacobo dat parium

Omnis mundus gratis

Ob cuius remedium

Miles pietatis

Cunctorum presidium

Est ad vota satis.

The whole world freely gives thanks to James; through his sacrifice, he, the warrior of godliness, is a great defense to all through their prayers.

This text comes from the Dum pater familias of the Codex Calixtinus. Sacred and secular elements join together in this dance of praise and thanksgiving. ${ }^{116}$

At the outset (201), the joy of arrival so fills the air that a listener need not pay much attention to the key - it seems a self-evident and brilliant D major, long viewed as a joyful tonality. That conclusion would be premature however, because, in fact, at $201 \mathrm{D}$ Mixolydian is still a possibility as Talbot withholds the leading tone. We might have assumed D major at m. 217 when the tonal center shifts to G Lydian, which includes C\#. Talbot keeps swapping back and forth between variants of D and G. It is only at m. 249, when Talbot adds a new line of harmony that the brightness and zing of D major is confirmed. And perhaps that is where we always were. But in the exuberance of this growing celebration, Talbot makes us wait until we are truly ready for the full palette now including the particular joy of moving from leading tone to tonic. Moreover, once the leading tone appears, pilgrims seem unable to avoid it, breaking out with isolated eruptions of half-step motion from C\# to D, e.g., S2-3; T3-4 in mm. 242ff.

This raises again the question posed by Edward Cone as to whether the altered understanding causes the listener to reinterpret what was heard before (and thus conveys an

\footnotetext{
${ }^{116}$ For further discussion of sacred and secular elements of POM, see Meade, "Pilgrimage and Postminimalism in POM," 52-63.
} 
added appreciation for the structure of a beautiful work of art), or whether it is simply an added detail which opens a new vista on the music's meaning. In this case, Talbot's focus appears to be drama and psychology as these elements reside in a particular moment. While the pilgrims may at various times reflect back on earlier moments in the pilgrimage, structure of the composition is not itself the focus. Talbot seems rather to be allowing the enthusiasm of the moment to govern the level of immediate dramatic intensity.

The next bars present a contrast. At m. 253, some of the air goes out of the party as the lower voices shift to D minor, with altos entering a few bars later in D major. This major +minor duality is difficult to project audibly, both because of the darker key and because the F ' eighth notes are brief and occur in the middle of a complex texture, making it difficult to pull the ear to a new sonority. ${ }^{117}$ For similar reasons, the next measures, at 257, are also challenging. These bars return to $\mathrm{D}$ major in the upper voices, but maintain the briefest of $\mathrm{D}$ minor hints in the lowest voice. ${ }^{118}$ It seems likely that POM's foray into D minor helps to smooth the transition to the next section, at 262, which shifts to F minor in a tertiary harmonic shift.

Here another sacred verse in praise of St. James (from Dum pater familias) appears in the lower voices, joined (270) by A3-4 and T1-3 on a monochromatic but rhythmic reprise of the Carmina burana text. This text is soon shifted to upper voices singing in canon on the rapture theme. The Pilgrims' Hymn begins to appear in m. 296, isolated in a few voices which barely emerge from a highly rhythmic texture. And yet, even here, a dramatic difference from earlier pronouncements of the hymn becomes apparent. At the opening of POM, the second couplet of the hymn ("Eultreya ...") was a near monotone, with a miracle cell cadence offering a bit of

${ }^{117}$ Hints of D minor were present earlier, e.g., m. 241.

${ }^{118}$ For ideas about addressing these challenges in performance, see Chapter 6.D. 
color (I/17-18). Here this part of the hymn has been expanded by inclusion of large leaps reminiscent of the ostinato from $\mathrm{m}$. 182, with leaping fifths. Talbot has saved one of the few instances of non-step-wise motion in the entire piece for the dramatic final utterance of the hymn.

\section{Return of the Pilgrims' Hymn and Conclusion}

At m. 337, the Pilgrims' Hymn returns in full, adapted to incorporate the miracle cell in the first couplet and now with major chords (Fig. 37). For the first time, the Pilgrims' Hymn relies on root position triads. The transition brings a recollection of the tail of the Spanish Phrygian theme from "Roncesvalles," accompanying the return of the cantus firmus on the text:

At the Western edge of the world We pray for our sins to fall from us As chains from the limbs of penitents.

..

We have walked out of our lives To come to where the walls of heaven Are thin as a curtain, transparent as glass, -

Santiago, primus ex apostolis, Defender of pilgrims, warrior for truth, Take from our backs the burdens of this life,

What we have done, who we have been;

Take them as fire takes the cloth They cast into the sea at Finisterre. 
Figure 37. IV/337-342, piano reduction.

Text: "Herr Santiagu/Grot Sanctiagu/Eultreya esuseya."

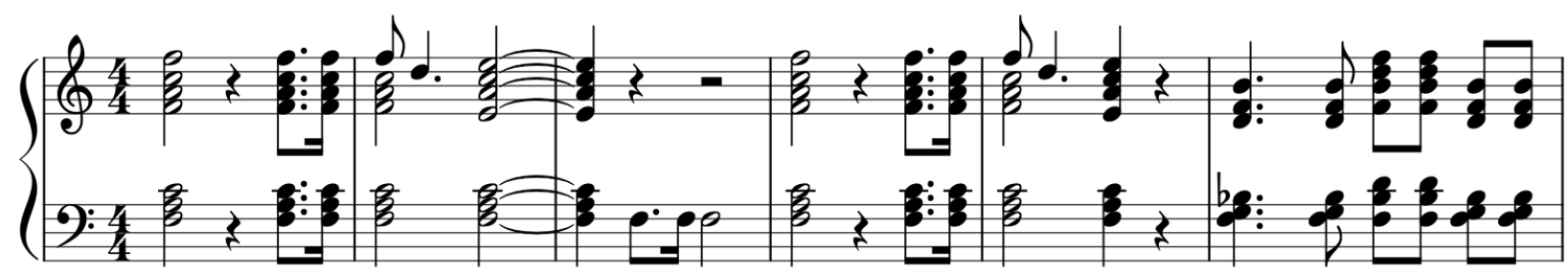

The last lines here refer to the tradition - after visiting the cathedral and completing the pilgrimage - of continuing an additional $85 \mathrm{~km}$ west to the western border of Spain. This at one time was thought to be the literal "end of the earth," Finisterre. In a symbol of the end of the old life, pilgrims traditionally discard an item of clothing at a fire on the beach. ${ }^{119}$

The pilgrims arrive at Finisterre firmly and serenely resting on D. Following a lengthy moment of silence, with their resolve affirmed, the glorious pilgrimage is over. But Talbot does not end there. Despite the party atmosphere of "Santiago" and the sheer joy of completing a monumental adventure, the piece does not conclude with a triumphant flourish. And, indeed, a pilgrimage is not like that, because the ultimate point of arrival, even where it includes profound spiritual awakening, is different for each individual: "Anyone making their way to a sacred place is journeying towards the opening of floodgates, towards a gateway to heaven. Exactly what that might mean for someone is, perhaps, difficult to encapsulate."120

It can be a challenge for a composer of principally non-functional harmony and relatively static music, to satisfactorily reach a conclusion to an extended work. As Bernard has observed referring to classic examples of minimalist music, "Though it is clear enough where such pieces

${ }^{119}$ Crouch, POM CD Liner Notes, 4.

${ }^{120}$ Meade, "Pilgrimage and Postminimalism in POM," 20; quoting Van Herck, "Pilgrimages: Being on and off the Right Track," 21. 
as I Am Sitting in a Room [by Alvin Lucier] or Reich's Come Out begin (or at least start), it is not at all clear that their endings are controlled by anything other than having run up against the limits of human perception. In a way, maybe they never do end." ${ }^{121}$ Moreover, without a strong pull of conflict between dominant and tonic a stirring final cadence is unlikely to be satisfying. One can sense Talbot struggling here, at just this moment, to determine how to bring the piece to a close. Fortunately for Talbot (and the work), he has selected his subject matter with great care, for the nature of pilgrimage, as, perhaps, with many meaningful experiences in life, is that it does not truly come to an end. Each individual, at the end of a significant journey, and perhaps continuing throughout life, will continue to mull over the experience and determine how best to incorporate it into the return to daily life.

It remains for pilgrims here to turn over the experience in their hearts and in their minds, and to determine, each individual for themselves, what the journey has meant for them and how they will carry it forward to alter their lives as they return from whence they came, each to their own place and in their own way. Pilgrims can decide this for themselves, of course, but fitting for a sacred pilgrimage is a final prayer to St. James and to God to "help us now and evermore." The rapture theme is unchanged harmonically, but appears in only a few voices, surrounded by a rich foundation of D major, allowing the theme and the feeling to rest and resonate. With the journey itself complete, and the connections with other pilgrims at an end, the rapture and the resonating D major continue, repeating to silence, as each singer exits the hall in different directions, still singing. All are changed by their experience, each in their own way. The seeking with which pilgrims began their pilgrimage is not over, but rather is changed in character. Each

${ }^{121}$ Bernard, "Minimalist Aesthetic," 1993, 121. 
continues to seek, and it remains for them to determine how to make the experience one of continued vitality in their daily lives as they leave a special and holy place.

In the same way, the ending can resonate with the listener, because audience members, having experienced musically the joys and hardships of the pilgrimage, can now leave the performing space in the same way that the singers have, determining, each for themselves, how the experience might inform their own lives. 


\section{CHAPTER 6: PERFORMANCE PLANNING AND PRACTICAL OBSERVATIONS FOR CONDUCTORS}

It is hoped that the previous chapters will prove valuable to conductors and performers seeking an understanding of meaning in POM, and that performance ideas will flow naturally from the score as analyzed. As one example, a conductor hearing a seemingly out of balance opening E minor chord need not fiddle with the underrepresented E or G: the balance was scored by the composer with a predominant B in mind, see supra at 22-23. Similarly, awareness of the long descending line in the sopranos, continuing through alto voices and then joined by basses (IV/93, see 69-70, supra), may lead to creative impulse from the performers, ranging from slight emphasis on the descent to none at all, permitting the existing scoring to adequately articulate the musical gesture. These are interpretive issues that are beyond the scope of this document, and this chapter is intended to address a limited number of more practical performance issues that choral ensembles are likely to face. ${ }^{122}$ First on this list is the selection of singers to be involved, as the work is virtuosic, with extreme ranges often sung at difficult dynamic levels. In addition, and for some of the same reasons, the selection of the performing venue is a significant consideration. We also investigate some of the specific demands, particularly those involving rhythm, interpretation, and intonation, as well as potential solutions. Finally, we explore some of the vocal demands of the score and potential solutions for the tremendous stamina required for performance.

${ }^{122}$ A more comprehensive exploration of this topic would benefit from interviews with conductors and performers who have undertaken performance as well as the composer. 


\section{$\underline{\text { A. Singer Selection }}$}

Performance of POM is a significant challenge for any ensemble, even the very finest. Thus, every performing aspect of the piece must be fully and carefully evaluated before programming the work. Of prime importance is the selection of the singers to be involved. The piece calls for 17 separate voice parts. POM was composed for the professional British choir Tenebrae, an ensemble with tremendous vocal clarity, bright, focused tone and clean, precise intonation. Composer Talbot clearly had this ensemble in mind, as POM calls for frequent tone clusters, balanced perfect intervals and striking dissonances. Care should be taken in selecting singers whose voices possess these characteristics, including a refined sense of pitch.

In the soprano section, the writing frequently calls for sustained soft singing in the upper part of the range. Clarity and ease in this register should be a significant consideration, as strained or overly loud singing by sopranos will throw off intonation or balance. A less focused or pointed sound may help singers in this part of their range. Even when singing at louder dynamic levels, the sopranos are frequently matched with basses singing at the very bottom of their range. It is extraordinarily difficult to find basses with adequate volume in these areas, so it is advisable to find sopranos who will not overpower the ensemble.

In the alto section, some of the writing calls for powerful, focused singing. The solo at $\mathrm{I} / 25$ is one such example. Tenebrae made use of male altos for much of this singing, a sensible idea. If male altos are not available, then altos who are able to adapt their vocal timbre to match the requirements of the piece would be advisable.

As mentioned, basses, especially parts 3 and 4, must be able to project significant volume at the extreme bottom of their range (including $\mathrm{A} 1$ at the opening and plenty of low $\mathrm{B}, \mathrm{Bb}$ and $\mathrm{C}$ 
throughout the rest of the piece). Projection of the bass voice can be helped in some respects by seeking additional "point" or "focus" to the sound in the lower parts of the range.

Some additional solutions to these problems are possible. POM calls for 17 individual vocal parts, but this does not necessarily mean that the parts need to be evenly distributed among the singers. Professional ensembles working primarily at one to a part have sometimes used additional singers to emphasize various points. For example, the Tenebrae $\mathrm{CD}$ recording lists only five sopranos to cover the five soprano parts, but lists a total of nine singers to cover the four bass parts. ${ }^{123}$ Larger ensembles can at least theoretically make similar proportional choices, although often these groups, e.g., conservatory-based ensembles, may nonetheless have difficulty finding adequate numbers of low basses.

\section{B. Venue and other Programming Considerations}

Just as important as the selection of singers is the choice of performing venue. Like the considerations for singers, the extreme ranges and unusual writing reveal special considerations in programming the piece. Much of the writing is intimate and quite exposed. Sometimes Talbot calls for high, delicate singing at a low dynamic level. The opening of "Leon," for example, has soprano voices maintaining motion around G5 in pianissimo for extended periods. The chorale in "Burgos," e.g., II/30, is another treacherous spot. Singers are quite vulnerable in these places, so a performing venue should enable singers to hear each other well. A relatively reverberant space will help with these concerns. Many concert halls tend to have drier acoustics - performance in such venues is certainly possible, but will certainly be more challenging. At the other extreme, the largest churches and cathedrals often have acoustics that are so reverberant that even with a large audience clarity and precision can be lost.

123 Tenebrae and Short, POM CD, 14. 
Selection of an appropriate venue will also help with accommodation of the stage directions provided in the score and may perhaps afford additional opportunities for theatrical engagement with the audience. The premiere, at St. Bartholomew the Great Church in London, saw singers move all over the space, taking advantage of differing acoustics at different places and enlivening the performance. Singers moved at various points to choir stalls beneath the organ loft, up to the gallery, and before the altar, as well as dispersing generally throughout the church at the final chanting exit. ${ }^{124}$

\section{Stamina}

For an extended work like POM, vocal and physical stamina should be another consideration. At 65 minutes, POM is not of a duration that from an audience perspective would typically require a break. However, the piece is unlike almost any other work in the repertoire in that it requires nearly uninterrupted singing by voices alone for the entire performance. The vocal demands are significant, as the piece contains a great deal of full singing, often at extremes of vocal range. While one voice or the other may rest as the textures unfold, the pauses for individual voice parts are generally brief.

Most performances of POM run straight through without a break. Most also usually place POM as the only piece on a program. ${ }^{125}$ Some have experimented with intermission, however. The Da Capo Chamber Choir from Ontario, for example, performed POM with an intermission

\footnotetext{
124 Breckenfield, "Path of Miracles Review."

${ }^{125}$ When Tenebrae re-released the 2005 POM they did it in conjunction with premiere of a separate work by Owain Park, Footsteps, and performed both works together on tour. Tenebrae Path of Miracles \& Footsteps - 15th Anniversary, 2017, youtube.com/watch?v=nEw83VsqXfg. Conspirare has performed the work both as a stand-alone concert and in conjunction with other pieces. Leibrock, "Path of Miracles Program Booklet, Conspirare"; Meade, "Pilgrimage and Postminimalism in POM," 88.
} 
following "Burgos." ${ }^{126}$ Such considerations might seem similar to those involved in other longish-but-not-too-long works. Mahler's Symphony No. 2 ("Resurrection"), 80 to 90 minutes, for example, is sometimes performed with intermission, though more often without. The composer apparently requested a pause after the second movement, an opening which encouraged the Arkansas Symphony to take an intermission there. ${ }^{127}$ And the Pittsburgh Symphony in 2017 took an intermission after the first movement, opening the concert with a shorter work. ${ }^{128}$ Other orchestras, including the New York Philharmonic, the Cleveland Orchestra and the Los Angeles Philharmonic, perhaps recognizing that the symphony represents a journey along the path of life, have recently performed the work as a stand-alone piece without intermission. ${ }^{129}$

Similarly, Ein Deutsches Requiem, at approximately 70 minutes, is almost never interrupted by intermission, though it is sometimes paired with a shorter work that allows for a reasonable place to break.

Like "Resurrection" and "German Requiem," POM is a journey both musically and spiritually. The dramatic unfolding of the narrative argues against an intermission that would break the dramatic momentum. A pilgrimage is, in some ways, a relentless challenge which tests pilgrims and forces them to suffer. Without taking the analogy too far, from a theatrical

${ }^{126}$ Da Capo Chamber Choir (Kitchener-Waterloo, Ontario), Da Capo Chamber Choir program booklet, March, 2013, 3.

${ }^{127}$ Don Anderson, "Mahler, Gustav - Symphony No. 2 in C Minor 'Resurrection," Arkansas Symphony, accessed April 2, 2020, arkansassymphony.org/mahler-gustav-symphony-no-2-in-cminor-resurrection\#close.

128 "Pittsburgh Symphony Orchestra BNY Mellon Grand Classics 2016-17 Program Booklet," May 2017, 26.

${ }^{129}$ Los Angeles Philharmonic, "Zubin Mehta Conducts Works by Mahler, Walt Disney Concert Hall," accessed April 2, 2020, laphil.com/events/performances/685/2020-01-04/mehtas-mahler; Cleveland Orchestra, "Cleveland Orchestra Program Book, October 4, 5, 6 Concerts," 2018, issuu.com/lpcpub/docs/tco-1819-week03/1; New York Philharmonic, "Jaap van Zweden Conducts Mahler's Resurrection Symphony," accessed April 2, 2020, nyphil.org/concertstickets/1920/jaap-van-zweden-conducts-mahlers-symphony-no-2. 
perspective, the audience should be able to deeply experience the intensity of the journey without stopping to get a drink, take a pit stop, talk with their friends, check their phones, etc. The artistic experience requires immersion, and part of the immersive process which is necessary for the audience to be carried along on this journey is continuation. Musical references from earlier movements recur in the final movement, references more readily grasped without a break. The piece is more effective if the audience has the entire journey in their minds and ears for the entire work. One solution employed by ODC Dance in a national tour involved moving singers and audience to different rooms in the performing venue between movements, an idea which both created a brief pause and at the same time created actual physical movement in accord with the theme of the work.

Another challenge on the stamina front is the physical challenge of standing for the length of performance. Some have suggested the possibility of performing from a seated position during "Leon," 130 but this brings its own set of challenges. It is true that the movement is generally of a subdued dynamic level. However, moments of more intense singing occur regularly (e.g., III/79; 119-26), along with extremely challenging singing, especially for sopranos, who frequently must maneuver up around Bb5. These characteristics make singing from a seated position vocally problematic.

More important, the mood of "Leon," while it does represent something of a relief during the long journey, is still one of engaged wonder and awe as the shimmering light of the cathedral is evoked throughout the movement. In this respect "Leon" is unlike "Wie lieblich" from the Brahms Requiem or "Mein teurer Heiland" from the St. John Passion, music of a subdued or

${ }^{130}$ Goolsby, "Pilgrimage Triptych," 41. 
ambient nature which is sometimes performed with the choir seated. ${ }^{131}$ The mood of "Leon" is not a feeling of rest and repose but rather, on the contrary, one of engagement, with renewed enthusiasm for a vigorous journey. It follows the weariness of "Burgos" and dramatically should, if anything, be presented with the increased energy of pilgrims who have started to become accustomed to the difficulties of the road. Practical challenges remain as well, including finding a place for the choir to sit, installing singers in and out of seats, and the visual impact of chairs when not being used. These are all matters that should be considered, particularly given POM's dramatic foundation. Because of these considerations, use of chairs is generally inadvisable in a POM performance, provided that singers are physically capable.

\section{Interpretation: Rhythm, Ancient Musical Styles and Tuning}

At a number of places in the piece, Talbot writes accents at unimportant points in the measure. At first sight, it appears that the score is seeking a syncopated emphasis. Often, however, what is really happening is that a rhythmic offset or augmentation is in play, creating a rhythm which is at odds with the time signature and perhaps with the other parts, but not necessarily with a syncopated edge to the sound. For example, at I/143, a new motive is introduced in S5 and B1, flowing hypnotically in a 5/4 meter. In m. 162, however, the meter changes to $3 / 4$ but the motive remains the same. Care should be taken to ensure that the accents are not excessive and that the 5/4 feel is maintained, especially where the first note of the motive appears to be syncopated (e.g., m. 163 (T4) and 165 (T3)) (Fig. 38).

131 Performances of "Resurrection" sometimes leave the choir seated until the final heroic exclamation, an effect offered more for dramatic impact than physical respite, as the choir has only about 15 minutes of singing in the entire work. 
Figure 38. I/160-167, A1-2, T3-4.

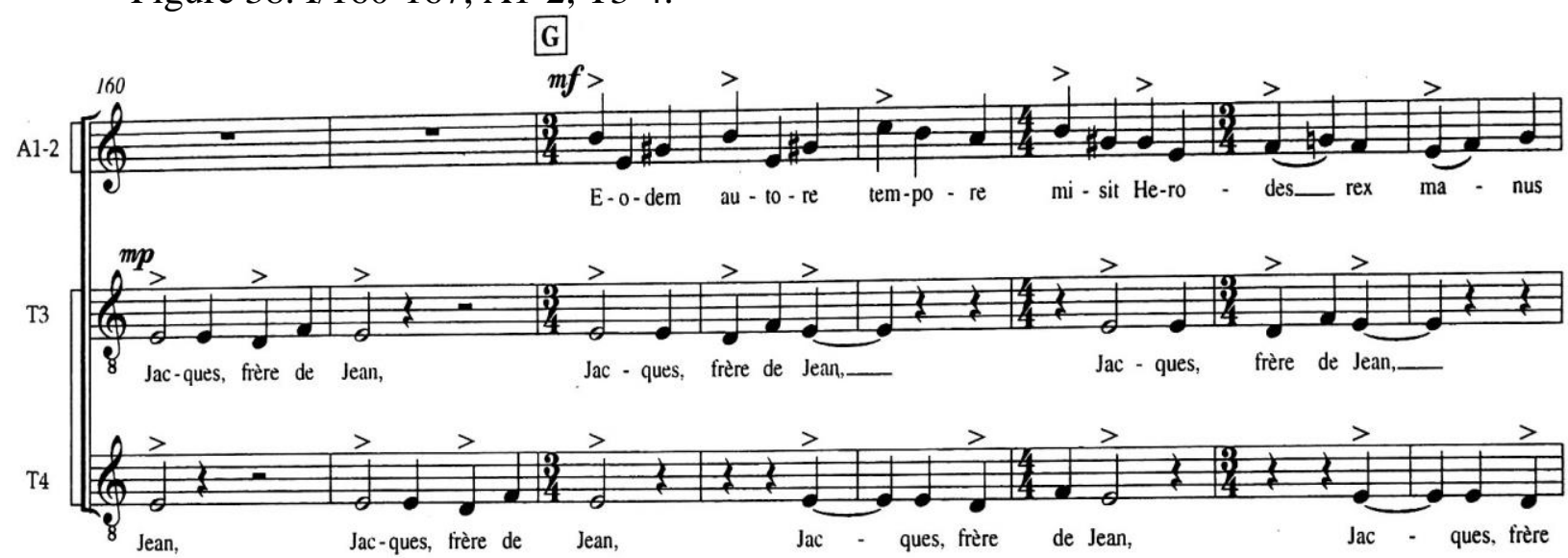

A similar example occurs at III/36, where the basic ostinato motive presents a rather challenging diminution which serves partially as an allargando within the meno mosso indication but which also sets up 4:3. That rhythmic pattern appears again at m. 44 and then directly against three quarter notes (A3-4) in the 3/4 time signature at $\mathrm{m}$. 51. The altos then sing their music in diminution as well, creating 2:3 in m. 53, against soprano quarter notes. (See Figures 20-22, supra.) The feeling should be of a gentle 4 against 3 and 2 against 3 rather than an angular syncopation.

As noted in the text, Talbot frequently evokes ancient musical styles in his writing. These ancient styles should not necessarily be performed as they would have been in earlier periods. Thus, for example, "Leon" begins with an ostinato figure in the upper voices and a cantus firmus in long, sustained notes in four lower voices. In traditional cantus firmus technique from the Medieval or Renaissance periods, the cantus firmus provided harmonic depth or foundation for more active melodic material in other voices. It was noticeable but not prominent in the overall texture. Cantus firmus in POM often serves the opposite role. At the opening of "Leon," the active material is essentially a color, a harmonic wash of sound, marked [pp] and sung more than an octave above the lower voices. The cantus firmus, marked [mp], should be more prominent. 
Moreover, although the pitches are long, they are not as long as one might typically find in the Medieval or Renaissance periods. As a result, the cantus firmus in performance should act as a slow but persistent melody, mimicking the pace of the journey, with its deliberate but still continuous forward progress. They should project more like a Bach chorale melody than a cantus firmus. See also IV/360. In general, the balance between the voice parts is not necessarily equal, as some voices should predominate and Talbot clearly marks the appropriate balance by use of differing dynamic markings.

Intonation is paramount in POM and extraordinarily difficult. The piece is entirely a cappella with the exception of a few bars of tuned bells in the first and last movements. The purity of open intervals as well as prominent use of tone clusters throughout demand acute and focused listening as well as absolute fealty to pitch. In addition, POM is not composed of independent, self-contained movements, as each movement is tonally related to the next. Several movements contain tricky half-step modulations. For example, "Roncesvalles" ends on Bb and "Burgos" starts on A minor (with Bb still an important part of the structure). "Leon" ends on D major and "Santiago" starts on C\# major. These half step transitions are destroyed if intonation is not preserved, and make it extraordinarily undesirable to re-pitch between movements. Instead, careful attention should be paid throughout the rehearsal process to flawless intonation. Finally, there are places where harmonic contrasts are subtle and care should be taken to ensure that they speak clearly. One example of such a spot is the minor key inflection beginning at IV/241. D minor arrives after an extended section of robust D major and G Mixolydian, and itself contains a surfeit of $\mathrm{C \#}$. The $\mathrm{F}$ appears in isolated eighth notes and can be inconspicuous, making the new mode difficult to hear. Special attention to the $\mathrm{F} \mapsto$ and recognition of its camouflaged position in the harmonic context will go far to make this contrast clear for the 
listener. With accomplished singers, awareness of the harmonic shift may be adequate to achieve the desired result. Specific additional solutions will likely vary from ensemble to ensemble. These could include ensuring that the vowel is pure for each of the Fts. Vowel purity is a key factor in choral unanimity and vocal projection; it is essential in this spot. Another potential solution is to address intonation by seeking a pitch somewhat on the "low" side in contrast to the F\#. Exaggerating the accents or lengthening the altered eighths slightly could be solutions as well, and are important to consider, but these adjustments could easily interfere with the overall texture. 


\section{CHAPTER 7: CONCLUSION: POM AS A DRAMATIC WORK}

The foregoing has sought to demonstrate at specific points along the way precisely how POM constitutes a powerful work of drama - theater, even. Evocation of the drama of the pilgrimage adventure is key both to understanding and performing POM. Talbot has employed a tremendous variety of compositional techniques. He has paid particular attention to half-step relationships throughout the piece, creating a unified conception that is nonetheless capable of adaptation in the service of different dramatic needs. He has expanded the half-step focus to create a "miracle cell" which appears throughout the work. The miracle cell helps to unify the work dramatically and is also capable of expansion and transformation in order to express a variety of different dramatic moods. Talbot uses additive and collage-like procedures to build drama and sometimes to express multiple emotions or ideas at once. Awareness of these techniques can help conductors and performers interpret the work and bring the drama more fully into the consciousness of the audience.

Moreover, POM is written in a musically driven dramatic form: musical expression provides meanings to the drama, as Kerman would say, that "enrich immeasurably, and enrich dramatically, and that cannot be presented in any other way." ${ }^{132}$ Certainly, given the limited plot and minimal action of the texts, it is impossible to envision POM without a musical component. But Talbot has done considerably more than create a satisfactory work out of a limited libretto. In point of fact, the text is not limited. Sparse, yes, but for POM, as noted, its sparseness can serve as an advantage. In the absence of particular characters or specific points of action, the audience may perhaps more readily identify with the drama and relate their own lives to the more generalized descriptions and events of the pilgrimage. That sparseness affords in this work a

\footnotetext{
${ }^{132}$ Kerman, Opera as Drama, 9.
} 
greater window for subtleties of musical expression, including the possibility for audience members to be truly affected and moved. 


\section{BIBLIOGRAPHY}

Anderson, Don. "Mahler, Gustav - Symphony No. 2 in C Minor 'Resurrection."” Arkansas Symphony. Accessed April 2, 2020. arkansassymphony.org/mahler-gustav-symphonyno-2-in-c-minor-resurrection\#close.

Barr, Alfred. Picasso: Fifty Years of His Art. New York: Museum of Modern Art, 1955.

Bauknecht, Sara. "Dancers to Make 'Path of Miracles' inside Trinity Cathedral." Pittsburgh Post-Gazette, November 6, 2019. post-gazette.com/ae/theater-dance/2019/11/06/Path-ofMiracles-ODC-Dance-Trinity-Cathedral-Pittsburgh-Dance-

Council/stories/201911060021.

Bernard, Jonathan W. "Minimalism, Postminimalism, and the Resurgence of Tonality in Recent American Music.” American Music 21, no. 1 (2003): 112-33. doi.org/10.2307/3250558. . "The Minimalist Aesthetic in the Plastic Arts and in Music." Perspectives of New Music 31, no. 1 (1993): 86. doi.org/10.2307/833043.

Breckenfield, Nick. "Joby Talbot - Path of Miracles." Classical Source. Accessed March 12, 2020. classicalsource.com/db_control/db_concert_review.php?id=2743.

Brown, Alan. "Galliard.” In Grove Music Online. Oxford University Press, 2001. doi.org/10.1093/gmo/9781561592630.article.10554.

Caruso, Michael. "Chestnut Hill Outdoor 'Courtroom' Thrilled by Lawsuits." Chestnut Hill Local Philadelphia PA, July 2, 2015. chestnuthilllocal.com/2015/07/02/chestnut-hilloutdoor-courtroom-thrilled-by-lawsuits/.

Cleveland Orchestra. "Cleveland Orchestra Program Book, October 4, 5, 6 Concerts," 2018. issuu.com/lpcpub/docs/tco-1819-week03/1.

Coffey, Thomas F., and Maryjane Dunn. The Miracles and Translatio of Saint James -- Books Two and Three of the Liber Sancti Jacobi. New York: Italica Press Medieval and Renaissance Texts Series, 2019.

Cone, Edward T. "Three Ways of Reading a Detective Story, or a Brahms Intermezzo.” The Georgia Review 31, no. 3 (1977): 554-74.

Corea, Chick. Chick Corea - La Fiesta. Accessed March 25, 2020. youtube.com/watch?v=8eVuwsimbtw.

Crouch, Gabriel. Path of Miracles Tenebrae CD Liner Notes. London: Signum Records, Ltd., 2006.

. "Tenebrae, Nigel Short, Artistic Director." Princeton University Concerts, March 15, 2018. princetonuniversityconcerts.org/docs/1718_Tenebrae_Program_Print.pdf.

D'Emilio, James. "The Building and the Pilgrims' Guide." In The Codex Calixtinus and the Shrine of St. James, edited by John Williams and Alison Stones, 185-206. Tübingen: Narr, 1992.

Da Capo Chamber Choir. "Da Capo Chamber Choir Program Booklet," March 2013. dacapochamberchoir.ca/wp-content/uploads/2013/09/program-Mar2013.pdf.

Denney, Alan. “Ours to See: Emerging Trends in Today's Choral Compositions." Choral Journal 60, no. 3 (October 2019): 8-20.

Everist, Mark. French Motets in the Thirteenth Century: Music, Poetry and Genre. Cambridge, UK: Cambridge University Press, 2004.

Francom, Jeffrey. "Crane Concert Choir Program, April 20, 2017." Potsdam.edu. Accessed February 9, 2020. potsdam.edu/sites/default/files/Path\%20of\%20Miracles\%20program\%204\%2020\%2017 \%20\%20REVISED\%20FORMAT.pdf. 
Galbraith, Susan. "Spoleto Festival USA 2019: Path of Miracles by The Westminster Choir." DC Theatre Scene, May 30, 2019. dctheatrescene.com/2019/05/30/spoleto-festival-usa-2019path-of-miracles-by-the-westminster-choir/.

Garcia, Alfonso. The Road to Santiago. Edited by Vincent Pastor. León: Edilesa, 1999.

Goolsby, Jeffery H. “A Pilgrimage Triptych: A Conductor's Guide to Three Contemporary Choral Works." DMA diss., Texas Tech University, 2018. ttuir.tdl.org/bitstream/handle/2346/82110/Goolsby_DissertationReview.pdf?sequence=8\&is Allowed=y.

Gradante, William. "Guajira.” In Grove Music Online. Oxford University Press, 2001. doi-org /10.1093/gmo/9781561592630.article.11889.

Grout, Donald Jay. A Short History of Opera. 3rd Edition. New York: Columbia University Press, 1988.

Helmer, Paul. The Mass of St. James: Solemn Mass for the Feast of the Passion of St. James of Compostela according to the Codex Calixtinus. Ottawa, Canada: Institute of Mediaeval Music, 1988.

Hoffman, Herbert H. Hoffman's Index to Poetry: European and Latin American Poetry in Anthologies. Scarecrow Press, 1985.

Hojnacki, Tom. Introducing the Spanish Phrygian Scale, Berklee Online. Accessed March 25, 2020. youtube.com/watch?v=yRggh1XXZZI.

Katz, Israel. "Flamenco." In Grove Music Online. Oxford University Press, 2001. doiorg/10.1093/gmo/9781561592630.article.09780.

Kerman, Joseph. Opera as Drama. New York: Alfred A. Knopf, 1956.

Knauss, Jessica. "Villalcázar de Sirga: The Miracle Worker." Jessica Knauss, Spain, Middle Ages (blog), January 27, 2019. jessicaknauss.blogspot.com/2019/01/villalcazar-de-sirgamiracle-worker.html.

— "Villalcázar de Sirga: The Miracles." Jessica Knauss, Spain, Middle Ages (blog), January 22, 2019. jessicaknauss.blogspot.com/2019/01/villalcazar-de-sirgamiracles.html.

Leibrock, Eric. "Path of Miracles Program Booklet, Conspirare," January 2014. conspirare.org/wp-content/uploads/path-of-miracles-program-booklet.pdf.

Lilson, Jo. "Path of Miracles (Sydney Philharmonia Choirs)." Limelight (blog). Accessed March 12, 2020. limelightmagazine.com.au/reviews/path-of-miracles-sydney-philharmoniachoirs/.

Longo, Kathryn. Review of Joby Talbot: Path of Miracles, by Craig Hella Johnson. The Choral Journal 56, no. 11 (July 2016): 79.

Los Angeles Philharmonic. "Zubin Mehta Conducts Works by Mahler, Walt Disney Concert Hall.” Accessed April 2, 2020. laphil.com/events/performances/685/2020-01-04/mehtasmahler.

Meade, Joy Elizabeth. "Pilgrimage and Postminimalism in Joby Talbot's Path of Miracles." DMA diss., University of Georgia, 2016. athenaeum.libs.uga.edu/handle/10724/36263.

Melczer, William. The Pilgrim's Guide to Santiago de Compostela. New York: Italica Press, 1993.

Monk, Meredith. "Monk: Dolmen Music.” Youtube, July 29, 2018. youtube.com/watch?v=DVrsuMWX7-Y. 
New York Philharmonic. "Jaap van Zweden Conducts Mahler's Resurrection Symphony." Accessed April 2, 2020. nyphil.org/concerts-tickets/1920/jaap-van-zweden-conductsmahlers-symphony-no-2.

"ODC/Dance 'Path of Miracles' The Most Active Center for Contemporary Dance on the West Coast." Accessed March 23, 2020. odc.dance/path.

Olson, Matthew. The Singers: Path of Miracles by Joby Talbot. Carleton College, MN, 2018. youtube. $\mathrm{com} / \mathrm{watch}$ ? $\mathrm{v}=2 \mathrm{f} 3 \mathrm{JW} 7 \mathrm{tDNtY} \& \mathrm{t}=902 \mathrm{~s}$.

"Pittsburgh Symphony Orchestra BNY Mellon Grand Classics 2016-17 Program Booklet," May 2017.

Savarese, Daniel. "Dum Pater Familias (The Song of Compostela) (Anonymous) Savarese.Org." Accessed March 12, 2020. savarese.org/music/DumPaterFamilias.html.

Shearer-Dirié, Debra. "Fusion Vocal Ensemble Program, Path of Miracles," April 2017. fusionvocalensemble.org/uploads/2/1/2/1/21215054/fusion_programme_path_of_miracle s_march-april_2017.pdf.

Simeone, Nigel. Leonard Bernstein: West Side Story. London: Routledge, 2017.

Singul, Francisco. Historia Cultural Do Camiño de Santiago. Vigo, Spain: Editorial Galaxia, 1999.

Stanton, Edward F. The Road of Stars to Santiago. Lexington: The University Press of Kentucky, 1994.

Talbot, Joby. “About.” Joby Talbot. Accessed March 23, 2020. jobytalbot.com/about.

—. Path of Miracles. London: Chester Music, 2005. "Selected Works." Joby Talbot. Accessed March 25, 2020. jobytalbot.com/works.

Tenebrae - Path of Miracles \& Footsteps - 15th Anniversary, 2017. youtube.com/watch? $=$ nEw83VsqXfg.

Tenebrae, and Nigel Short. Joby Talbot: Path of Miracles. CD Recording. London: Signum Records, Ltd. SIGCD078, 2006.

Turner, Victor, and Edith Turner. Image and Pilgrimage in Christian Culture. New York: Columbia University Press, 1978.

Van Herck, Walter. "Pilgrimages: Being on and off the Right Track." In Sacred Places: Pilgrimages in Judaism, Christianity and Islam, edited by Chris de Lauwer, 14-21. Antwerp: BAI for the Museum aan de Stroom, 2014.

Williams, John, and Alison Stones, eds. The Codex Calixtinus and the Shrine of St. James. Jakobus-Studien 3. Tübingen: Narr, 1992. 


\section{APPENDIX: SELECTED PERFORMANCES}

Some representative ensembles which have performed POM include:

Conspirare. Eric Leibrock, "Path of Miracles Program Booklet, Conspirare," January 2014, conspirare.org/wp-content/uploads/path-of-miracles-programbooklet.pdf.; Kathryn Longo, review of Joby Talbot: Path of Miracles, by Craig Hella Johnson, The Choral Journal 56, no. 11 (July 2016): 79.

Crane Concert Choir. Jeffrey Francom, "Crane Concert Choir Program, April 20, 2017," Potsdam.edu, accessed February 9, 2020, potsdam.edu/sites/default/files/Path\%20of\%20Miracles\%20program\%204\%2020 \%2017\%20\%20REVISED\%20FORMAT.pdf.

The Crossing. Michael Caruso, "Chestnut Hill Outdoor 'Courtroom' Thrilled by Lawsuits,” Chestnut Hill Local Philadelphia PA, July 2, 2015, chestnuthilllocal.com/2015/07/02/chestnut-hill-outdoor-courtroom-thrilled-bylawsuits/.

Da Capo Chamber Choir (Kitchener-Waterloo, Ontario). "Da Capo Chamber Choir Program Booklet," Da Capo Chamber Choir, March 2013, dacapochamberchoir.ca/wp-content/uploads/2013/09/program-Mar2013.pdf.

Fusion Vocal Ensemble (Toowoomba, Australia). Debra Shearer-Dirié, "Fusion Vocal Ensemble Program, Path of Miracles," April 2017, 1, fusionvocalensemble.org/uploads/2/1/2/1/21215054/fusion_programme_path_of_ miracles_march-april_2017.pdf.

ODC Dance. "ODC/Dance 'Path of Miracles' The Most Active Center for Contemporary Dance on the West Coast," accessed March 23, 2020, odc.dance/path; Sara Bauknecht, "Dancers to Make 'Path of Miracles' inside Trinity Cathedral," Pittsburgh Post-Gazette, November 6, 2019, postgazette.com/ae/theater-dance/2019/11/06/Path-of-Miracles-ODC-Dance-TrinityCathedral-Pittsburgh-Dance-Council/stories/201911060021.

The Singers (Minneapolis). Matthew Olson, The Singers: Path of Miracles by Joby Talbot (Carleton College, MN, 2018), youtube.com/watch?v=2f3JW7tDNtY\&t=902s.

Sydney Philharmonia Chorus. Jo Lilson, "Path of Miracles (Sydney Philharmonia Choirs)," Limelight (blog), accessed March 12, 2020, limelightmagazine.com.au/reviews/path-of-miracles-sydney-philharmoniachoirs/.

Tenebrae. Tenebrae and Nigel Short, Joby Talbot: Path of Miracles, CD Recording (London: Signum Records, Ltd. SIGCD078, 2006); Gabriel Crouch, 
"Tenebrae, Nigel Short, Artistic Director," Princeton University Concerts, March 15,2018 ,

princetonuniversityconcerts.org/docs/1718_Tenebrae_Program_Print.pdf;

Westminster Choir. Susan Galbraith, "Spoleto Festival USA 2019: Path of Miracles by The Westminster Choir," DC Theatre Scene, May 30, 2019, dctheatrescene.com/2019/05/30/spoleto-festival-usa-2019-path-of-miracles-bythe-westminster-choir/. 